McKay, R.M., De Santis, L., Kulhanek, D.K., and the Expedition 374 Scientists

Proceedings of the International Ocean Discovery Program Volume 374

publications.iodp.org

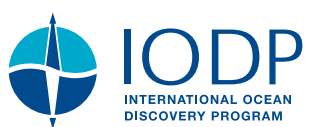

https://doi.org/10.14379/iodp.proc.374.101.2019

Check for updates

Contents

\section{Expedition 374 summary ${ }^{1}$}

R.M. McKay, L. De Santis, D.K. Kulhanek, J.L. Ash, F. Beny, I.M. Browne,

G. Cortese, I.M. Cordeiro de Sousa, J.P. Dodd, O.M. Esper, J.A. Gales,

D.M. Harwood, S. Ishino, B.A. Keisling, S. Kim, S. Kim, J.S. Laberg, R.M. Leckie,

J. Müller, M.O. Patterson, B.W. Romans, O.E. Romero, F. Sangiorgi, O. Seki,

A.E. Shevenell, S.M. Singh, S.T. Sugisaki, T. van de Flierdt, T.E. van Peer, W. Xiao, and Z. Xiong ${ }^{2}$

Keywords: International Ocean Discovery Program, IODP, JOIDES Resolution, Expedition 374, Site U1521, Site U1522, Site U1523, Site U1524, Site U1525, Ross Sea, West Antarctic, ice sheet history, sea ice, Miocene, Pliocene, Quaternary, Antarctic Bottom Water, Antarctic water masses, turbidites, contourites, glaciomarine sediments, subglacial sediments, ice-rafted debris, paleobathymetry, seismic stratigraphy, paleoclimate, paleoceanography
1 Abstract

2 Introduction

9 Scientific objectives

11 Site summaries

29 Expedition synthesis and preliminary scientific assessment

32 Science objectives achieved during Expedition 374

36 References

\begin{abstract}
The marine-based West Antarctic Ice Sheet (WAIS) is currently locally retreating because of shifting wind-driven oceanic currents that transport warm waters toward the ice margin, resulting in ice shelf thinning and accelerated mass loss. Previous results from geologic drilling on Antarctica's continental margins show significant variability in ice sheet extent during the late Neogene and Quaternary. Climate and ice sheet models indicate a fundamental role for oceanic heat in controlling ice sheet variability over at least the past $20 \mathrm{My}$. Although evidence for past ice sheet variability is available from ice-proximal marine settings, sedimentary sequences from the continental shelf and rise are required to evaluate the extent of past ice sheet variability and the associated forcings and feedbacks. International Ocean Discovery Program Expedition 374 drilled a latitudinal and depth transect of five sites from the outer continental shelf to rise in the central Ross Sea to resolve Neogene and Quaternary relationships between climatic and oceanic change and WAIS evolution. The Ross Sea was targeted because numerical ice sheet models indicate that this sector of Antarctica responds sensitively to changes in ocean heat flux. Expedition 374 was designed for optimal data-model integration to enable an improved understanding of Antarctic Ice Sheet (AIS) mass balance during warmer-than-present climates (e.g., the Pleistocene "super interglacials," the mid-Pliocene, and the Miocene Climatic Optimum). The principal goals of Expedition 374 were to
\end{abstract}

- Evaluate the contribution of West Antarctica to far-field ice volume and sea level estimates;
- Reconstruct ice-proximal oceanic and atmospheric temperatures to quantify past polar amplification;

- Assess the role of oceanic forcing (e.g., temperature and sea level) on AIS variability;

- Identify the sensitivity of the AIS to Earth's orbital configuration under a variety of climate boundary conditions; and

- Reconstruct Ross Sea paleobathymetry to examine relationships between seafloor geometry, ice sheet variability, and global climate.

To achieve these objectives, postcruise studies will

- Use data and models to reconcile intervals of maximum Neogene and Quaternary ice advance and retreat with far-field records of eustatic sea level;

- Reconstruct past changes in oceanic and atmospheric temperatures using a multiproxy approach;

- Reconstruct Neogene and Quaternary sea ice margin fluctuations and correlate these records to existing inner continental shelf records;

- Examine relationships among WAIS variability, Earth's orbital configuration, oceanic temperature and circulation, and atmospheric $p \mathrm{CO}_{2}$; and

- Constrain the timing of Ross Sea continental shelf overdeepening and assess its impact on Neogene and Quaternary ice dynamics.

Expedition 374 departed from Lyttelton, New Zealand, in January 2018 and returned in March 2018. We recovered $1292.70 \mathrm{~m}$ of

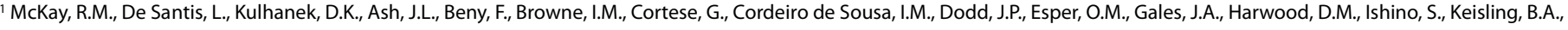
Kim, S., Kim, S., Laberg, J.S., Leckie, R.M., Müller, J., Patterson, M.O., Romans, B.W., Romero, O.E., Sangiorgi, F., Seki, O., Shevenell, A.E., Singh, S.M., Sugisaki, S.T., van de Flierdt, T., van Peer, T.E., Xiao, W., and Xiong, Z., 2019. Expedition 374 summary. In McKay, R.M., De Santis, L., Kulhanek, D.K., and the Expedition 374 Scientists, Ross Sea West Antarctic Ice Sheet History. Proceedings of the International Ocean Discovery Program, 374: College Station, TX (International Ocean Discovery Program). https://doi.org/10.14379/iodp.proc.374.101.2019 2 Expedition 374 Scientists' affiliations.

MS 374-101: Published 10 August 2019

This work is distributed under the Creative Commons Attribution 4.0 International (CC BY 4.0) license. (cc)B BY 
high-quality core from five sites spanning the early Miocene to late Quaternary. Three sites were cored on the continental shelf (Sites U1521, U1522, and U1523). At Site U1521, we cored a $650 \mathrm{~m}$ thick sequence of interbedded diamictite and diatom-rich mudstone penetrating seismic Ross Sea Unconformity 4 (RSU4). The depositional reconstructions of past glacial and open-marine conditions at this site will provide unprecedented insight into environmental change on the Antarctic continental shelf during the late early and middle Miocene. At Site U1522, we cored a discontinuous late Miocene to Pleistocene sequence of glacial and glaciomarine strata from the outer shelf with the primary objective of penetrating and dating RSU3, which is interpreted to reflect the first continental shelfwide expansion of East and West Antarctic ice streams. Site U1523, located on the outer continental shelf, targeted a sediment drift beneath the westward-flowing Antarctic Slope Current (ASC) to test the hypothesis that changes in ASC vigor regulate ocean heat flux onto the continental shelf and thus ice sheet mass balance.

We also cored two sites on the continental rise and slope. At Site U1524, we recovered a Plio-Pleistocene sedimentary sequence from the levee of the Hillary Canyon, one of the largest conduits of Antarctic Bottom Water from the continental shelf to the abyssal ocean. Site U1524 was designed to penetrate into middle Miocene and older strata, but coring was initially interrupted by drifting sea ice that forced us to abandon coring in Hole U1524A at $399.5 \mathrm{~m}$ drilling depth below seafloor (DSF). We moved to a nearby alternate site on the continental slope (Site U1525) to core a single hole designed to complement the record at Site U1524. We returned to Site U1524 after the sea ice cleared and cored Hole U1524C with the rotary core barrel system with the intention of reaching the target depth of $1000 \mathrm{~m}$ DSF. However, we were forced to terminate Hole U1524C at $441.9 \mathrm{~m}$ DSF because of a mechanical failure with the vessel that resulted in termination of all drilling operations and forced us to return to Lyttelton 16 days earlier than scheduled. The loss of $39 \%$ of our operational days significantly impacted our ability to achieve all Expedition 374 objectives. In particular, we were not able to recover continuous middle Miocene sequences from the continental rise designed to complement the discontinuous record from continental shelf Site U1521. The mechanical failure also meant we could not recover cores from proposed Site RSCR-19A, which was targeted to obtain a high-fidelity, continuous record of upper Neogene and Quaternary pelagic/hemipelagic sedimentation. Despite our failure to recover a continental shelf-to-rise Miocene transect, records from Sites U1522, U1524, and U1525 and legacy cores from the Antarctic Geological Drilling Project (ANDRILL) can be integrated to develop a shelf-to-rise Plio-Pleistocene transect.

\section{Introduction}

International Ocean Discovery Program (IODP) Expedition 374 recovered Ross Sea outer continental shelf-to-rise sedimentary sequences of Neogene to Quaternary Antarctic Ice Sheet (AIS) evolution that will improve understanding of climate forcings/feedbacks on past ice sheet variability. These sequences, in combination with model sensitivity tests, tectonic considerations, and the well-developed seismic stratigraphic framework of the Ross Sea, will enable researchers to determine the contribution of Antarctic ice volume to far-field Neogene sea level variations (20-60 m) (cf., Miller et al., 2005, 2012; Kominz et al., 2008; Naish and Wilson, 2009; John et al., 2011) (Figures F1, F2, F3). These sequences, recovered from an area of demonstrated climate sensitivity (Figure F4), allow for improved understanding of ocean-ice sheet interactions on orbital to millionyear timescales.

The onset of the Neogene (23 Ma; Oligocene/Miocene [O/M] boundary) is associated with a transient, abrupt increase in Antarctic ice volume attributed to changes in Earth's orbital parameters (Zachos et al., 1997; Naish et al., 2001) and declining atmospheric $\mathrm{CO}_{2}$ (Figure F1) (Pagani et al., 2005; Foster and Rohling, 2013). Following the relatively cool early Miocene, proxy records indicate a period of sustained global warmth (on average $\sim 3^{\circ} \mathrm{C}$ warmer than present; Flower and Kennett, 1994; You et al., 2009) and a significant carbon cycle reorganization (e.g., Vincent and Berger, 1985; Foster et al., 2012) referred to as the Miocene Climatic Optimum (MCO; 17-14.5 Ma) (Flower and Kennett, 1994; Shevenell et al., 2004). During the MCO, significant polar amplification of temperature occurred (Shevenell et al., 2004, 2008; Lewis et al., 2008; Warny et al., 2009; Feakins et al., 2012; Sangiorgi et al., 2018), the origins of which are unknown. Immediately following the MCO, Antarctic ice growth and cooling, termed the Middle Miocene Climate Transition (MMCT; 14.2-13.8 Ma), is inferred from both deep-sea benthic foraminifer $\delta^{18} \mathrm{O}$ records and ice-proximal data (Figure F1B) (Kennett, 1977; Flower and Kennett, 1994; Zachos et al., 2001; Shevenell et al., 2004, 2008; Holbourn et al., 2007; Cramer et al., 2009; John et al., 2011; Pierce et al., 2017; Sangiorgi et al., 2018). However, far-field evidence suggests ice growth may have initiated during the MCO (Shevenell et al., 2004, 2008). The MMCT resulted in the loss of the Antarctic tundra vegetation at high elevations in the Transantarctic Mountains (Lewis et al., 2008). Although ice expansion has traditionally been inferred in East Antarctica, Ross Sea seismic evidence also suggests West Antarctic Ice Sheet (WAIS) expansion during the MMCT (Bart, 2003). However, the timing of the Ross Sea event, WAIS development, and forcings and feedbacks involved in the MMCT remain enigmatic, as does the subsequent climate and ice sheet history of the relatively late Miocene (e.g., Kennett, 1977; De Santis et al., 1995; Zachos et al., 2001; Ohneiser et al., 2015; Herbert et al., 2016). During the mid-Pliocene, global sea levels are estimated to have been $\sim 20 \pm 10 \mathrm{~m}$ above present-day levels, indicating a reduction/collapse of both the Greenland Ice Sheet and the WAIS (Miller et al., 2012). Ice-proximal sedimentary facies indicate WAIS advances and retreats from the early Pliocene to $\sim 1.0$ Ma (Figure F4) (Naish et al., 2009). However, equivocal evidence exists for WAIS collapse as recently as the last interglacial (Scherer et al., 1998; Kopp et al., 2009; Naish et al., 2009; McKay et al., 2012b; Dahl-Jensen et al., 2013; Kingslake et al., 2018). Thus, obtaining late Pleistocene paleoclimate records from the Ross Sea was a high priority for Expedition 374.

\section{Background}

\section{Oceanographic setting}

At present, the abyssal ocean is filled with cold, dense seawater produced in the large polynyas of the Weddell and Ross Seas (Orsi et al., 1999; Johnson, 2008). Thus, regional changes in temperature and/or meltwater input to the Ross Sea are expected to have a pronounced impact on global meridional overturning circulation (Jacobs et al., 2002; Orsi and Wiederwohl, 2009; Purkey and Johnson, 2010). Over the past 40 y, Ross Sea-derived Antarctic Bottom Water $(\mathrm{AABW})$ has freshened as a result of increased meltwater input to the Amundsen and Bellingshausen Seas from melting ice shelves/glacial systems (Jacobs et al., 2002, 2011; Johnson, 2008; Jacobs and Giulivi, 2010; Purkey and Johnson, 2010, 2012). 
Figure F1. Data reconstructions. A. Left: compilation of atmospheric $\mathrm{CO}_{2}$ proxies throughout the Cenozoic. Proxy methods are from Masson-Delmotte et al. (2013). Right: "best and worst case" representative concentration pathways (RCPs) for historic and future atmospheric $\mathrm{CO}_{2}$ emissions (Meinshausen et al., 2011). $P D=$ present day. B. Composite deep-ocean benthic $\delta^{18} \mathrm{O}$ record for the last $65 \mathrm{My}$ that represents a combined signal of global ice volume and deepocean temperature after $35 \mathrm{Ma}$ (Zachos et al., 2001). C. Long-term trend in deep-sea temperature through the Cenozoic based on removal of the ice volume component of the benthic $\delta^{18} \mathrm{O}$ record using sequence stratigraphic records (black line with gray uncertainty band) and $\mathrm{Mg} / \mathrm{Ca}$ ratio estimates of deep-sea temperatures (Cramer et al., 2009) and scaled $\delta^{18} \mathrm{O}$ for the past $10 \mathrm{My}$ (Miller et al., 2011). D. Reconstruction of sea level lowstands (black lines) with minimum uncertainty ranges (gray shading) and smoothed highstand trend (black dotted line) using sequence stratigraphy for the New Jersey margin. Sea levels $>70 \mathrm{~m}$ imply a significant tectonic component to this record, particularly prior to the Oligocene (Kominz et al., 2008). Figure reproduced from McKay et al. (2017).

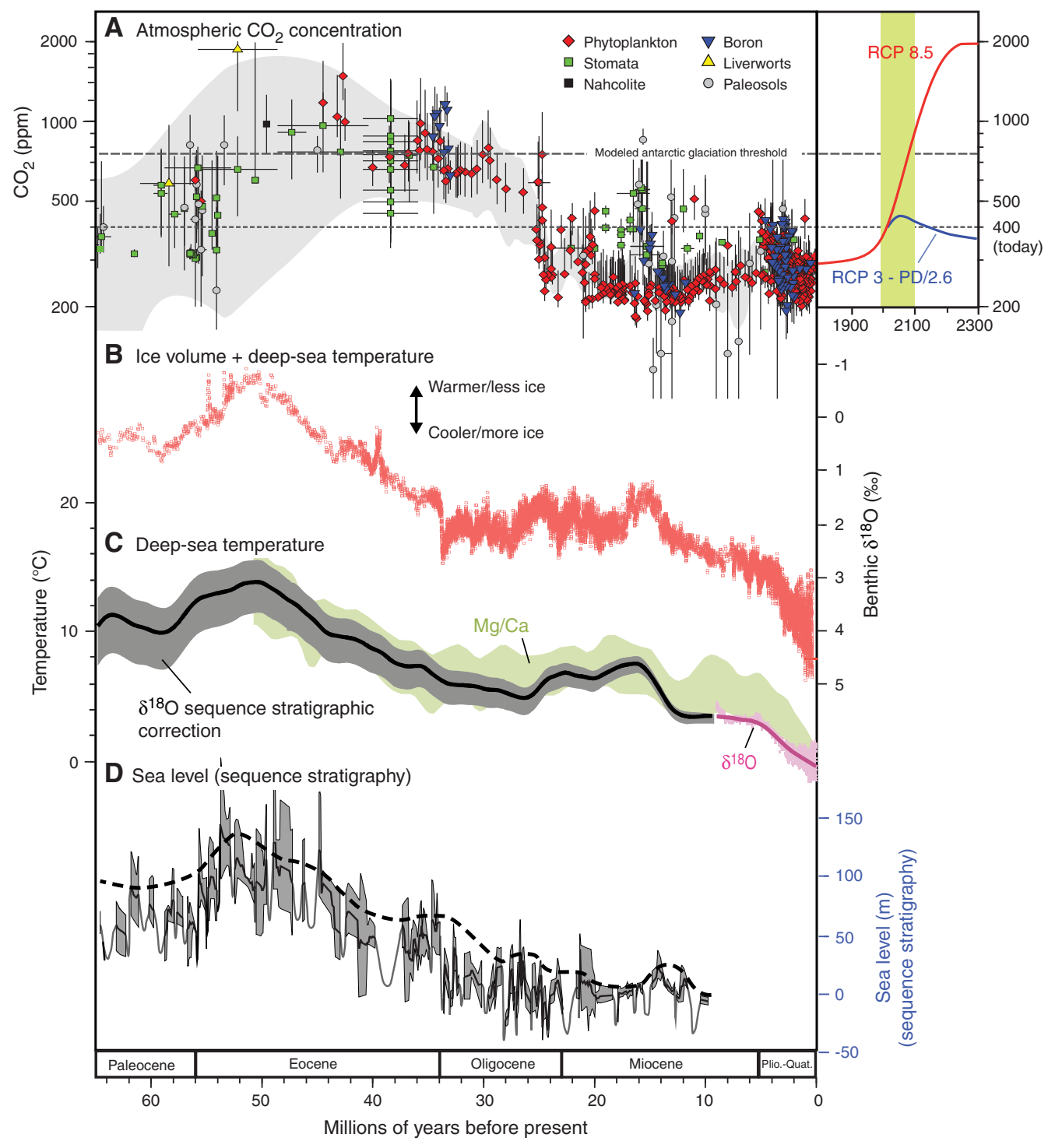

Unlike the Amundsen and Bellingshausen Seas, where the Antarctic Circumpolar Current (ACC) impinges the continental shelf and cross-shelf bathymetry encourages the presence of relatively warm Circumpolar Deep Water (CDW) on the inner shelf (Rignot and Jacobs, 2002), the eastern limb of the Ross Gyre brings cooler modified Circumpolar Deep Water (mCDW) to the Ross Sea along the lower continental slope (Whitworth et al., 1995; Orsi and Wiederwohl, 2009). The strong westward-flowing Antarctic Slope Current (ASC), which has a sharp subsurface front (Antarctic Slope Front), separates Antarctic Surface Water (AASW) on the shelf from $\mathrm{mCDW}$ on the lower continental slope (Figure F5). This front serves as a dynamic barrier that limits the transfer of CDW and
mCDW onto the Ross Sea continental shelf (Ainley and Jacobs, 1981). Thus, ASC vigor and the formation of fresh AASW regulate the volume of $\mathrm{mCDW}$ on the Ross Sea continental shelf.

\section{Geological setting and previous drilling}

The breakup of Gondwana during the Middle Jurassic began with the initiation of the West Antarctic Rift, which led to the opening of the Ross Sea (Behrendt et al., 1991) and the development of three sedimentary basins (Figures F2, F3) (Cooper et al., 1991). The westernmost Victoria Land Basin (VLB) was the focus of previous regional geological drilling (e.g., Dry Valley Drilling Project, McMurdo Sound Sediments and Tectonics Studies (MSSTS), Cenozoic 
Investigations in the Western Ross Sea [CIROS-1 and CIROS-2], Cape Roberts Project [CRP], and the Antarctic Geological Drilling Project [ANDRILL]). Expedition 374 focused on the Eastern Basin, which encompasses the Glomar Challenger Basin and contains as much as $6 \mathrm{~km}$ of Cenozoic sediment infill (Figure F3).

The basement geology of the Ross Sea Central High adjacent to the Eastern Basin was penetrated at Deep Sea Drilling Project (DSDP) Site 270 and consists of high-grade Paleozoic calcareous metamorphic rocks (Ford and Barrett, 1975) that were mylonitized during Late Cretaceous uplift (Siddoway et al., 2004). Upper Cretaceous mylonites were also recovered from the western part of the Eastern Basin (Luyendyk et al., 2001). The lack of basement younger than Devonian at CRP-3 and Site 270 suggests that younger Permian-Triassic Beacon Supergroup strata are likely absent in the Ross Sea. This interpretation is supported by paleogeographic maps from Barrett (1981) that, although poorly constrained, suggest that the Ross Sea was likely an area of uplift and erosion through much

Figure F2. Bathymetric map with Expedition 374 sites and previous DSDP Leg 28, AND, and CRP sites. Ross Sea bathymetry is from the International Bathymetric Chart of the Southern Ocean (Arndt et al., 2013a, 2013b). Existing seismic network is from the Antarctic Seismic Data Library System and includes some single-channel seismic-reflection profiles.

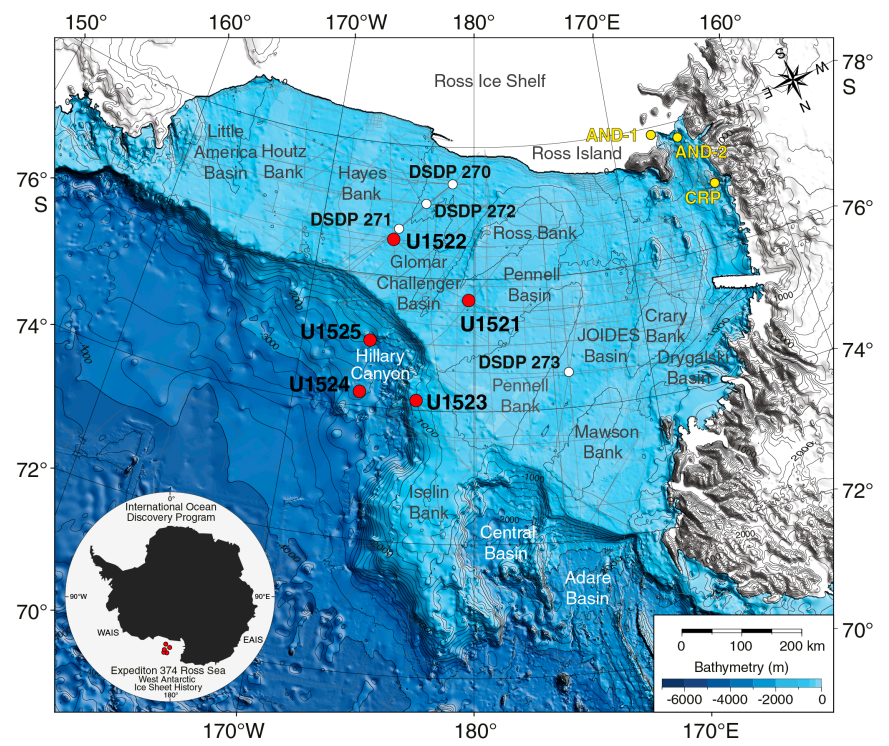

of the Permian-Triassic. The lower part of the Beacon Supergroup (Devonian) is dominated by coarse clastics (Barrett, 1981). The tectonic models for the formation of the Ross Sea, through the thinning of thickened $(\sim 40 \mathrm{~km})$ crust that extends across the entire Transantarctic Mountain (TAM)-Ross Sea-Marie Byrd Land region (Karner et al., 2005; Decesari et al., 2007), would also tend to argue against the preservation of upper Beacon Supergroup strata because uplift and erosion of these strata is predicted during early rifting. Consequently, rifting would result in a very different provenance signature for glacial deposits transported from the western compared with the eastern Ross Sea.

The Antarctic Offshore Stratigraphy (ANTOSTRAT) seismic stratigraphic scheme defines eight seismic units (RSS-1 to RSS-8) in the sediment infill above the basement. These seismic units are bounded by six major shelf-wide seismic unconformities (RSU1RSU6) (Figures F3, F6; Table T1) (Brancolini et al., 1995; De Santis et al., 1995) whose ages are only partially constrained by drilling (see synthesis by Bart and De Santis, 2012). In the western Ross Sea, CIROS-1 and CRP-3 indicate marine-terminating glaciation in the TAM by the earliest Oligocene (Barrett, 1989, 2007). Seismic-based reconstructions suggest ice caps nucleated on subaerially exposed basement highs in the central Ross Sea during the Oligocene. The adjacent deep-water basins in the outer Ross Sea appear to have remained free of grounded ice until the late Oligocene, although they were probably influenced by voluminous sediment-laden meltwater plumes associated with more temperate glacial sedimentation, resulting in progressive shoaling of the Eastern Basin as accommodation space filled (Shipboard Scientific Party, 1975a; De Santis et al., 1995). A major goal of Expedition 374 is to constrain the ages of RSU4 through RSU1 to understand how these features relate to the marine-based WAIS evolution.

Strata (Unit RSS-1) underlying RSU6 are the oldest and deepest basin-infill sedimentary packages in the central Ross Sea. Unit RSS1 is divided into lower and upper packages. The lower part of Unit RSS-1 has not been drilled, whereas the upper part was drilled in the western Ross Sea (CRP and CIROS-1) and consists of upper Eocene to Oligocene high-energy fluvial, deltaic, and shallow-shelf rift-fill strata, the uppermost of which were glacially influenced (Fielding et al., 2000; Galeotti et al., 2016). The lithology and age of the lowermost strata below RSU6 are uncertain because this interval has not been sampled, but it likely consists of coarse-grained fluvial facies deposited in the initial phases of Late Cretaceous to

Figure F3. Ross Sea seismic stratigraphy and previous drilling (see Figure F7 for transect line). Expedition 374 sites form a continental shelf-to-rise transect designed to tie into inner shelf sites and trace the Neogene and Quaternary evolution of the WAIS and the forcings and feedbacks influencing past variability.

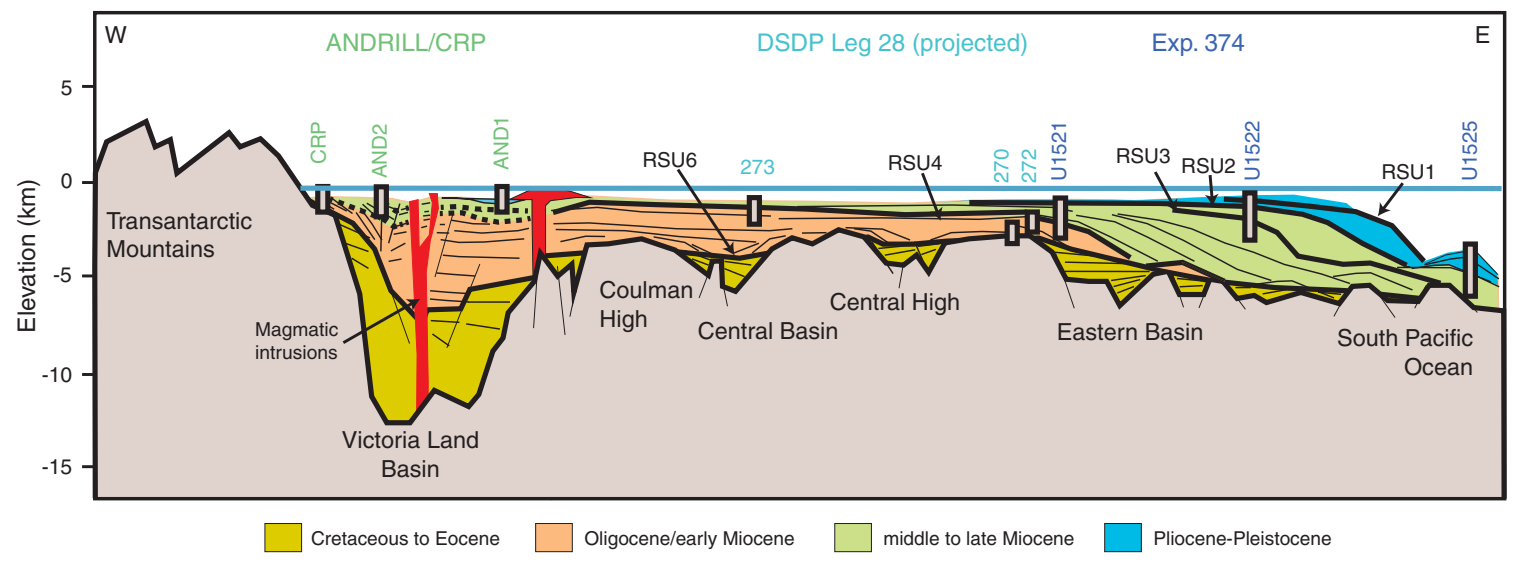


Figure F4. Expedition 374 sites are located in the most sensitive sector of the Antarctic for assessing ice sheet responses to (A) sea level and (B) ocean heat flux. LGM = Last Glacial Maximum. C-F. A more terrestrial West Antarctica in the Oligocene could support a larger ice sheet than present despite a warmer climate (Wilson et al., 2013). Thus, the timing of Ross Sea overdeepening has important implications for sea level budgets and for understanding mass balance controls. E-O = Eocene-Oligocene, Elev = elevation. G. The integration of sedimentological data with modeling was key to the success of ANDRILL (blue circle). Despite discontinuous sedimentation, targeting time intervals with short-duration magnetic reversals enabled orbital-scale WAIS reconstructions. Models indicate that grounded ice sheets occur at Sites U1521 and U1522 (black circle) during periods of maximum Antarctic ice volume. These ice-proximal sites will enable the assessment of the Antarctic contributions to sea level lowstands, building significantly on the ANDRILL record. Not all modeled glacial maxima are characterized by advance of ice to the continental shelf edge. ATNTS = astronomically tuned Neogene timescale.
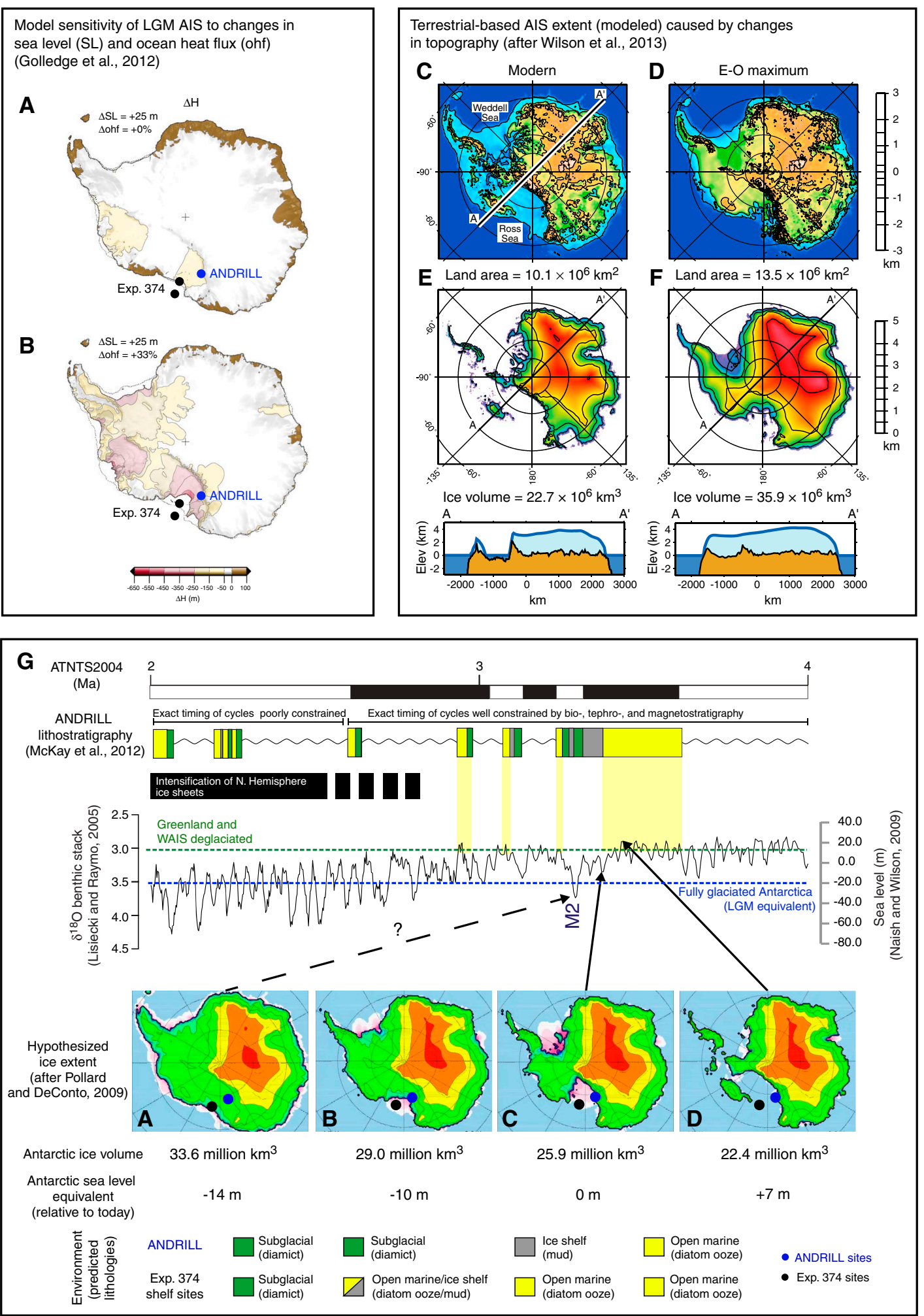
Figure F5. Ross Sea bathymetric map (from the International Bathymetric Chart of the Southern Ocean; Arndt et al., 2013a, 2013b). RSBW (blue arrow) derived from the ice shelf water (not shown) flows downslope in the Hillary Canyon and along the central and western Ross Sea shelf slope, contributing to deep waters (e.g., Antarctic Deep Water vs. Antarctic Bottom Water). The ASC carries surface waters westward along the continental shelf break. This along-slope flow also acts to regulate $\mathrm{mCDW}$ transport onto the continental shelf.

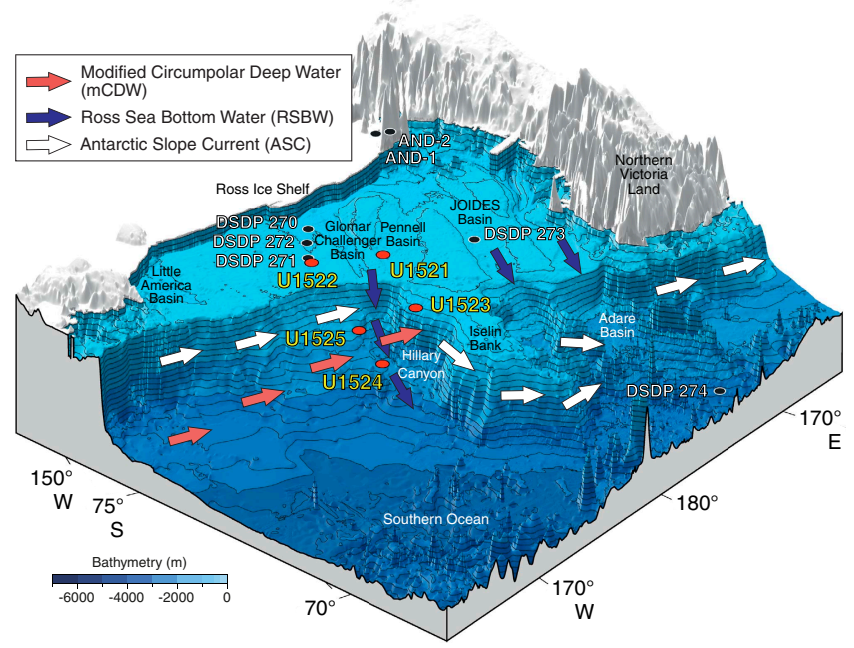

Paleocene rifting in the central Ross Sea (Wilson and Luyendyk, 2009).

The units overlying RSU6 have all been partially sampled by drilling, making the stratigraphic architecture in the Ross Sea relatively well constrained for this time period. However, most drill holes are located in isolated basins in the VLB of the western Ross Sea (Figures F2, F6), and thus basin-to-basin correlation remains uncertain. Direct correlation of RSU6 from across the various Ross Sea basins is not possible because the unconformity onlaps basement flanks (Figure F3). However, an inferred correlation can be made based on the distinctive acoustic character of the unconformity, which is a high-amplitude continuous reflector that is very distinct from the underlying seismic facies.

Upper Oligocene ( 28 Ma) to lower Miocene ( $20 \mathrm{Ma})$ strata at Site 270 consist of a $365 \mathrm{~m}$ thick sequence of lithified glaciomarine mudstone with ice-rafted debris (IRD) and common macro- and microfossils (Hayes et al., 1975; Leckie and Webb, 1986), suggesting a shallow continental shelf environment with mudstone facies indicative of times with abundant terrestrial runoff. Shallower than 100 meters below seafloor (mbsf), many of the units (originally classified as mudstone) are lower Miocene diamictite (i.e., $>25 \%$ sand, according to the classification scheme used in this volume) that were eroded and transported by glacial ice (Barrett, 1975).

Figure F6. Chronostratigraphic summary of Ross Sea drilling. Seismic stratigraphy is constrained by drilling in Victoria Land Basin (SR-VLB) but not in the Central and Eastern Basins (EB-RSU). Postcruise research from the Expedition 374 sites will reduce uncertainties associated with RSU2-RSU4 and assess the spatial coherency of these erosional features. Far-field climate $\left(\delta^{18} \mathrm{O}\right), \mathrm{CO}_{2}$, carbon cycle $\left(\delta^{13} \mathrm{C}\right)$, Equatorial Pacific carbonate compensation depth $(C C D)$, and sea level records discussed in the text are indicated. TD $=$ total depth, NJM $=$ New Jersey margin.

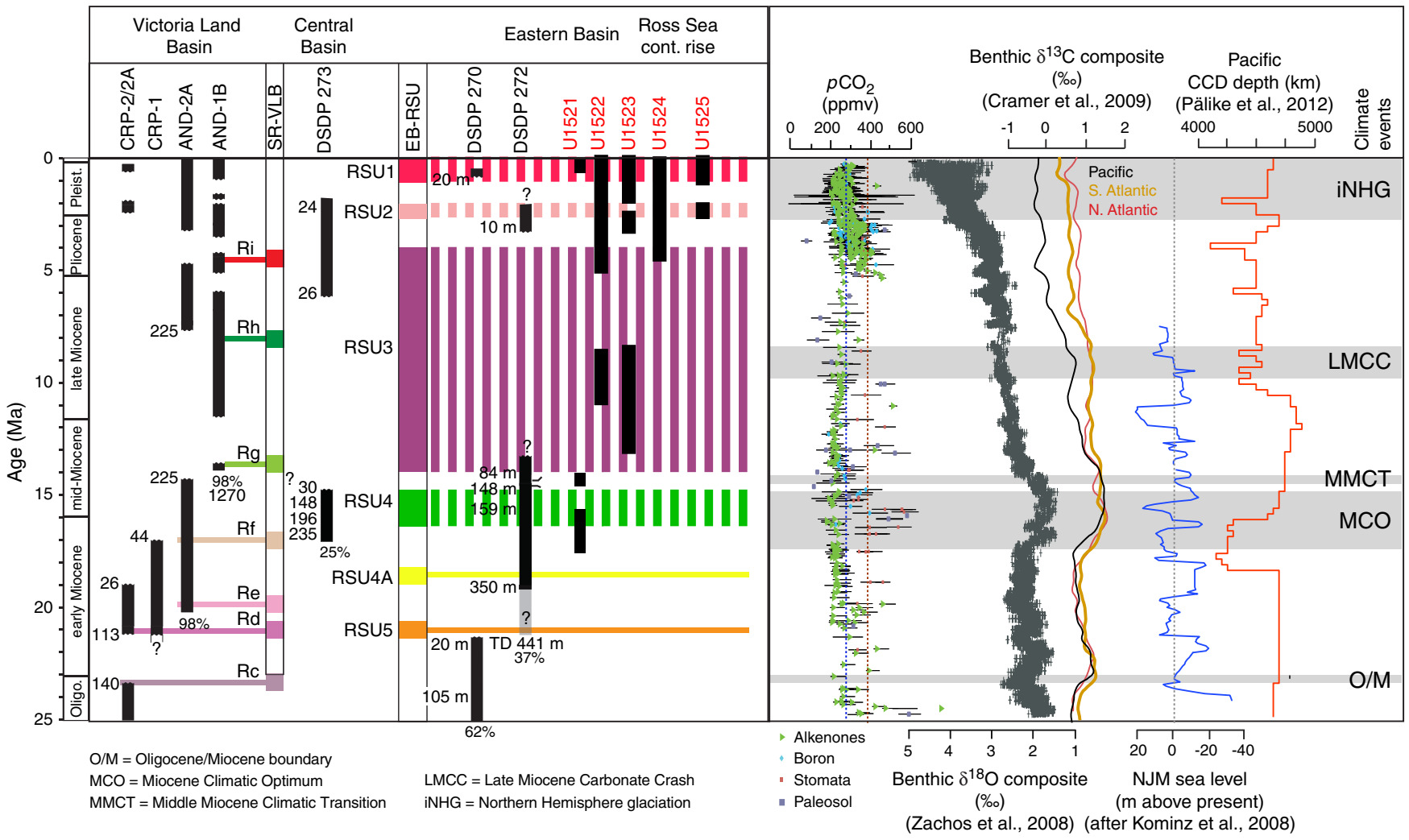


Table T1. Summary of Ross Sea stratigraphy prior to Expedition 374 drilling. Based on Brancolini et al. (1995) Antarctic Offshore Stratigraphy (ANTOSTRAT) project. Expedition 374 will provide new constraints for the ages of some of the main unconformities and seismic sequences. RSS $=$ Ross Sea sequence, RSU $=$ Ross Sea unconformity. Download table in CSV format.

\begin{tabular}{|c|c|c|c|}
\hline Sequence & Sequence seismic character & Age & $\begin{array}{c}\text { Bottom } \\
\text { unconformity }\end{array}$ \\
\hline RSS-8 & Aggradational topset beds underlying locally backstepping grounding zone wedge & Pleistocene & RSU1 (0.7 Ma?) \\
\hline RSS-7 & Aggradational topset beds & Pliocene & RSU2 (4 Ma?) \\
\hline RSS-6 & Shelf topset beds and prograding trough mouth fan at the shelf edge & late Miocene & RSU3 (12 Ma?) \\
\hline RSS-5 & Alternating subsequences of grounding zone prograding wedges and subhorizontal strata packages & mid-Miocene & RSU4 (14-16 Ma?) \\
\hline RSS-4 & Grounding zone prograding wedges and subhorizontal strata packages & early Miocene & RSU4a (18.5 Ma?) \\
\hline RSS-3 & Alternating subsequences of grounding zone prograding wedges and subhorizontal strata packages & early Miocene & RSU5 (21 Ma?) \\
\hline RSS-2 & Alternating subsequences of grounding zone prograding wedges and subhorizontal strata packages & late Oligocene-early Miocene & RSU6 (29 Ma?) \\
\hline RSS-1 (upper) & Subhorizontal strata filling basement basins & late Eocene-early Oligocene & RSU7 \\
\hline RSS-1 (lower) & Subhorizontal strata filling basement basins & ?Late Cretaceous & Basement \\
\hline
\end{tabular}

Two ANDRILL sites drilled on the inner continental shelf of the western Ross Sea (98\% recovery) contain unprecedented records of marine-based ice sheet variability (Naish et al., 2009; Fielding et al., 2011; Wilson et al., 2012; Patterson and Ishman, 2012; Levy et al., 2016) over the past $20 \mathrm{My}$, although both sites are influenced by the East Antarctic Ice Sheet (EAIS). Drilling at Antarctic Geological Drilling Project (AND) Site AND-2A recovered a $\sim 20-14$ Ma sequence interpreted to reflect TAM outlet glaciers overriding and/or calving near the site (Fielding et al., 2011; Passchier et al., 2011; Levy et al., 2016). A diatomite (dated to $15.7 \mathrm{Ma}$ ) with abundant dinoflagellate cysts (dinocysts), foraminifers, pollen, and other biomarkers suggests a warmer-than-present $\left(\sim 11^{\circ} \mathrm{C}\right.$ mean surface temperature) and hydrologically active climate during the MCO (Warny et al., 2009; Feakins et al., 2012).

At 300 mbsf in Core AND-2A, a 300 ky disconformity equivalent to RSU4 (middle Miocene) suggests a shelf-wide advance of grounded marine-based ice originating from the EAIS during the MMCT (Figures F6, F7, F8) (De Santis et al., 1999; Passchier et al., 2011; Levy et al., 2016). This unconformity is the first unequivocal seismic evidence for a glacially carved trough in the central Ross Sea and is a key target of Site U1521 (Figures F7, F8) (De Santis et al., 1995; Ten Brink et al., 1995; Anderson, 1999; Anderson et al., 2018; Colleoni et al., 2018a). At DSDP Site 272, a 400 m thick early-middle Miocene sequence of glaciomarine mudstone was recovered (Shipboard Scientific Party, 1975b) (Figure F6). Approximately 250 $\mathrm{m}$ of till foreset and aggrading bottomset strata above RSU4 (De Santis et al., 1997) is associated with numerous outwash channels, suggesting the region was influenced by large volumes of erosive sediment-laden meltwater during the middle Miocene ( $14 \mathrm{Ma}$; Figure F8) (Anderson and Bartek, 1992; Chow and Bart, 2003) that may have been associated with extensive channel-levee systems above RSU4 on the continental slope and rise (De Santis et al., 1995, 1999).

Post-MCO cooling and glaciation caused multiple erosional episodes across the shallow central Ross Sea, which resulted in poor preservation of the Site 272-recovered foreset strata that thicken toward the Central High within a thick, gently seaward-dipping section, suggesting that middle Miocene glaciation records may be preserved in the eastern Ross Sea (De Santis et al., 1997; cf. Figures F7, F8). Evidence for glacial erosion and deposition in the southeasternmost Ross Sea in the Oligocene suggests the presence of an ice cap on Marie Byrd Land (Sorlien et al., 2007). However, in the mid- to late Miocene, the eastern Ross Sea was still a wide, gently sloping seaward embayment surrounded by grounded ice that was deliver- ing sediments to the slope from the Central High and Marie Byrd Land.

RSU3, a key target of Site U1522, provides the first evidence for a major cross-shelf paleotrough eroded by an expanded WAIS, although the age of this event(s) is poorly constrained ( 14-4 Ma; Figures F6, F7) (De Santis et al., 1995, 1999; Bart, 2003). Large meltwater and outwash features are absent, and laminated seismic facies are progressively thinner/less common in strata younger than RSU3, suggesting sediment starvation and a transition to a colder glacial regime. The inner-continental shelf Site AND-1B sediments indicate that this transition may not have occurred until the Pliocene (McKay et al., 2009), although evidence for meltwater outburst features is lacking in the TAM after 12.4 Ma (Lewis et al., 2006).

High-velocity seismic units above RSU3 and RSU2 suggest overcompaction by ice-loading during WAIS expansion (Böhm et al., 2009). Bathymetric reconstructions suggest that overdeepening, with a transition to a landward-deepening continental shelf, occurred by the RSU2 event during the early Pliocene to early Pleistocene(?) (Figure F7) (De Santis et al., 1995, 1999). A trough-mouth fan on the upper slope and a sediment-starved continental rise (typical of the Plio-Pleistocene Antarctic margin) coincided with overdeepening (Bart et al., 1999; Cooper and O'Brien, 2004; Rebesco et al., 2006; Bart and Iwai, 2012).

At Site AND-1B, $~ 58$ sedimentary cycles of ice sheet advance and retreat are observed in the Ross Embayment over the past 13 My (McKay et al., 2009). Diatomites indicate frequent collapses of the WAIS in the Pliocene (5.3-2.6 Ma), during which diatom assemblages and geochemical paleothermometry indicate ocean temperatures were as much as $4^{\circ} \mathrm{C}$ warmer than present (Naish et al., 2009; McKay et al., 2012a). However, sedimentary lithofacies are dominated by pelagic diatom ooze, indicating that meltwater discharge was reduced during Pliocene interglacials compared with thick glaciomarine mudstone deposited during the late Miocene (11-5.3 $\mathrm{Ma})$. By the mid-Pleistocene (1.0 Ma), the Ross Ice Shelf persisted through most interglacials (McKay et al., 2009).

Seismic facies above RSU2 are indicative of till sheets bound by erosional unconformities in an aggrading shelf margin caused by shelf-wide advances of the WAIS (Figure F7) (Alonso et al., 1992; Brancolini et al., 1995; Bart et al., 2011). Unlike other sectors of the Antarctic, the eastern Ross Sea trough mouth contains thick ( 2000 $\mathrm{m})$ sedimentary sequences on the shelf and upper continental slope that may contain a detailed WAIS history. Above RSU1 (0.7? Ma), shelf-edge sediments are aggrading or backstepping (rather than prograding; Bart et al., 2018), indicating that most sediment deliv- 
Figure F7. A-D. TWT depth maps for selected regional seismic ANTOSTRAT unconformities with interpretations of ice sheet history (after Brancolini et al., 1995) and location of Expedition 374 sites. Maps of RSU4, RSU3, and RSU2 have now been extended into the continental slope and rise area (E. Olivo, unpubl. data; not shown) and into the western Ross Sea as part of the IPY Rossmap project. Gray shading in A shows the areas lying above sea level at the time of RSU6 on the basis of DSDP Site 270 stratigraphy. Site U1521 is located at the ocean margin of one of these areas, which subsided in the early Miocene and was cut by a large glacial valley by the early to mid-Miocene. Site U1521 will provide environmental information about paleo-ice stream and ocean current interplay during the middle Miocene. Site U1522 is located at the edge of a large embayment of the continental shelf in the eastern Ross Sea, where WAIS streams have carved glacial valleys since RSU3. Sites U1521-U1525 will provide subglacial ice-proximal (Site U1522), glaciomarine ice-proximal (Site U1523) to ice-distal (Sites U1525 and U1524) Miocene to Pleistocene records of past ice sheet/ocean interactions.

A

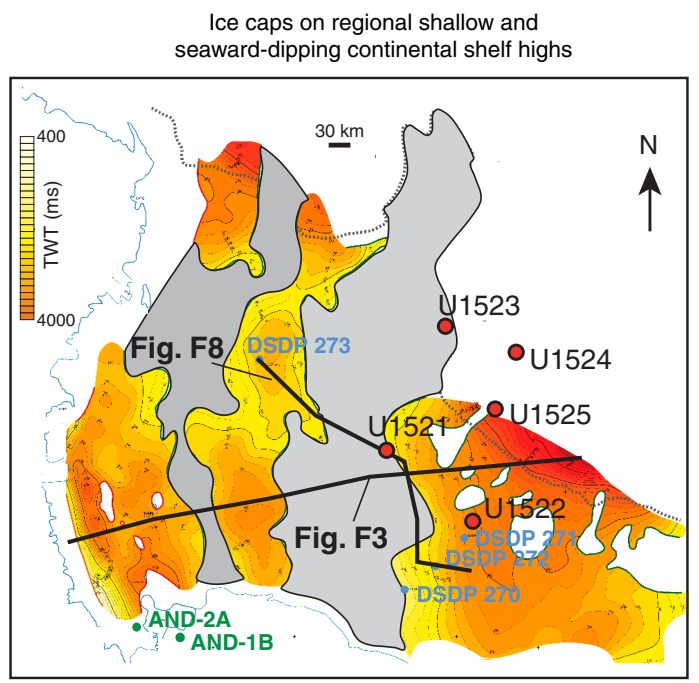

C
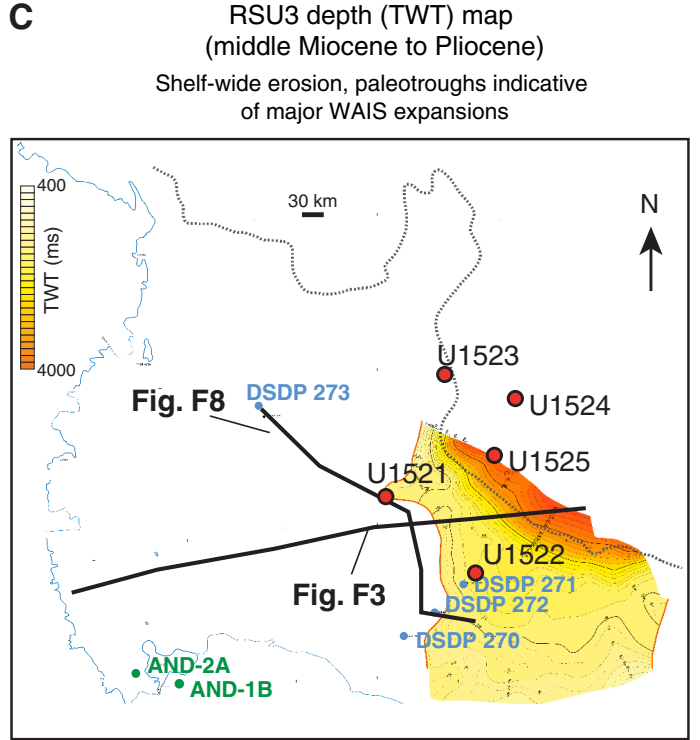

ered from land was sequestered on the outer shelf or bypassed the continental shelf to be transported directly into the deep sea.

\section{Site survey data}

Multichannel seismic (MCS) and single-channel seismic (SCS) profiles have been collected in the Ross Sea by several nations since 1980. MCS data are available through the Antarctic Seismic Data Library System, which works under the auspices of the Scientific Committee on Antarctic Research and the Antarctic Treaty (ATCM XVI-12). Prestack data are available only from the Italian cruises (1988, 1989, 1991, 1994, and 2006) and recently also from the BGR80 cruise.

\section{B $\quad$ RSU4 depth (TWT) map (middle Miocene)}

First evidence of ice-stream trough (from EAIS?) shallow seaward-dipping continental shelf

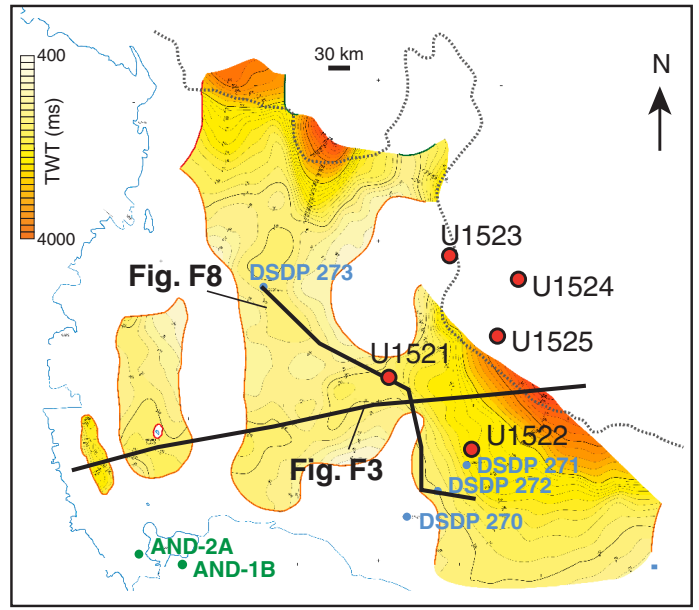

D

RSU2 depth (TWT) map

(late Pliocene to early Pleistocene)

Development of reversed slope and overdeepening of continental shelf overlain by tills deposited by marine ice sheets

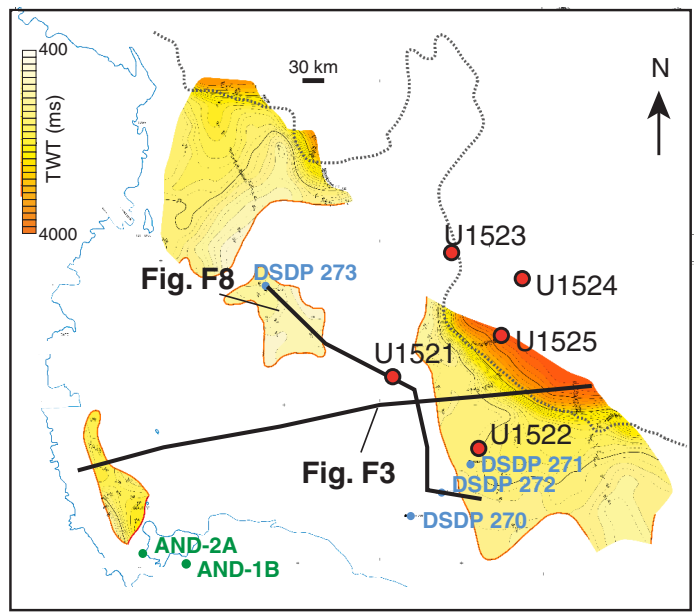

We selected sites based on maximum thickness of target sequence, potential for dating sediments, and acoustic facies and geometry of deposits, which usually can be seen more clearly on highresolution profiles. In most cases, high-resolution profiles are single channel, or in the case of the TAN060_08 profile, they have a very short streamer $(200 \mathrm{~m})$ relative to the water depth $(>1000 \mathrm{~m})$. In some cases, crossing lines are not available; the remoteness of Antarctic water and the presence of sea ice prevents the easy collection of new site survey data. New MCS Profiles KSL14-02 and KSL14-04 (Kim et al., 2018) were collected in February 2013 and in 2015 by the Korea Polar Research Institute (KOPRI) with the aim of providing cross-lines for several proposed sites. Another SCS survey cruise 
Figure F8. Composite seismic cross section of Lines PD90-34, PD90-35, and PD90-36 (after Anderson and Bartek, 1992; De Santis et al., 1995) showing a transect across the central Ross Sea that includes DSDP Sites 272 and 273 and Site U1521. The seismic-reflection profile and age constraint from the sites document that this area was filled with glacial sediments ( $250 \mathrm{~ms}$ TWT thick) during the early Miocene, suggesting ice advance from the south or southwest. Green reflector = interpreted RSU4 carving a large southeast-northwest-oriented trough across the central Ross Sea (see Figure F7 for transect line). Site U1521 records sediment below and above RSU4, providing information of ice-volume growth and retreat during the early Miocene cooling, the middle Miocene, and the Middle Miocene Climatic Transition. Seismic lines are single-channel seismic-reflection profiles (air gun 2.6 I) collected by Rice University, TX (USA), in 1990 (Anderson and Bartek, 1992). SP = shotpoint.

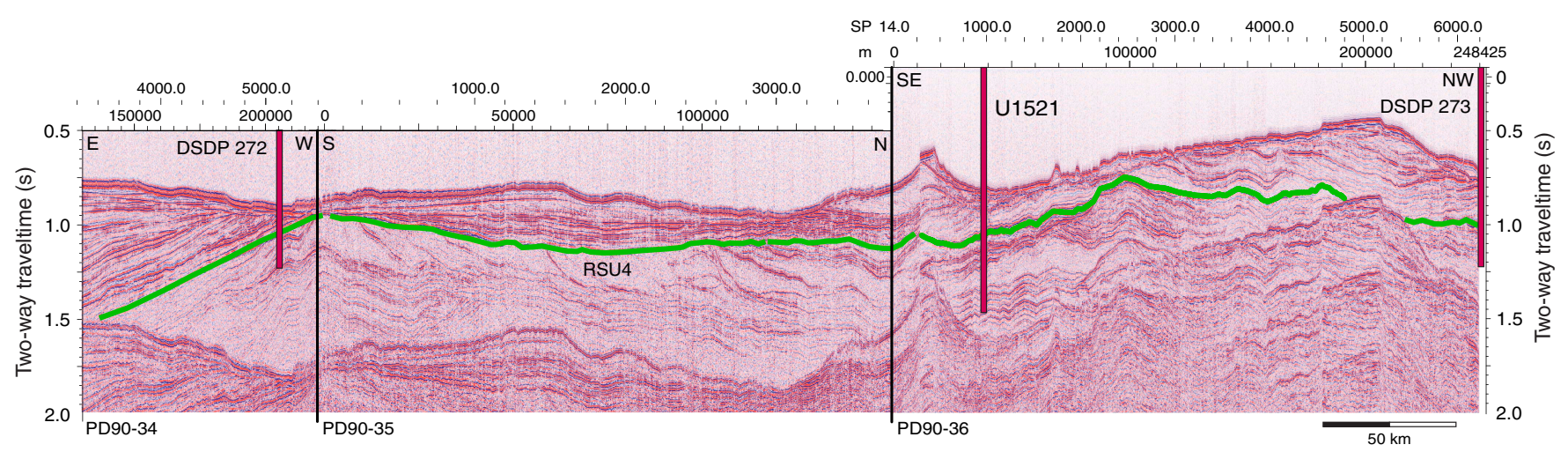

was conducted in 2017 (EU/FP7 EUROFLEETS2 ANTSSS project and Programma Nazionale di Ricerche in Antartide WHISPERS and ODYSSEA projects) with the aim to collect additional crosslines for proposed sites and to identify alternate sites.

SCS data, collected by National Science Foundation (NSF) Cruises in 1990 and 1994-1995 were made available by John Anderson (Rice University, TX) as digital SEGY data (Cruise PD90) and paper copies (Cruise NBP 94-95). We made the conversion of the TIFF or JPG image to SEGY format to depth-convert the sections and load the data in the IHS Kingdom interpretation software with the other available data sets. The supporting site survey data for Expedition 374 are archived in the IODP Site Survey Data Bank (https://ssdb.iodp.org/SSDBquery/SSDBquery.php; select proposal number P751).

\section{Scientific objectives}

\section{Evaluate the contribution of West Antarctica to far-field ice vol- ume and sea level estimates.}

Far-field benthic foraminifer $\delta^{18} \mathrm{O}$ and sequence stratigraphic records suggest that large global ice volume and sea level $(20-60 \mathrm{~m})$ variations occurred during the Miocene and Pliocene (Figures F1, F6) (Zachos et al., 2001; Miller et al., 2005, 2012; Cramer et al., 2009; Raymo et al., 2011). Miocene-Pliocene sea level reconstructions could potentially be reconciled without invoking large Northern Hemisphere contributions if Antarctica's ice sheets expanded to the continental shelf edge ( $14 \mathrm{~m}$ sea level equivalent [SLE]) (Figure F4). The modeled difference between the glacial maxima states and loss of the marine-based WAIS (assuming present bathymetry) represents $\sim 21 \mathrm{~m}$ SLE (with some minor loss of the EAIS), although changes in Ross Sea bathymetry could increase this value (Colleoni et al., 2018a) (Figure F4) (see Objective 5). Expedition 374 records will help constrain the timing of the first WAIS advances to the shelf edge, and integration with ANDRILL records will allow assessment of the WAIS contribution to Neogene sea level estimates.

Sedimentological and micropaleontological analyses at continental shelf Sites U1521 and U1522, combined with seismic stratigraphic correlations, will identify deposition under grounded-ice, glaciomarine, and open-marine conditions following $\mathrm{AN}$ -
DRILL/CRP methodology (Fielding et al., 2000, 2011; Powell and Cooper, 2002; McKay et al., 2009; Passchier et al., 2011). Magneto-, bio-, and tephrochronology will enable identification of orbitalscale ice sheet variations and have been employed in discontinuous Antarctic margin sequences (Florindo et al., 2003, 2005; Tauxe et al., 2012; Wilson et al., 2012) (Figure F4). Furthermore, new quantitative techniques have greatly enhanced the biostratigraphic framework of the Southern Ocean (Cody et al., 2008, 2012; Crampton et al., 2016). Glacially reworked volcanic clasts (Wilson et al., 2012) and radiometrically datable felsic ashes from Marie Byrd Land may be used to provide maximum ages (Wilch et al., 1999). Climate snapshots near magnetic reversals will be targeted (e.g., the M2 glacial in Figure F4) because these events can be traced to more continuous records from the continental rise (Site U1524) and global sea level records. Sediment provenance studies (clast/sand petrology, mineral thermochronology, and radiogenic isotope analysis) at Sites U1521 and U1522 will enable understanding of the changes in the origin of sediments (e.g., local ice caps versus ice sheet expansion and provenance from East versus West Antarctic sources) (Figure F7) (Licht et al., 2005, 2014; Talarico et al., 2012; Cook et al., 2013; Perotti et al., 2017; Simões Pereira et al., 2018). As with all objectives, data integration with modeling studies will be undertaken (Figure F4) (Golledge et al., 2012; Wilson et al., 2013; DeConto and Pollard, 2016; Gasson et al., 2016; Colleoni et al., 2018b).

2. Reconstruct ice-proximal atmospheric and oceanic temperatures to identify past polar amplification and assess its forcings/feedbacks.

Obtaining atmospheric and ocean temperatures from the Expedition 374 drill sites will enable the paleoclimate community to address the following key scientific questions:

- Were polar temperatures sensitive to the low-amplitude variations in Neogene atmospheric $p \mathrm{CO}_{2}$ ?

- Were Neogene ocean and atmospheric temperatures at the Antarctic margin amplified relative to the global mean, and if so, what were the forcings?

- How did ocean temperatures evolve as Antarctica's ice sheets expanded and contracted during major Neogene climate transitions and on orbital timescales? 
Although the ANDRILL records provide important archives of high-latitude oceanic conditions, they only provide snapshots of temperature and sea ice conditions through interglacials, when these sites were not covered by ice (Warny et al., 2009; McKay et al., 2012a; Levy et al., 2016). In contrast, Sites U1521 and U1522 provide intervals of more continuous sedimentation (albeit with some periods of erosion during large glaciations) because they are in paleobathymetric depressions that provided the accommodation space needed for preservation after ice expansion (De Santis et al., 1995). These sites are also farther out on the continental shelf, near the paleoshelf break (Figure F7), and are therefore less likely to be frequently overridden by grounded ice (Pollard and DeConto, 2009; Bart et al., 2011). More continuous records of oceanographic change were recovered at Sites U1523-U1525, providing high-latitude information on late Neogene and Quaternary ocean and atmospheric temperatures, meltwater input, and bottom water production.

Lithofacies analysis will be used to reconstruct glacial thermal regimes and glacial cyclicity (cf. McKay et al., 2009; Naish et al., 2009), whereas diatom and radiolarian census counts, marine and terrestrial palynology, organic biomarkers (e.g., $\mathrm{TEX}_{86}$, branched and isoprenoid tetraether [BIT] index, and methylation of branched tetraether $[\mathrm{MBT}] /$ cyclization of branched tetraether [CBT] proxy; cf. McKay et al., 2012a; Levy et al., 2016; Sangiorgi et al., 2018), and redox-sensitive metals (e.g., $\mathrm{Mn}, \mathrm{U}, \mathrm{Re}$, and Mo) provide records for paleoproductivity, high-latitude marine and terrestrial climate, and oceanography. Lithofacies analysis is also relevant to monitoring alteration of the biomarkers by methanogenesis and shifting redox boundaries. Biogenic carbonate (e.g., calcareous nannofossils/foraminifers) is also present in Expedition 374 Neogene and upper Pleistocene interglacial sequences and at other circum-Antarctic sites (e.g., Theissen et al., 2003; Scherer et al., 2008; Villa et al., 2008; Expedition 318 Scientists, 2011). In the lower to middle Miocene, biogenic carbonate is more common in the Southern Ocean and Antarctic margins (Hayes et al., 1975; Kennett and Barker, 1990; Shipboard Scientific Party, 2001; Shevenell et al., 2004; Expedition 318 Scientists, 2011; Fielding et al., 2011), making stable isotope $\left(\delta^{18} \mathrm{O}\right.$ and $\delta^{13} \mathrm{C}$ ), trace element (e.g., $\mathrm{Mg} / \mathrm{Ca}, \mathrm{Li} / \mathrm{Ca}, \mathrm{U} / \mathrm{Ca}, \mathrm{Ba} / \mathrm{Ca}$, and $\mathrm{B} / \mathrm{Ca}$ ), and clumped isotope analyses possible. However, for all of the proxies discussed above, their strengths/weaknesses in a marginal marine setting should be considered.

\section{Assess the role of oceanic forcing (e.g., sea level and temperature) on WAIS stability/instability.}

WAIS retreat events during past warmer-than-present climates may have been the consequence of intensified ocean-cryosphere interactions (Naish et al., 2009; Pollard and DeConto, 2009). Interactions between the wind-driven upwelling of warm CDW and the ice shelves that buttress the WAIS appear to play a significant role in modern ice mass loss in West Antarctica (e.g., Mercer, 1978; Joughin et al., 2012; Pritchard et al., 2012; Shepherd et al., 2012). Observations and numerical ice sheet models suggest that changes in ocean heat flux are a key factor influencing the stability/instability of the WAIS (Golledge et al., 2012; Pritchard et al., 2012; DeConto and Pollard, 2016; Rintoul et al., 2018). We postulate that changes in either the formation of AASW and AABW or the vigor of the wind-driven ASC control incursions of CDW onto the Ross Sea continental slope and shelf and the resultant retreat of the WAIS (Figure F5). The records from Expedition 374 will allow us to test this hypothesis by simultaneously assessing AASW/AABW/ASC changes from grain size and lithofacies analysis of sediment mounds on the continental shelf bank, slope, and rise (e.g., Sites U1523U1525) and ice sheet extent in the Ross Embayment (Sites U1521 and U1522, DSDP Site 272, and ANDRILL sites).

The Ross Sea is also one of the three main sources of AABW that feed the abyssal ocean (to become Southern Component Water [SCW]). In the middle Miocene, benthic foraminifer $\delta^{13} \mathrm{C}$ indicates changes in the relative input of SCW and Northern Component Water (NCW) into the global ocean (Woodruff and Savin, 1985; Wright et al., 1991; Shevenell et al., 2004; Cramer et al., 2009). Newer proxies, such as $\mathrm{Nd}$ isotopes, are now used to further refine the geographic source of deep-water production (e.g., van de Flierdt et al., 2004; Scher and Martin, 2006; Newkirk and Martin, 2009; Huck et al., 2017). Thus, the records obtained during Expedition 374 and comparison with far-field records will provide insight into temporal changes in SCW production through the Neogene (Vincent and Berger, 1985; Flower and Kennett, 1994; Hodell and VenzCurtis, 2006).

Paleocurrent strength associated with past ASC changes and the history of AABW transport through the Hillary Canyon will be reconstructed by examining the sedimentological (e.g., lithofacies analysis and grain size) and magnetic characteristics of Sites U1523-U1525 (e.g., Bianchi et al., 1999; Hall et al., 2001; Prins et al., 2002; Joseph et al., 2004). Micropaleontological, geochemical, and sedimentological records from drill cores from all Expedition 374 sites will provide reconstructions of changing regional surface and seafloor conditions (e.g., sea ice, surface stratification, sea-surface temperatures [SSTs], polynya mixing, glacial meltwater discharge, nutrient uptake, and supercooling of dense water by ice shelves) proximal to the AISs (e.g., Shevenell et al., 2011; McKay et al., 2012a; Houben et al., 2013; Levy et al., 2016; Sangiorgi et al., 2018) and thus AABW (and SCW) formation. Additionally, downslope currents resulting from the transfer of High-Salinity Shelf Water into the abyssal ocean can also be assessed (and distinguished from ASC flow) by integrated lithofacies analysis, geochemistry, micropaleontology, and seismic-reflection profiles (e.g., Hepp et al., 2006; Lucchi and Rebesco, 2007; Caburlotto et al., 2010; Kim et al., 2018) at Sites U1523-U1525. Carbonate-based paleotemperature and carbonate ion proxies (e.g., foraminiferal $\mathrm{Mg} / \mathrm{Ca}, \mathrm{Li} / \mathrm{Ca}, \mathrm{U} / \mathrm{Ca}$, and clumped isotopes) will also be applied where appropriate species are preserved (see Objective 2).

\section{Identify the sensitivity of WAIS to Earth's orbital configuration under a variety of climate boundary conditions.}

Fundamental questions remain about the orbital pacing of AIS development and variability. The Ross Sea Expedition 374 sequences will shed light on the absence of the $20 \mathrm{ky}$ precession cycle in benthic $\delta^{18} \mathrm{O}$ records (Figure F4) (Lisiecki and Raymo, 2005; Huybers, 2006; Raymo et al., 2006) and the origin of transient shifts in the sensitivity of Earth's climate system to orbital forcing (e.g., 40$100 \mathrm{ky}$-dominated frequencies) in the middle Miocene (Shevenell et al., 2004) and Plio-Pleistocene (Tzedakis et al., 2017).

A recent hypothesis suggests that the last such shift in Earth history (the mid-Pleistocene transition) was initiated by an abrupt increase in Antarctic ice volume (Elderfield et al., 2012). This hypothesis may be tested by identifying and dating grounding events on the outer Ross Sea continental shelf. If the dominant frequency of AIS advance and retreat shifted from 40 to $100 \mathrm{ky}$ at 0.8 $\mathrm{Ma}$, records from this sensitive region will likely record this transition.

Recent evidence from ice-proximal drill sites indicates that AISs did advance and retreat with 40 and 100 ky cyclicity in the Neogene 
(Grützner et al., 2003; Williams and Handwerger, 2005; Naish et al., 2009; Patterson et al., 2014). We envision a more complete picture of the forcings and feedbacks involved with ice advance and retreat from our outer shelf to slope/rise transect. Sedimentological analyses (complemented by downhole logs) will enable development of an orbital-scale continental shelf-to-rise sequence stratigraphy of glacial advance and retreat (all Expedition 374 sites; see Objective 1). Additional micropaleontologic data, inorganic and organic geochemistry (e.g., $\delta^{18} \mathrm{O}, \delta^{13} \mathrm{C}, \mathrm{Mg} / \mathrm{Ca}$, and $\varepsilon_{\mathrm{Nd}}$ ), minor and trace elements (X-ray fluorescence and discrete samples), and organic biomarkers may be used to assess associated frequencies of change in the outermost continental shelf, slope, and rise sites (U1523U1525).

\section{Reconstruct eastern Ross Sea bathymetry to examine relation- ships between seafloor geometry, ice sheet stability/instability, and global climate.}

The transition from a terrestrial (or shallow marine) West Antarctica with a seaward-dipping shallow continental shelf to that of the modern overdeepened (i.e., landward dipping) continental shelf would have had a first-order control on AIS volume and mass balance (Wilson et al., 2013; Gasson et al., 2016). The cooling threshold for the development of a terrestrial-based ice sheet is lower than that of a marine-based ice sheet, which is highly sensitive to changes in oceanic heat flux (Figure F4) (Pollard and DeConto, 2009; Golledge et al., 2012; Colleoni et al., 2018a). A terrestrial (or shallow marine) West Antarctica may have supported a larger ice sheet in warmer-than-present climates, whereas overdeepening of the continental shelves may have resulted in a smaller ice sheet with less frequent ice sheet advances, as hypothesized for the Antarctic Peninsula (e.g., Bart and Iwai, 2012). Ice sheet models indicate that a largely terrestrial West Antarctica could accommodate an extra $\sim 13$ million $\mathrm{km}^{3}$ of grounded ice in the warmer-than-present climate of the Eocene ( 30 m SLE; Figure F4) (Wilson et al., 2013). Therefore, constraining the timing of overdeepening in the Ross Sea is critical to reconcile far-field records of eustatic sea level variance into the late Neogene and Quaternary (see Objective 1).

The timing of Ross Sea shelf overdeepening is currently unconstrained. However, the Ross Sea has the most developed seismic framework in Antarctica and the highest resolution history of WAIS variability currently available (ANDRILL), making this location ideal for achieving this objective. Dating the sedimentary sequence and providing information about the depositional environment at the time of formation of RSU3 and RSU2 (Figure F6) at Sites U1521 and U1522 in the eastern Ross Sea (by methodologies in Objective 1) will constrain the timing of this overdeepening (Figure F7).

\section{Site summaries}

\section{Site U1521}

\section{Background and objectives}

Site U1521 (proposed Site EBOCS-01D) is located in the Pennell Basin at $75^{\circ} 41.0351^{\prime} \mathrm{S}, 179^{\circ} 40.3108^{\prime} \mathrm{W}$ at $562 \mathrm{~m}$ water depth (Figure F9). The site is on the continental shelf near a northeast-southwestoriented Miocene paleotrough identified by mapping regional unconformities in seismic-reflection profiles. The primary objective at Site U1521 was to sample and date strata above and below RSU4, which was previously identified in seismic stratigraphic studies (Hinz and Block, 1984; Anderson and Bartek, 1992; Cooper et al., 1997) (Figure F10). RSU4 is a regional angular unconformity (Figure F8) that has been mapped over most of the Ross Sea and is in-
Figure F9. Bathymetric map with locations of Site U1521, other Expedition 374 sites, DSDP Leg 28 Sites 270-273, and ANDRILL Cores AND-1 and AND-2. Red box = location of inset map with Site U1521 on seismic-profile Line PD90-36 (Figure F10). Bathymetry from Arndt et al., 2013.

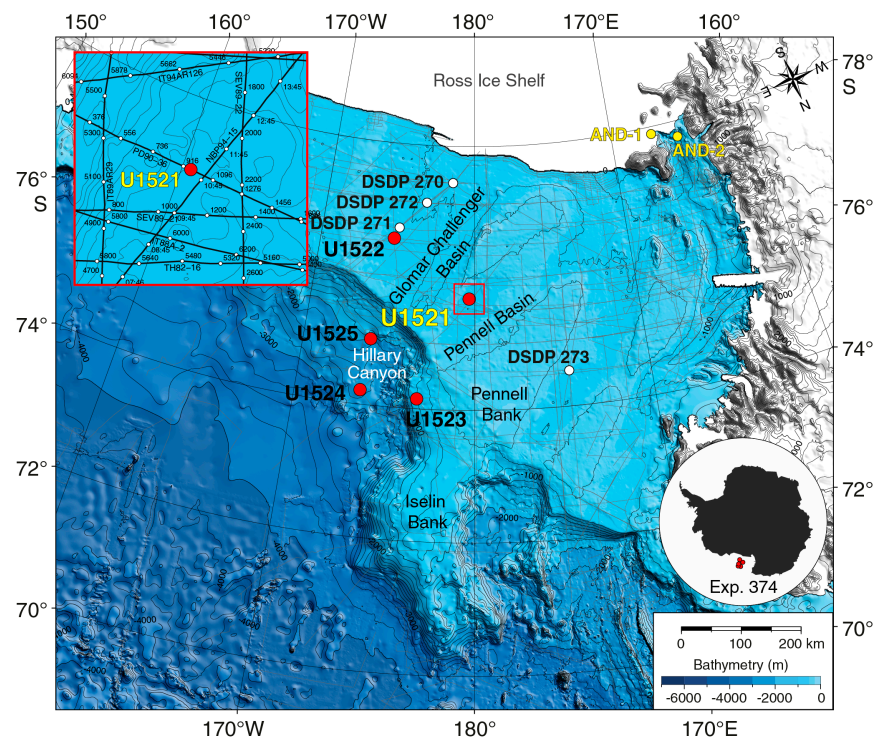

terpreted to represent a cross-shelf expansion of the EAIS in the central regions of the Ross Sea (Brancolini et al., 1995; De Santis et al., 1995). Coring through RSU4 should improve the broad age constraints provided for the unconformity by DSDP Sites 272 and 273 (Bart, 2003).

Records from this site will directly address all five primary Expedition 374 objectives. The record of ice advance and retreat from Site U1521, when integrated with seismic stratigraphy, provenance studies, and numerical modeling, will allow for a more complete assessment of Antarctica's contributions to numerous variations in far-field Miocene sea level (Objective 1) (Miller et al., 2005; John et al., 2011). The magnitude of polar amplification during the MCO will be assessed through proxies for oceanic and atmospheric temperatures derived from both in situ marine organic matter and meltwater-transported terrestrial organic matter (e.g., micropaleontology and lipid biomarkers) (Objective 2). Insights into the oceanic drivers of early Miocene retreat of marine-terminating ice sheets and their subsequent middle to late Miocene readvances can be achieved by detailed lithofacies analysis. This information can be paired with micropaleontological and geochemical proxies to identify the magnitude of the oceanic change and to understand the effect of ocean heat on ice sheet variability (Objective 3 ). Similarly, these methods, when combined with downhole logging results to complete the stratigraphy, will identify the sensitivity of middle Miocene ice sheets to orbital forcing based on the presence of cyclicity in the open-marine, glaciomarine, and glacial proximal sediments (Objective 4). Finally, a "backstripped" paleobathymetry established with accurate dating and depth estimates of the RSU4 surface and other unconformities at Site U1521, in combination with previous drilling constraints from other locations in the Ross Sea, will allow for a fuller assessment of bathymetric controls on AIS evolution.

\section{Operations}

After a $2014 \mathrm{nmi}$ transit from Lyttelton, the vessel arrived at Site $\mathrm{U} 1521$ at $0954 \mathrm{~h}(\mathrm{UTC}+13 \mathrm{~h})$ on 16 January 2018. The original op- 
Figure F10. Top: single-channel seismic-reflection Profile PD90-36 across Site U1521 (see inset in Figure F9) and DSDP Site 273. Profile (air gun 2.4 I) collected by Rice University, TX (USA), in 1990 (Anderson and Bartek, 1992). Bottom: interpretation of seismic reflectors and RSU4 in top panel. Arrows = reflector termination.
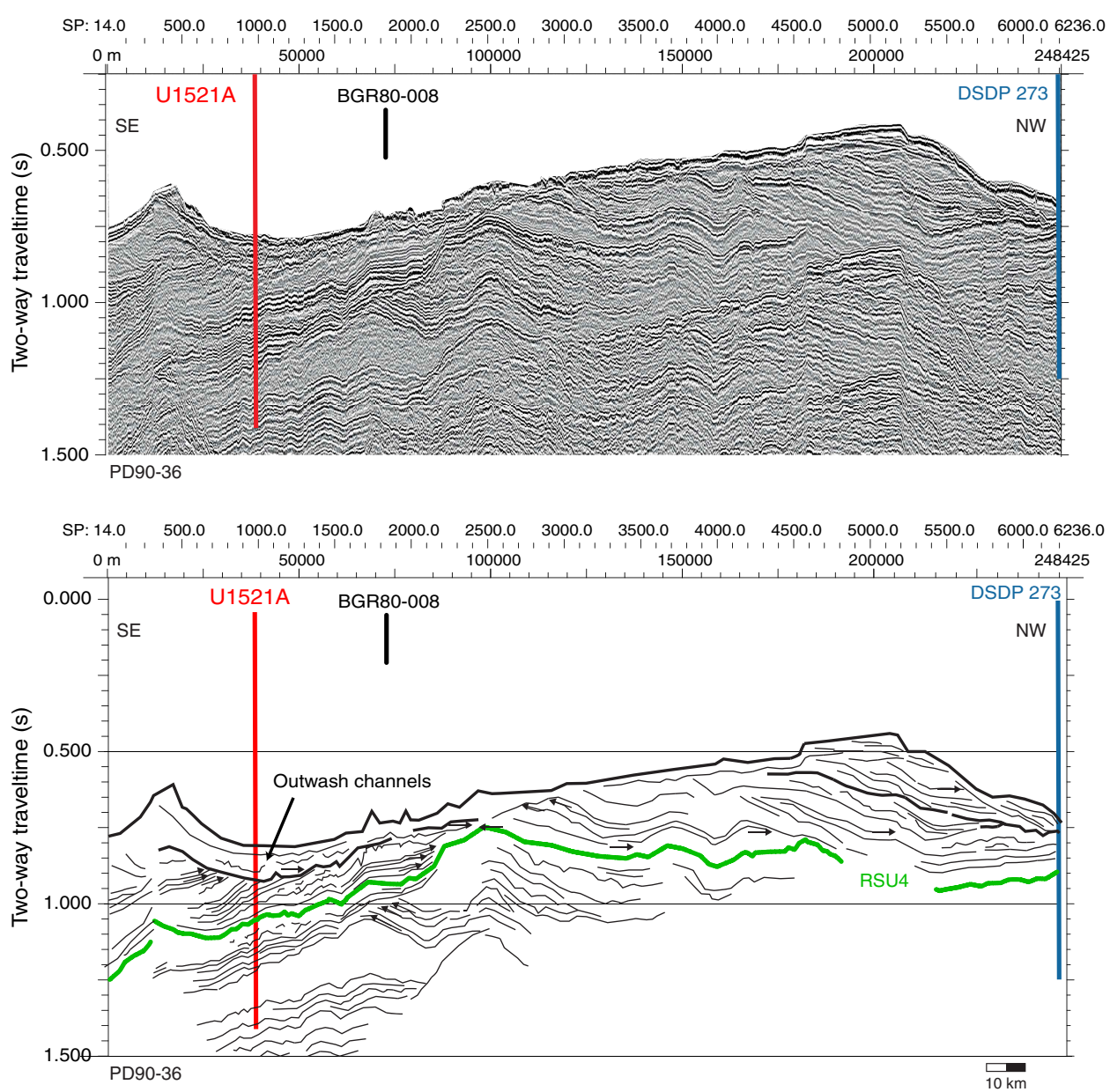

erations plan for Site U1521 called for a single rotary core barrel (RCB) hole to $950 \mathrm{~m}$ drilling depth below seafloor (DSF) and downhole logging with the triple combination (triple combo), Formation MicroScanner (FMS)-sonic, and Vertical Seismic Imager (VSI) tool strings. We ultimately cored Hole U1521A to $650.1 \mathrm{~m}$ DSF (Cores 374-U1521A-1R through 71R) (Table T2). Coring proceeded without incident through Core 37R (0-352.5 m DSF); however, after poor recovery in Cores 32R through 37R (14.49 m; 25\%) caused by jamming of the core barrel with clasts, we switched to cutting halflength cores to improve core recovery. Cores 38R through 43R (352.5-381.3 m DSF) were collected using a $4.8 \mathrm{~m}$ advance (instead of $9.6 \mathrm{~m}$ ), which significantly improved recovery (80\%). We switched back to $9.6 \mathrm{~m}$ advances after the formation became less indurated and continued to core with the RCB system from Core 44R through Core 71R (381.3-650.1 m DSF). We terminated coring at that depth after meeting the primary scientific objectives. At the end of coring operations, we displaced the hole with heavy (10.5 $\mathrm{lb} / \mathrm{gal}$ ) mud and logged with all three tool strings, all of which reached to within $\sim 1 \mathrm{~m}$ of the bottom of the hole. Operations at Site U1521 concluded at $2245 \mathrm{~h}$ on 21 January. A total of $132.75 \mathrm{~h} \mathrm{(5.5}$ days) were spent at Site U1521. RCB coring in Hole U1521A penetrated to $650.1 \mathrm{~m}$ DSF, recovering $411.50 \mathrm{~m}$ of core (63\%).

\section{Principal results}

The $648 \mathrm{~m}$ succession of lower Miocene to recent sediment recovered at Site U1521 is divided into seven lithostratigraphic units (I-VII). Unit VI is further divided into Subunits VIA-VIC (Figure F11). Contacts between lithostratigraphic units at Site U1521 range from sharp to gradational. Mudstone and diamictite account for $\sim 90 \%$ of the recovered core, and minor lithofacies include chert and conglomerate (Figure F11). The assemblage of facies reflects openmarine to ice-proximal depositional environments at this location since at least the early Miocene $(\sim 18 \mathrm{Ma})$.

Lithostratigraphic Unit I (0-7.4 m core depth below seafloor, Method A [CSF-A]) consists of a sequence of unconsolidated olive to dark grayish brown diatom-rich mud with dispersed clasts and gray diatom-bearing sandy mud. Unit II is $\sim 80 \mathrm{~m}$ thick and consists of dark gray massive clast-poor muddy diamictite interbedded with bioturbated diatom-bearing/rich mudstone with dispersed clasts. There are several intervals of physically intermixed diatom-bearing/rich mudstone and diamictite with microfaulting and soft-sediment deformation features. Unit III ( 124 m thick) consists of bioturbated olive gray to greenish gray diatom-bearing/rich mudstone. Some intervals are faintly laminated, and whole bivalve shells and shell fragments are present throughout. Unit IV consists of $\sim 70$ 
Table T2. Hole summary, Expedition 374. DSF = drilling depth below seafloor, APC = advanced piston corer, HLAPC $=$ half-length APC, XCB $=$ extended core barrel, $\mathrm{RCB}=$ rotary core barrel. Download table in CSV format.

\begin{tabular}{|c|c|c|c|c|c|c|c|c|c|c|c|c|c|c|c|}
\hline Hole & Latitude & Longitude & $\begin{array}{l}\text { Water } \\
\text { depth } \\
(\mathrm{m})\end{array}$ & $\begin{array}{c}\text { Penetration } \\
\text { DSF } \\
\text { (m) }\end{array}$ & $\begin{array}{l}\text { Cored } \\
\text { interval } \\
\text { (m) }\end{array}$ & $\begin{array}{l}\text { Recovered } \\
\text { length } \\
(\mathrm{m})\end{array}$ & $\begin{array}{c}\text { Recovery } \\
(\%)\end{array}$ & $\begin{array}{c}\text { Drilled } \\
\text { interval } \\
\text { (m) }\end{array}$ & $\begin{array}{c}\text { Drilled } \\
\text { interval } \\
(N)\end{array}$ & $\begin{array}{c}\text { Total } \\
\text { cores } \\
(N)\end{array}$ & $\begin{array}{l}\text { APC } \\
\text { cores } \\
(N)\end{array}$ & $\begin{array}{l}\text { HLAPC } \\
\text { cores } \\
(N)\end{array}$ & $\begin{array}{l}\text { XCB } \\
\text { cores } \\
(N)\end{array}$ & $\begin{array}{l}\mathrm{RCB} \\
\text { cores } \\
(N)\end{array}$ & $\begin{array}{c}\text { Other } \\
\text { cores } \\
(N)\end{array}$ \\
\hline U1521A & $75^{\circ} 41.0351^{\prime} \mathrm{S}$ & $179^{\circ} 40.3108^{\prime} \mathrm{W}$ & 562.18 & 650.1 & 650.1 & 411.50 & 63.30 & 0.0 & 0 & 71 & 0 & 0 & 0 & 71 & 0 \\
\hline U1522A & $76^{\circ} 33.2262^{\prime} S$ & $174^{\circ} 45.4652^{\prime} W$ & 557.60 & 701.8 & 701.8 & 279.57 & 39.84 & 0.0 & 0 & 76 & 0 & 0 & 0 & 76 & 0 \\
\hline U1523A & $74^{\circ} 9.0172^{\prime} \mathrm{S}$ & $176^{\circ} 47.7067^{\prime} \mathrm{W}$ & 828.02 & 46.3 & 46.3 & 33.51 & 72.38 & 0.0 & 0 & 7 & 3 & 4 & 0 & 0 & 1 \\
\hline U1523B & $74^{\circ} 9.0179^{\prime S}$ & $176^{\circ} 47.6660^{\prime} \mathrm{W}$ & 827.99 & 164.4 & 121.2 & 45.13 & 37.24 & 43.2 & 2 & 22 & 1 & 13 & 8 & 0 & 0 \\
\hline U1523C & $74^{\circ} 9.0288^{\prime S}$ & $176^{\circ} 47.6680^{\prime} W$ & 827.99 & 43.3 & 0.0 & 0.00 & 0.00 & 43.3 & 1 & 0 & 0 & 0 & 0 & 0 & 0 \\
\hline U1523D & $74^{\circ} 9.0288^{\prime S} \mathrm{~S}$ & $176^{\circ} 47.7087^{\prime} \mathrm{W}$ & 827.97 & 307.8 & 172.8 & 0.90 & 0.52 & 135.0 & 1 & 18 & 0 & 0 & 0 & 18 & 0 \\
\hline U1523E & $74^{\circ} 9.0290^{\prime} \mathrm{S}$ & $176^{\circ} 47.7491^{\prime} \mathrm{W}$ & 827.88 & 130.8 & 84.7 & 54.08 & 63.85 & 46.1 & 8 & 17 & 1 & 16 & 0 & 0 & 0 \\
\hline U1524A & $74^{\circ} 13.0427^{\prime} S$ & $173^{\circ} 38.0185^{\prime} \mathrm{W}$ & 2394.39 & 299.5 & 299.5 & 282.35 & 94.27 & 0.0 & 0 & 34 & 30 & 1 & 3 & 0 & 0 \\
\hline U1524B & $74^{\circ} 13.0440^{\prime} \mathrm{S}$ & $173^{\circ} 37.9834^{\prime} W$ & 2394.16 & 7.7 & 7.7 & 7.76 & 100.78 & 0.0 & 0 & 1 & 1 & 0 & 0 & 0 & 0 \\
\hline U1524C & $74^{\circ} 13.0537^{\prime S}$ & $173^{\circ} 37.9338^{\prime} W$ & 2394.34 & 441.9 & 181.4 & 19.20 & 10.58 & 260.5 & 1 & 19 & 0 & 0 & 0 & 19 & 0 \\
\hline \multirow[t]{2}{*}{ U1525A } & $75^{\circ} 0.0603^{\prime} \mathrm{S}$ & $173^{\circ} 55.2028^{\prime} W$ & 1775.74 & 213.2 & 213.2 & 158.70 & 74.44 & 0.0 & 0 & 33 & 8 & 14 & 11 & 0 & 0 \\
\hline & & & Totals: & 3006.8 & 2478.7 & 1292.70 & & 528.1 & 13 & 298 & 44 & 48 & 22 & 184 & 1 \\
\hline
\end{tabular}

\begin{tabular}{cccccccc}
\hline Hole & Latitude & Longitude & $\begin{array}{c}\text { Date } \\
\text { started } \\
(2018)\end{array}$ & $\begin{array}{c}\text { Time } \\
\text { started } \\
\text { UTC }(\mathrm{h})\end{array}$ & $\begin{array}{c}\text { Date } \\
\text { finished } \\
(2018)\end{array}$ & $\begin{array}{c}\text { Time } \\
\text { finished } \\
\text { UTC }(\mathrm{h})\end{array}$ & $\begin{array}{c}\text { Time } \\
\text { on hole } \\
\text { (days) }\end{array}$ \\
\hline U1521A & $75^{\circ} 41.0351^{\prime} \mathrm{S}$ & $179^{\circ} 40.3108^{\prime} \mathrm{W}$ & 15 Jan & 2057 & 21 Jan & 0945 & 5.53 \\
U1522A & $76^{\circ} 33.2262^{\prime} \mathrm{S}$ & $174^{\circ} 45.4652^{\prime} \mathrm{W}$ & 21 Jan & 1754 & 28 Jan & 0011 & 6.26 \\
U1523A & $74^{\circ} 9.0172^{\prime} \mathrm{S}$ & $176^{\circ} 47.7067^{\prime} \mathrm{W}$ & 28 Jan & 1318 & 29 Jan & 1550 & 1.11 \\
U1523B & $74^{\circ} 9.0179^{\prime} \mathrm{S}$ & $176^{\circ} 47.6660^{\prime} \mathrm{W}$ & 29 Jan & 1550 & 31 Jan & 0440 & 1.53 \\
U1523C & $74^{\circ} 9.0288^{\prime} \mathrm{S}$ & $176^{\circ} 47.6680^{\prime} \mathrm{W}$ & 31 Jan & 0440 & 31 Jan & 1230 & 0.33 \\
U1523D & $74^{\circ} 9.0288^{\prime} \mathrm{S}$ & $176^{\circ} 47.7087^{\prime} \mathrm{W}$ & 31 Jan & 1230 & 2 Feb & 1340 & 2.05 \\
U1523E & $74^{\circ} 9.0290^{\prime} \mathrm{S}$ & $176^{\circ} 47.7491^{\prime} \mathrm{W}$ & 2 Feb & 1340 & 3 Feb & 1647 & 1.13 \\
U1524A & $74^{\circ} 13.0427^{\prime} \mathrm{S}$ & $173^{\circ} 38.0185^{\prime} \mathrm{W}$ & 3 Feb & 2144 & 5 Feb & 2050 & 1.96 \\
U1524B & $74^{\circ} 13.0440^{\prime} \mathrm{S}$ & $173^{\circ} 37.9834^{\prime} \mathrm{W}$ & 5 Feb & 2050 & 6 Feb & 0730 & 0.44 \\
U1524C & $74^{\circ} 13.0537^{\prime} \mathrm{S}$ & $173^{\circ} 37.9338^{\prime} \mathrm{W}$ & 8 Feb & 2100 & 11 Feb & 0535 & 2.36 \\
U1525A & $75^{\circ} 0.0603^{\prime} \mathrm{S}$ & $173^{\circ} 55.2028^{\prime} \mathrm{W}$ & $6 \mathrm{Feb}$ & 1315 & 8 Feb & 1635 & 2.14 \\
\hline
\end{tabular}

$\mathrm{m}$ of dark gray massive diatom-bearing clast-poor sandy diamictite with basalt clasts. Mudstone and diamictite are interbedded at the top and bottom of the unit, and a conglomerate composed of elongated mudstone intraclasts is observed at the base of the unit. Unit $\mathrm{V}$ is a $40 \mathrm{~m}$ interval of poorly recovered chert nodules and silica cemented mudstone. Unit VI ( $245 \mathrm{~m}$ thick) is characterized by interbedded mudstone and diamictite that is divided into three subunits based on the style of interbedding. Subunit VIA ( 56 m thick) consists of interbedded dark gray massive diamictite with silica-cementing and mudstone, whereas Subunit VIB ( $\sim 60 \mathrm{~m}$ thick) consists of massive to stratified dark gray sandy diamictite with shell fragments, calcium carbonate nodules, and three intervals of clastsupported conglomerate. Subunit VIC ( 128 m thick) is a sequence of interbedded mudstone with dispersed clasts and sandy diamictite with carbonate concretions and shell fragments. Unit VII consists of $\sim 70 \mathrm{~m}$ of interbedded massive to stratified sandy diamictite.

Micropaleontological investigation included examination of core catcher samples and additional samples from split core sections for diatoms, radiolarians, foraminifers, calcareous nannofossils, and palynomorphs (including dinocysts, pollen, and spores) to obtain biostratigraphic ages and preliminary paleoenvironmental information. The presence and abundances of the microfossil groups vary significantly throughout the recovered sediment column (Figure F11). Rich assemblages of diatoms are present in the upper $\sim 280 \mathrm{~m}$ CSF-A. Below that depth, diatoms are altered to opal-CT or are poorly preserved and offer minimal biostratigraphic

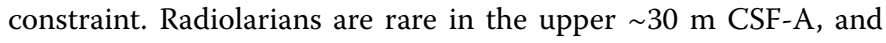
their abundance decreases significantly downhole. Foraminifers and palynomorphs are generally sparse throughout the hole, and calcareous nannofossils are only present in trace numbers deeper than $\sim 525$ m CSF-A. All microfossil group assemblages represent a combination of in situ and reworked taxa of different ages.

Although all investigated microfossil groups provide valuable age and/or paleoenvironmental information, diatoms provide the best age constraints, particularly in the upper $\sim 280 \mathrm{~m}$ CSF-A (Figure F11). Shallower than $75 \mathrm{~m}$ CSF-A, age assignment is difficult because of reworking; however, diatom and radiolarian assemblages suggest a late Pliocene to Pleistocene/recent age for the uppermost $25 \mathrm{~m}$ CSF-A. An unconformity at $\sim 25 \mathrm{~m}$ CSF-A separates Pliocene sediment from middle Miocene sediment. Age-diagnostic diatoms present between $\sim 75$ and $280 \mathrm{~m}$ CSF-A allow assignment of that interval to the Actinocyclus ingens and Denticulopsis maccollumii Zones (middle to early Miocene). Dinocysts and other aquatic palynomorphs confirm this age. Between $\sim 280$ and $380 \mathrm{~m}$ CSF-A, siliceous microfossils are altered to opal-CT. From $\sim 380$ to $580 \mathrm{~m} \mathrm{CSF-}$ A, diatoms are present but preservation is poor, with valves occurring as silicified casts. Despite this lithology, the presence of Thalassiosira sp. cf. Thalassiosira bukryi and absence of Thalassiosira praefraga indicate an early Miocene age. Dinocysts are present over this interval, but the assemblage contains a mix of in situ and reworked taxa. Siliceous microfossils are absent deeper than $580 \mathrm{~m}$ CSF-A, whereas dinocysts and calcareous nannofossils are present and could indicate an early Miocene age if not reworked.

Foraminifers are generally sparse, and the assemblages are dominated by calcareous benthic species. The foraminifer assemblages represent distinct biofacies that vary in parallel with the lithofacies 
Figure F11. Site U1521 summary. Preliminary environmental interpretation is based on microfossils.

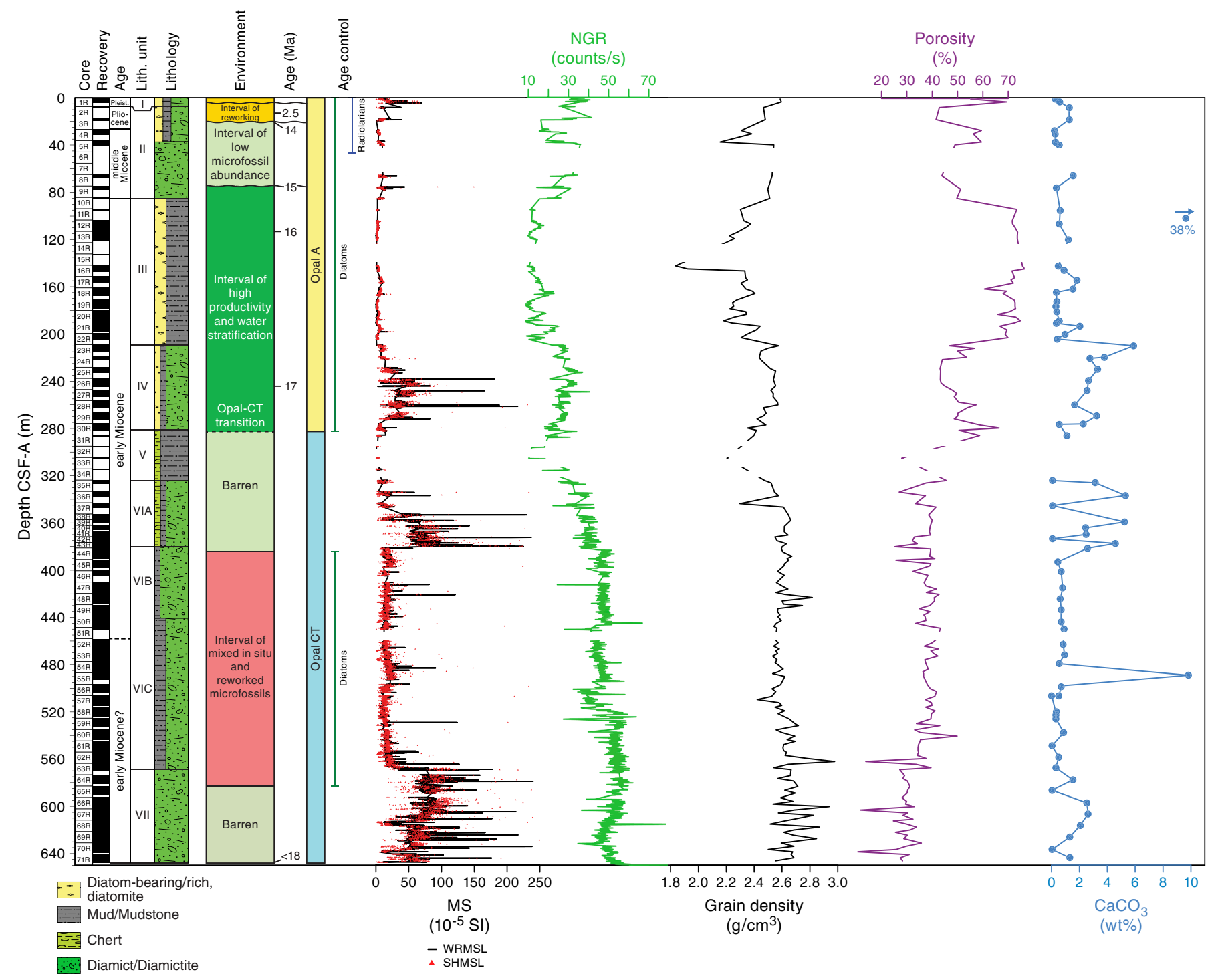

recovered at Site U1521. Well-preserved diatoms and dinocysts indicate a highly productive and seasonally stratified water column between $\sim 75$ and $280 \mathrm{~m}$ CSF-A (early to early middle Miocene). All microfossils will greatly contribute to constraining paleoceanographic and paleoproductivity changes that occurred through the early to middle Miocene in the Ross Sea.

Paleomagnetic investigations focused on measurements of archive-half core sections and oriented discrete (cube) samples. Natural remanent magnetization (NRM) measurements of archive-half core sections were conducted before and after progressive alternating field (AF) demagnetization, commonly in $5 \mathrm{mT}$ increments up to $20 \mathrm{mT}$ peak AF. After $20 \mathrm{mT}$ peak AF demagnetization, NRM intensity usually ranges between $\sim 10^{-4}$ and $10^{-2} \mathrm{~A} / \mathrm{m}$ and varies with lithology. Selected discrete samples were also used for initial NRM measurement, followed by NRM measurements after progressive AF demagnetization in 2-10 $\mathrm{mT}$ increments up to a peak AF of 80 mT. Principal component analysis (PCA) of these measurements reveals a stable characteristic remanent magnetization (ChRM) component in most of the samples, yielding normal and reversed polarities based on inclination data. Steep upward or downward inclinations are also present in most intervals of archive-half core data and agree with directions from discrete samples, suggesting a stable and reliable magnetic carrier that can be used for magnetostratigraphic interpretation. The identified normal and reversed polarity zones can be correlated to the geomagnetic polarity timescale (GPTS) with the aid of biostratigraphic datums.

Discrete samples were also used to measure the anisotropy of magnetic susceptibility (AMS) and mean bulk magnetic susceptibility. The AMS agrees well with variability in the lithostratigraphic units. For instance, AMS shows an oblate fabric that reflects sedimentary compaction in the diatom-bearing/rich mudstone of lithostratigraphic Unit III.

Physical property measurements were conducted on wholeround cores, split core sections, and discrete samples. In general, the whole-round core gamma ray attenuation (GRA) bulk density and magnetic susceptibility measurements show trends similar to those from discrete moisture and density (MAD) samples and point measurements of magnetic susceptibility on the section halves (Fig- 
ure F11). A downhole increase in $P$-wave caliper (PWC) values generally coincides with an increase in bulk density and a decrease in porosity. Downhole variations in natural gamma radiation (NGR) also correlate well to changes in bulk density. Downhole changes in physical property characteristics are in good overall agreement with the lithostratigraphic units, which are defined based on sedimentological characteristics. In general, diatom-bearing/rich mud(stone) lithofacies (lithostratigraphic Units I-III and V) correspond with low magnetic susceptibility, NGR, thermal conductivity $(<1$ $\mathrm{W} /[\mathrm{m} \cdot \mathrm{K}])$, and bulk density and high porosity. The lowest grain density and highest porosity correspond with diatom-bearing/rich mudstone, which is the dominant facies in lithostratigraphic Unit III (Figure F11). In contrast, intervals that are predominantly diamictite (Units II, IV, VI, and VII) are characterized by increased NGR; high bulk density, $P$-wave velocity, and thermal conductivity; moderate to high magnetic susceptibility; and low to moderate porosity. Variations in magnetic susceptibility for clast-poor diamictite (low to moderate) and clast-rich diamictite (variable and generally high) suggest that magnetic susceptibility is an indicator of the abundance of glacially transported clasts or coarse sand in the sediment (Figure F11).

Headspace gas analyses show low methane and ethane concentrations in the upper $40 \mathrm{~m}$ CSF-A at Site U1521, and concentrations increase downhole to $67,000 \mathrm{ppmv}$ methane and 264 ppmv ethane. Interstitial water analyses on 15 samples from the uppermost $\sim 360$ $\mathrm{m}$ CSF-A show a typical diagenetic profile with sulfate reduction and increasing ammonium concentration in the uppermost $76 \mathrm{~m}$ CSF-A. Alkalinity follows a profile similar to that of ammonium, and barium concentration increases deeper than $\sim 76 \mathrm{~m}$ CSF-A. Total organic carbon (TOC), total nitrogen $(\mathrm{TN})$, and carbonate (Ca$\left.\mathrm{CO}_{3}\right)$ contents are generally low $(<1.2,0.1$, and $<6 \mathrm{wt} \%$, respectively) (Figure F11). TOC content is slightly higher in the mudstone facies in the upper $300 \mathrm{~m}$ CSF-A and decreases in the diamictite between $\sim 330$ and $640 \mathrm{~m}$ CSF-A. The TOC/TN ratio suggests mixed input of terrestrial- and marine-derived organic matter with no clear downhole trend. Elevated $\mathrm{CaCO}_{3}$ content is only observed in the sandy diamictite of lithostratigraphic Unit IV, Subunit VIA, and Unit VII, which also have higher magnetic susceptibility. Elemental ratios obtained by handheld portable X-ray fluorescence (pXRF) scans show good agreement with major lithostratigraphic units but also suggest some deviations between chemical and lithologic boundaries.

Downhole logging consisted of three separate tool runs (triple combo, FMS-sonic, and VSI), all of which reached the bottom of the hole and proceeded without issue because of favorable borehole conditions. The triple combo measured NGR, density, porosity, resistivity, magnetic susceptibility, and borehole diameter. The caliper data show that the borehole was in excellent condition, with only one washed out interval between 221 and $226 \mathrm{~m}$ wireline matched depth below seafloor (WMSF). The NGR, bulk density, and porosity data match well with the data from core measurements, whereas the magnetic susceptibility data do not correlate as well, possibly as a result of temperature drift or other issues with the Magnetic Susceptibility Sonde (MSS). The second logging run consisted of the FMS-sonic tool string to measure resistivity borehole images and acoustic velocity. The latter shows good correlation with the data measured with the PWC, especially shallower than $\sim 300 \mathrm{~m}$ CSF-A. The FMS images are extremely well resolved and clearly show clasts in the diamictite intervals and a poorly recovered layered interval of chert and mudstone in lithostratigraphic Unit V. The third logging run was with the VSI tool string (geophone) to conduct a vertical seismic profile (VSP) experiment. Raw check shot data were used in preliminary velocity models for an initial seismic-core-log correlation.

\section{Site U1522}

\section{Background and objectives}

Site U1522 (proposed Site EBOCS-03C) is located in the Glomar Challenger Basin at $76^{\circ} 33.2262^{\prime} \mathrm{S}, 174^{\circ} 45.4652^{\prime} \mathrm{W}$ at $558 \mathrm{~m}$ water depth (Figure F12). During the middle Miocene, this site was located near the western edge of a wide embayment $\sim 80 \mathrm{~km}$ south of the present shelf break. Coring at this site was expected to recover a sedimentary sequence that spans the late middle Miocene to the Pleistocene (coinciding with RSU3 through RSU1). Coring targeted laminated and massive acoustic facies interpreted to be interlayered stratified diamictite/mudstone and diatomite (glaciomarine/open marine) and massive diamictite, respectively (Figure F13).

The upper $\sim 400 \mathrm{~m}(1.2 \mathrm{~s}$ two-way traveltime [TWT]) of sediment consists of tabular units (see Figure F3 in the Site U1522 chapter [McKay et al., 2019a]) that are interpreted to be aggradational subglacial till sheets deposited by a grounded ice sheet (i.e., compacted sediments) during the late Pleistocene (Alonso et al., 1992; De Santis et al, 1995). Underlying the till sheets is $\sim 300 \mathrm{~m}$ of acoustically laminated facies interbedded with lens-shaped layers that are more transparent and interpreted to be glaciomarine or hemipelagic sediments and ice-proximal deposits (Böhm et al., 2009) (Figure F13). This site will enable us to determine if ice sheet-overriding events observed at ANDRILL Site AND-1B beneath the modern Ross Ice Shelf advanced to the shelf edge and will therefore help constrain the AIS contribution to Pliocene sea level lowstands (Objective 1) (Naish et al., 2009; Miller et al., 2012). This site will also provide an opportunity to reconstruct the paleoceanographic and paleoecological conditions during periods of glaciomarine deposition at the outermost Ross Sea continental shelf (Objective 2 ). These sequences, combined with downhole logging to fill in unrecovered sections, are anticipated to provide insights into the orbital controls on marine-based ice sheet extent (Objective 4).

Figure F12. Bathymetric map with locations of Site U1522, other Expedition 374 sites, DSDP Leg 28 Sites 270-273, and ANDRILL Cores AND-1 and AND-2. Red box = location of inset map with Site U1522 on seismic-reflection profile Line I06290-Y2 (Figure F13). Bathymetry from Arndt et al., 2013a, 2013b.

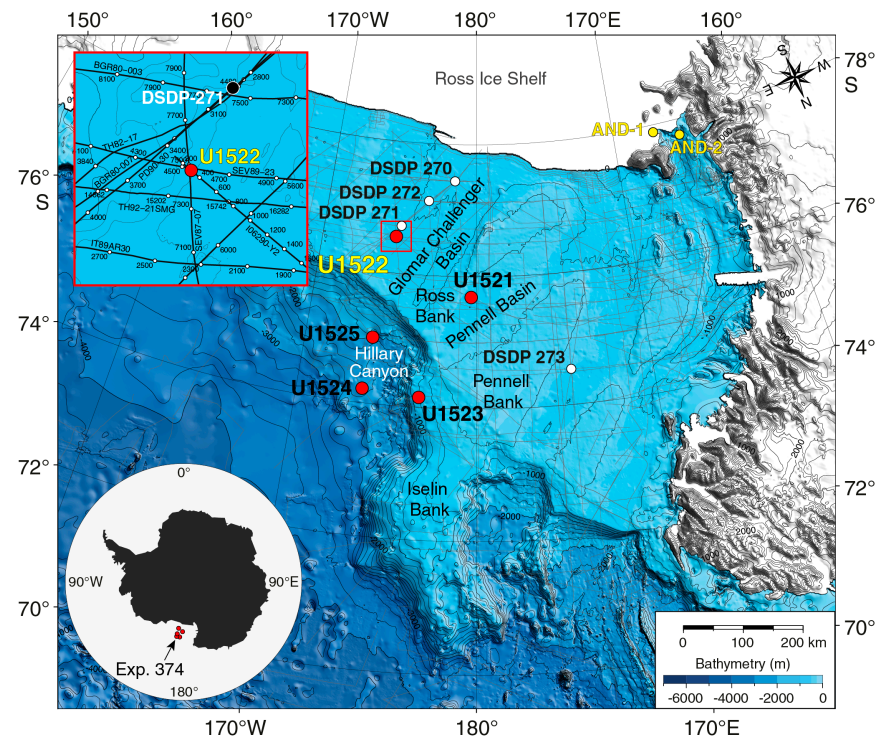


Figure F13. Top: multichannel seismic-reflection Profile 106290-Y2 across Site U1522 (see inset in Figure F12). Profile collected by Istituto Nazionale di Oceanografia e Geofisica Sperimentale (OGS, Italy) under Programma Nazionale delle Ricerche in Antartide (PNRA) in 2005-2006 (Böhm et al., 2009) with a $2 \times$ generator-injector (GI) gun array (11.6 L). Data were acquired with a $600 \mathrm{~m}$ streamer ( 48 channels; first offset $=50 \mathrm{~m}$ and last offset $=650 \mathrm{~m}$ ). Bottom: interpretation of key seismic reflectors in Profile I06290-Y2.

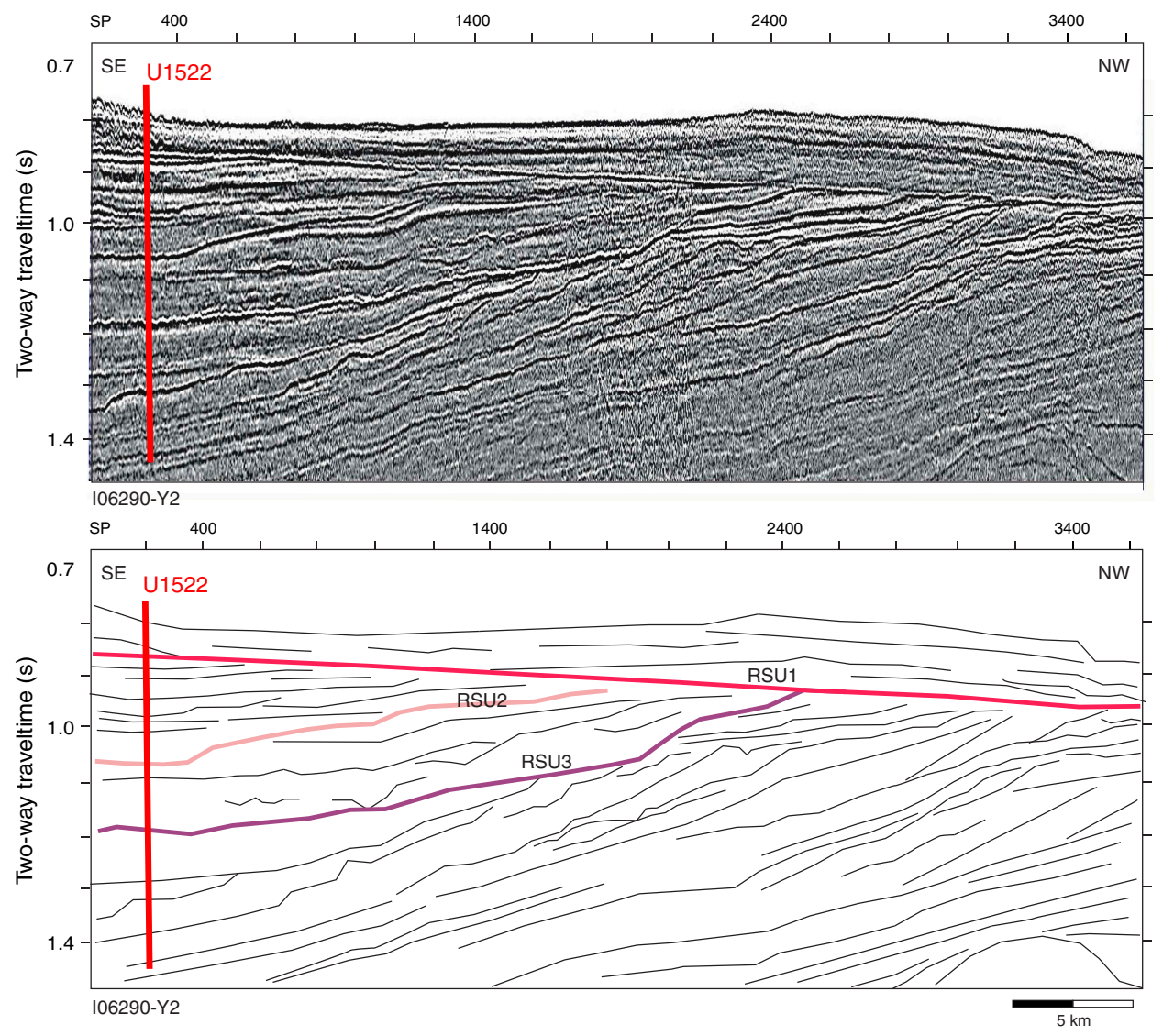

\section{Operations}

After an $88 \mathrm{nmi}$ transit from Site U1521 that averaged $10.7 \mathrm{kt}$, the vessel arrived at Site $\mathrm{U} 1522$ at $0629 \mathrm{~h}(\mathrm{UTC}+13 \mathrm{~h})$ on $22 \mathrm{Janu}-$ ary 2018. The original operations plan consisted of a single RCB hole to $545 \mathrm{~m}$ DSF; however, after requesting and receiving approval from the Environmental Protection and Safety Panel (EPSP) and Texas A\&M Safety Panel, we ultimately cored Hole U1522A to 701.8 m DSF (Cores 374-U1522A-1R through 76R) (Table T2). Core recovery was very poor from 0 to $203.2 \mathrm{~m}$ DSF, was moderate from 203.2 to $424.5 \mathrm{~m}$ DSF, and improved significantly below that depth. Hole cleaning became problematic near the end of coring operations, and off-bottom torque steadily increased despite multiple heavy mud sweeps to clean the hole. At the end of coring operations, the hole was displaced with heavy mud (10.5 lb/gal) and logged with three tool strings: a modified triple combo, the VSI, and the FMS. The Dipole Sonic Imager (DSI) was run on the triple combo instead of with the FMS, and the Hostile Environment Litho-Density Sonde (HLDS) was run without the source to measure borehole diameter with the caliper. Operations at Site U1522 concluded at $1311 \mathrm{~h}$ on 28 January. A total of $149.25 \mathrm{~h}$ (6.2 days) were spent at Site U1522. RCB coring in Hole U1522A penetrated to $701.8 \mathrm{~m}$ DSF and recovered $279.57 \mathrm{~m}$ of core (40\%).

\section{Principal results}

The $695.74 \mathrm{~m}$ succession of upper Miocene to recent sediment cored at Site U1522 is divided into four lithostratigraphic units (I-
IV). Unit III is further divided into Subunits IIIA-IIIC (Figure F14). Several intervals are characterized by very poor recovery that consists primarily of washed gravel and fall-in, which compromises our ability to identify the lithologic variations in some units but may indicate the presence of unrecovered sand- or gravel-rich beds. The dominant facies throughout the cores is massive diatom-bearing/rich diamictite, although some intervals have thin beds of laminated mudstone, carbonate-cemented mudstone, and muddy diatomite.

Lithostratigraphic Unit I consists of $\sim 200$ m of Pleistocene diatom-bearing/rich sandy mud, muddy sand, and clast-rich muddy diamict. The upper $\sim 3 \mathrm{~m}$ of the unit is unconsolidated. Recovery is poor between $\sim 3$ and $\sim 200 \mathrm{~m}$ CSF-A and consists primarily of washed cobbles and gravel resulting from drilling disturbance. A few recovered intervals contain massive diatom-bearing clast-rich muddy diamict. The base of Unit I is defined by increased lithification of the diamict. Unit II consists of $\sim 195 \mathrm{~m}$ of Pliocene massive interbedded diatom-bearing/rich sandy/muddy diamictite with mudstone laminae. Diatom-bearing mudstone and deformed (physically intermixed during deposition) discontinuous laminae to centimeter-scale beds are occasionally present in the muddy diamictite. Unit III $(\sim 250 \mathrm{~m})$ includes upper Miocene muddy diatomite and diatom-bearing/rich diamictite and is divided into three subunits based on the style of interbedding and presence of lithologic accessories. Clasts occur throughout, but clast assemblage and composition changes between subunits. Subunit IIIA consists of massive 
Figure F14. Site U1522 summary. Preliminary environmental interpretation is based on microfossils.

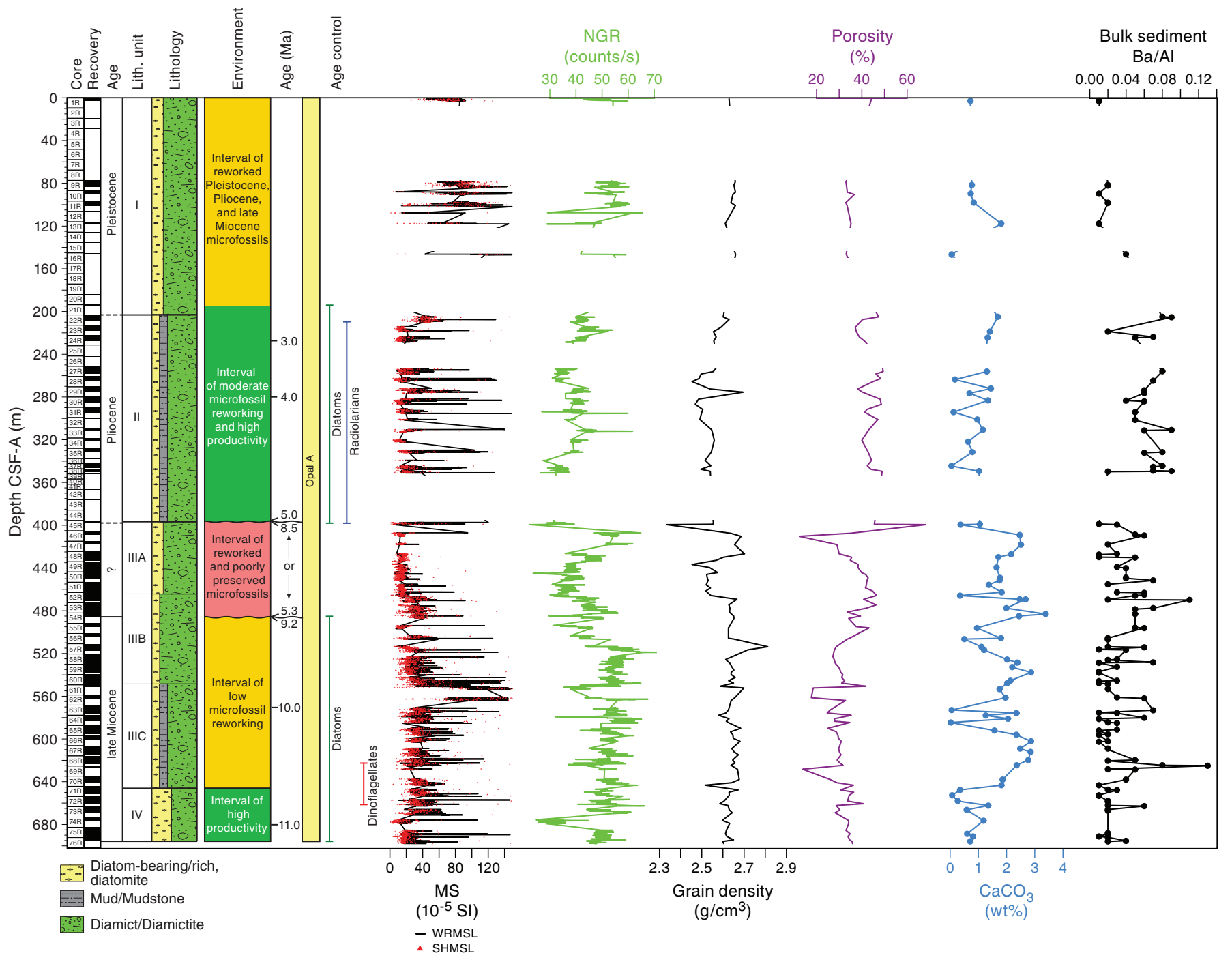

bioturbated muddy diatomite with glauconite and interbedded massive diatom-rich sandy/muddy diamictite with small $(<1 \mathrm{~cm})$ mudstone clasts. Subunit IIIB consists of diatom-bearing sandy/muddy diamictite with intervals of mudstone. Subunit IIIC consists of diatom-bearing sandy/muddy diamictite. Some intervals contain stratification characterized by laminations to thin mudstone beds and changes in matrix color. Although the recovered succession contains diverse clast lithologies throughout, basalt clasts are only common in Subunit IIIC, suggesting a switch in provenance at that time. The base of Subunit IIIC is defined by interbeds of stratified and massive diamictite and diatom-bearing/rich mudstone. Unit IV consists of $\sim 50 \mathrm{~m}$ of upper Miocene interbedded diatom-bearing sandy diamictite and muddy diatomite.

Micropaleontological investigations were performed on all core catcher samples and two additional samples from split core sections to obtain biostratigraphic ages and preliminary paleoenvironmental information through examination of diatom, radiolarian, foraminifer, and palynomorph assemblages. Abundance and preservation of the different microfossil groups strongly varies throughout the sequence. In general, all microfossil groups are rare and comprise a combination of in situ and reworked taxa in the upper $\sim 200 \mathrm{~m} \mathrm{CSF}$ -
A. Diatoms and radiolarians are more abundant between $\sim 200$ and $400 \mathrm{~m}$ CSF-A, and dinoflagellates are common in the lower part of that interval. Deeper than $\sim 400 \mathrm{~m}$ CSF-A, radiolarians are absent and palynomorphs and foraminifers are sparse. The diatom assemblage between $\sim 400$ and $480 \mathrm{~m}$ CSF-A is poorly preserved and primarily reworked, whereas deeper than $\sim 480 \mathrm{~m}$ CSF-A, diatom assemblages are mixed, with a few intervals of well-preserved diverse assemblages interspersed with mostly fragmented sparse assemblages (Figure F14).

The mudline sample contains a modern low-diversity radiolarian assemblage that is typical of the Antarctic continental shelf and includes mainly Antarctissa spp. together with significant numbers of Rhizoplegma boreale and the Phormacantha hystrix/Plectacantha oikiskos group. Below the mudline sample, the upper $\sim 200$ $\mathrm{m}$ CSF-A is tentatively assigned a Pleistocene age; however, the combination of sparse microfossils and mix of in situ and reworked taxa hinders straightforward age assignment and environmental reconstructions (Figure F14). Calcareous benthic foraminifers are represented by few specimens of typical late Neogene Ross Sea shelf species, although many of the specimens are likely reworked. One sample at $\sim 135 \mathrm{~m}$ CSF-A contains a well-preserved assemblage that 
includes the planktonic foraminifer Neogloboquadrina pachyderma.

The interval between 200 and $400 \mathrm{~m}$ CSF-A is assigned a Pliocene age based on diatoms and radiolarians, which were critical for providing age constraints at this site (Figure F14). One sample from $\sim 400 \mathrm{~m}$ CSF-A contains well-preserved diatom, radiolarian, and dinocyst taxa that are indicative of high-productivity environmental conditions that were warmer than today. From 400 to $480 \mathrm{~m} \mathrm{CSF-}$ A, microfossil assemblages are sparse and poorly preserved, and reworking makes age assignment and environmental reconstructions difficult. Deeper than 490 m CSF-A, the absence of the diatom Thalassiosira torokina indicates a late Miocene age older than $9 \mathrm{Ma}$. From $\sim 490 \mathrm{~m}$ CSF-A to the base of the cored interval at $695.74 \mathrm{~m}$ CSF-A, diatom and dinocyst assemblages suggest an expanded upper Miocene sequence. A few samples from this interval contain well-preserved, diverse dinocyst assemblages that include the late Miocene species Selenopemphix bothrion (Harland and Pudsey, 2002). This assemblage suggests high productivity, likely with reduced sea ice relative to present day.

Paleomagnetic investigations primarily focused on measurements of archive-half core sections to determine ChRM and construct a magnetostratigraphy. The NRM of most archive-half core sections was measured before and after progressive AF demagnetization, usually in $5 \mathrm{mT}$ increments to $20 \mathrm{mT}$. NRM intensity commonly decreases by approximately one order of magnitude throughout this demagnetization sequence and in general agrees with magnetic susceptibility measured with the Whole-Round Multisensor Logger (WRMSL) and Section Half Multisensor Logger (SHMSL). NRM inclinations are predominantly positive prior to demagnetization and reveal scattered clusters of normal and reversed polarity after $20 \mathrm{mT}$ peak AF demagnetization.

Discrete samples were used to test the fidelity of the archive-half NRM measurements by progressive demagnetization in $2 \mathrm{mT}$ steps to $20 \mathrm{mT}, 5 \mathrm{mT}$ steps to $60 \mathrm{mT}$, and $10 \mathrm{mT}$ steps to $80 \mathrm{mT}$. The NRM directions of a majority of these discrete samples quickly become erratic, but several samples contain a stable direction that matches the archive-half directions. The normal and reversed polarity zones identified in both archive halves and discrete samples cannot yet be confidently correlated to the GPTS with the available biostratigraphic age control; postcruise work to refine the biostratigraphy should improve the correlation. Discrete samples were also used to measure the AMS to determine magnetic fabric characteristics.

Physical property measurements were conducted on all cores collected. In general, the whole-round core bulk density and magnetic susceptibility measurements show trends similar to those from discrete MAD samples and point measurements of magnetic susceptibility on the section halves (Figure F14). Overall, downhole trends in magnetic susceptibility, NGR, bulk density, $P$-wave velocity, and porosity correspond well with the defined lithostratigraphic units. In general, higher magnetic susceptibility corresponds to higher NGR, bulk density, and $P$-wave velocity and lower porosity and is likely related to the dominance of a mud-rich matrix in the diamict/diamictite recovered at this site. NGR, density, and $P$-wave velocity are lower in lithostratigraphic Unit II (diatom-bearing/rich sandy/muddy diamictite) relative to Units III and IV, possibly indicating a change in the clast or matrix composition. In Subunits IIIB and IIIC and Unit IV, variations in physical properties are related to lithology (muddy diatomite and mudstone versus sandy/muddy diamictite) and the relative abundance of diatoms, mud clasts, carbonate nodules, and basalt clasts. In these units, higher magnetic susceptibility, NGR, density, and $P$-wave velocity and lower porosity correspond to higher proportions of basalt and/or metasedimentary clasts and diatom-bearing lithologies. Lower magnetic susceptibility, NGR, density, and $P$-wave velocity and higher porosity correspond to higher proportions of mud clasts, carbonate nodules, and diatom-rich to diatomite lithologies.

Headspace gases are low in the uppermost 100-200 m CSF-A but display variable methane and increasing ethane concentrations from $\sim 200 \mathrm{~m}$ CSF-A to the bottom of the hole. Interstitial water analyses of the mudline and five whole-round samples indicate early diagenesis immediately below the sediment/water interface, with sulfate reduction in the upper $100 \mathrm{~m}$ CSF-A and manganese reduction downhole to $215.40 \mathrm{~m} \mathrm{CSF}-\mathrm{A}$. TOC and $\mathrm{CaCO}_{3}$ contents are generally low $(<0.6$ and $<3.5 \mathrm{wt} \%$, respectively). Carbonate content increases slightly downhole, with generally higher values between $\sim 400$ and 630 m CSF-A (Figure F14). The slightly elevated carbonate content and decreasing TOC/TN ratio between $\sim 400$ and $630 \mathrm{~m}$ CSF-A may suggest more open-marine conditions during deposition of the diamictite of lithostratigraphic Unit III compared with Units I and II. Systematic variations in pXRF data indicate the potential for detailed reconstruction of sediment provenance, particularly in Units II-IV.

Downhole logging consisted of three tool strings: a modified triple combo with the sonic tool and without the source in the density tool, the VSI to conduct a VSP experiment, and the FMS. The modified triple combo tool string measured borehole diameter, NGR, resistivity, sonic velocity, and magnetic susceptibility. It reached $650.3 \mathrm{~m}$ wireline logging depth below seafloor (WSF), or $\sim 50 \mathrm{~m}$ above the bottom of the hole. Caliper data show that the borehole size varied significantly, with numerous washed out intervals and multiple ledges, which resulted in the VSI and FMS tool strings reaching only $297.5 \mathrm{~m}$ WSF.

Despite lower quality borehole conditions than those at Site U1521, downhole data generally match well with results from core measurements. NGR data from downhole logging show good correspondence with NGR data from whole-round cores, whereas corebased $P$-wave velocity consistently underestimates velocity relative to the downhole log data even though the general trends are similar. Alongside other downhole logging data sets, the FMS resistivity images appear to be of reasonable quality and should help assess lithologies in the poorly recovered upper part of the formation. Check shot data were successfully collected at eight depths with the VSI tool (geophone). Raw check shot data were used in preliminary velocity models for initial core-log-seismic integration.

\section{Site U1523}

\section{Background and objectives}

Site U1523 (proposed Site RSCR-14A) is located on the southeastern flank of the Iselin Bank, $\sim 50 \mathrm{~km}$ northwest of the Pennell Basin, at $74^{\circ} 9.02^{\prime} \mathrm{S}, 179^{\circ} 47.70^{\prime} \mathrm{W}$ at $828 \mathrm{~m}$ water depth (Figure F15). The site is on the outermost continental shelf edge and lies beneath the modern-day ASC (Orsi and Wiederwohl, 2009). The targeted sediments are drift deposits characterized by stratified, parallel seismic reflectors with high to medium amplitudes (Figure F16). Undulations in the seafloor and subseafloor reflectors occur toward the top of the bank, $12 \mathrm{~km}$ west of Site U1523, and are interpreted to be from iceberg scouring (see Figure F2 in the Site U1523 chapter [McKay et al., 2019b]). The scour marks crosscut into the youngest strata, and iceberg keels ploughing into this sediment may act to remobilize sediment deposited on the bank. Farther west $(\sim 80 \mathrm{~km})$, 
Figure F15. Bathymetric map with locations of Site U1523, other Expedition 374 sites, DSDP Leg 28 Sites 270-273, and ANDRILL Cores AND-1 and AND-2. Red box = location of inset map with Site U1523 at the intersection of seismic-profile Lines IT17RS-301 and IT94AR-127A (Figure F16). Bathymetry from Arndt et al., 2013a, 2013b.

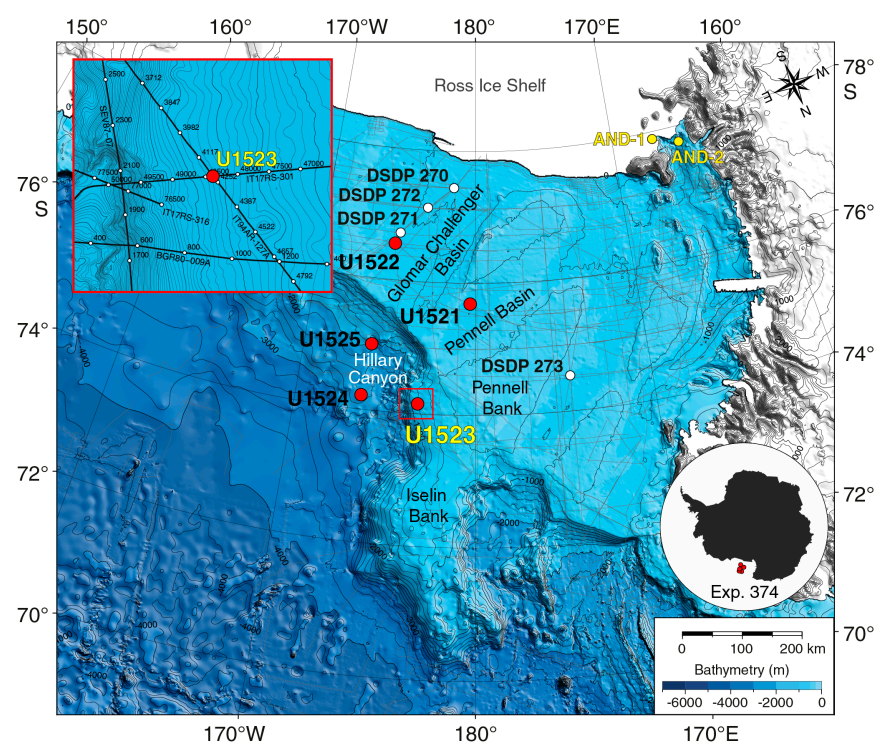

seismic-reflection profiles show flat-topped ridges interpreted to represent grounding-zone wedges (see Figure F4 in the Site U1523 chapter [McKay et al., 2019b]). Ice sheet models suggest that these likely formed during the Last Glacial Maximum as a consequence of eastward ice flow from an ice divide forming on the bathymetric high of the Pennell Bank (Golledge et al., 2013). Consequently, sediment supply at this site could arise from a combination of sources, including

- Icebergs and suspended sediment from the east through the ASC,

- Downslope delivery by glacial outwash and glaciogenic debris flows at the margin of an ice sheet grounded on northernmost Pennell Bank west of the site and remobilized/winnowed by along-slope currents,

- Downslope delivery by suspended sediment scoured by icebergs west of the site, and

- Pelagic/hemipelagic sedimentation.

Bottom currents associated with the ASC in this region are modeled to be between $\sim 10$ and $20 \mathrm{~cm} / \mathrm{s}$ (Padman and Fricker, 2005), and winnowing of fines is expected during periods of enhanced bottom-current flow. Jacobs et al. (1974) reported strong diurnal signals and average and maximum velocities of $>17$ and $>40 \mathrm{~cm} / \mathrm{s}$, respectively, at $4 \mathrm{~m}$ above the seafloor in $527-1201 \mathrm{~m}$ water depth in the Ross Sea.

The primary objective of Site U1523 was to recover a high-resolution record that can be correlated with inner and outer shelf records of ice sheet advance and retreat (e.g., Site U1522 and ANDRILL Site AND-1B; Naish et al., 2009) and used to reconstruct fluctuations in the ASC during the Neogene and Quaternary (Objective 3). Drilling at Site U1523 therefore aimed to sample the upper sedimentary section above RSU4 to achieve this objective. The record of deposition and winnowing beneath the ASC from Site U1523 will enable testing of the hypothesis that changes in the strength of this wind-driven ocean current regulated the southward transport of warm CDW onto the Ross Sea continental shelf during past ice sheet retreat events. Another objective is the reconstruction of ice-proximal oceanic temperatures and surface water properties during periods of pelagic/hemipelagic sedimentation. This reconstruction will constrain the magnitude of polar amplification during past warm periods of the Neogene and Quaternary (Objective 2). An additional objective is to identify processes that govern sediment transfer between the outermost continental shelf and the upper continental slope/rise.

\section{Operations}

After a $147 \mathrm{nmi}$ transit from Site U1522 that averaged $11.5 \mathrm{kt}$, the vessel arrived at Site U1523 at 0158 h (UTC + 13 h) on 29 January 2018. This alternate site was occupied after coring at Site U1522 demonstrated that core recovery would likely be poor in the targeted upper interval of the original proposed primary Site EBOCS04B. We planned to core two holes at Site U1523: one cored with the APC system to refusal, followed by an APC/XCB hole to $450 \mathrm{~m}$ DSF. Instead, we ultimately cored five holes because difficult coring conditions required additional holes to achieve the objectives (Table T2). Prior to coring, we conducted a seafloor camera survey to ensure we could avoid large rocks. The survey included tagging the seafloor at four potential hole locations.

Hole U1523A was cored with a combination of the APC and HLAPC systems to $46.3 \mathrm{~m}$ DSF, where we were unable to land the HLAPC core barrel. The hole was terminated, and we pulled the drill string above the seafloor to try to clean out the bottom-hole assembly (BHA). After we were unable to reestablish circulation through the drill string, we had to pull the pipe back to the surface to clean the debris (rocks and sand/gravel) from the BHA. The debris was curated as a ghost core. The APC/XCB BHA was reassembled and run back to the seafloor, and Hole U1523B was cored to a total depth of $164.4 \mathrm{~m}$ DSF. Toward the end of coring operations in Hole U1523B, hole cleaning became a problem, and off-bottom torque steadily increased despite efforts to clean the hole. In addition, rotary coring with the XCB system yielded very poor recovery, so we terminated operations in Hole U1523B with the intention of using the HLAPC system in Hole U1523C to target specific stratigraphic gaps not recovered in Holes U1523A and U1523B. After pulling clear of the seafloor from Hole U1523B, it became apparent that our ability to circulate through the bit jets was compromised. After attempting to clear the bit jets, we started Hole U1523C and drilled without coring to $43.3 \mathrm{~m}$ DSF. At that depth, we completely lost circulation through the drill string and were forced to terminate operations and pull the drill string back to the rig floor.

We then decided to use the RCB system to core and log to at least $300 \mathrm{~m}$ DSF. Hole U1523D was drilled without coring from the seafloor to $135.0 \mathrm{~m}$ DSF. RCB coring then penetrated from $135.0 \mathrm{~m}$ DSF to a total depth of $307.8 \mathrm{~m}$ DSF. We opted not to deepen the hole farther because of very poor recovery $(0.9 \mathrm{~m} ;<1 \%)$. At the end of coring operations, the hole was displaced with heavy mud (10.5 $\mathrm{lb} /$ gal) and logged with two tool strings: a modified triple combo and the FMS. The DSI was run on the triple combo instead of with the FMS, and the HLDS was run without the source for borehole diameter measurement with the caliper. After logging was completed, we used the APC and HLAPC systems to spot core in Hole U1523E to cover stratigraphic gaps from Holes U1523A and U1523B. Hole U1523E was successfully spot cored to $130.8 \mathrm{~m}$ DSF. After coring was completed, the drill string was recovered, and the 
Figure F16. Multichannel seismic-reflection profile Line IT94AR-127A with location of Site U1523 at the cross point with Line IT17RS-301 (see inset in Figure F15). Profile collected by Istituto Nazionale di Oceanografia e Geofisica Sperimentale (OGS; Italy) under Programma Nazionale delle Ricerche in Antartide in 1994 (I. Finetti et al., unpubl. data). Seismic stack profile is available through the Antarctic Seismic Data Library System for scientific purposes. The source used was a $2 \times 20$ air gun array (74.8 I), and data were acquired with a $1500 \mathrm{~m}$ streamer ( 120 channels; first offset $=164 \mathrm{~m}$ and last offset $=1664 \mathrm{~m}$ ). Reprocessing of Line IT94AR-127A for Expedition 374 was done by Riccardo Geletti (OGS). SP = shotpoint.

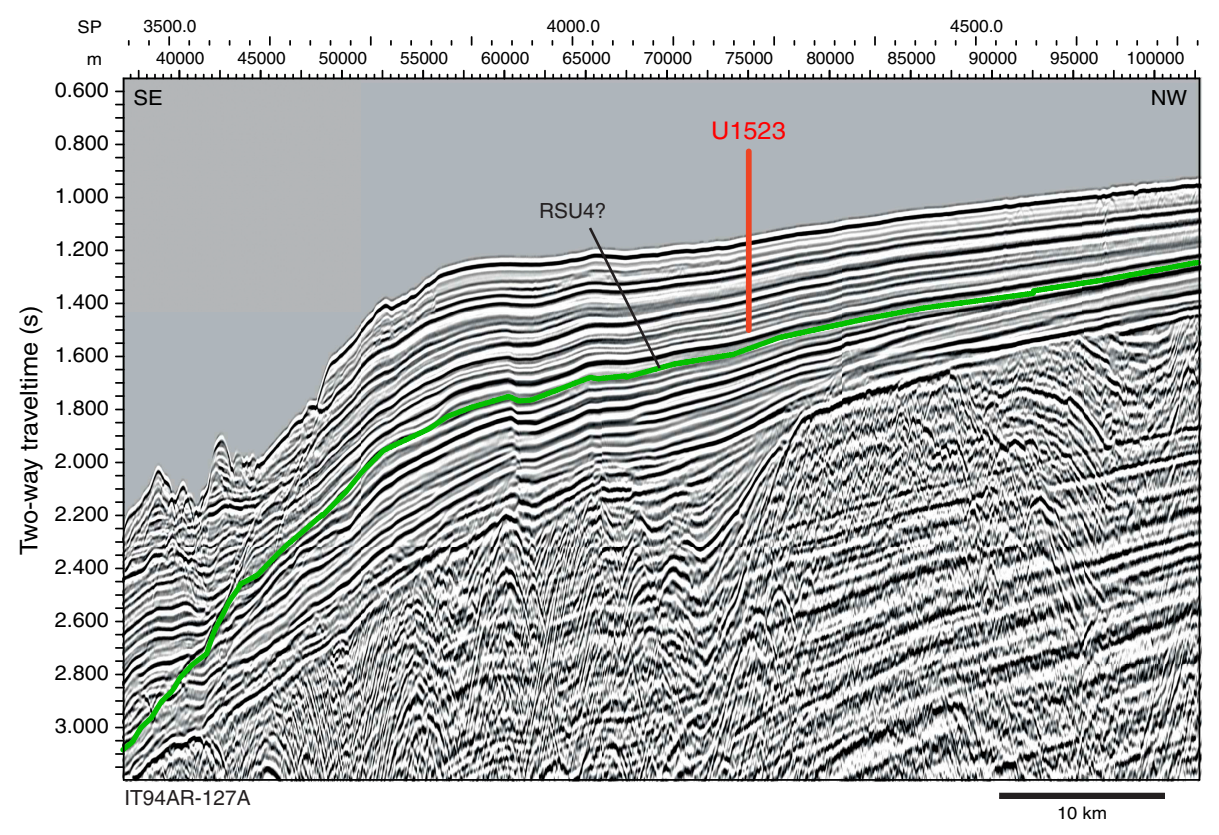

rig floor was secured at $0547 \mathrm{~h}$ on 3 February, ending Hole U1523E and Site U1523. A total of $147.5 \mathrm{~h}$ (6.15 days) were spent at Site U1523.

We collected a total of 64 cores at Site U1523. The APC coring system was deployed 5 times, recovering $41.57 \mathrm{~m}$ of sediment (91\%). The HLAPC coring system was used 33 times, collecting $87.99 \mathrm{~m}$ (59\%). The XCB coring system collected $3.16 \mathrm{~m}$ of core $(5 \%)$ over 8 cores. The RCB system was deployed 18 times over $172.8 \mathrm{~m}$, recovering $0.9 \mathrm{~m}(0.5 \%)$ (Table T2).

\section{Principal results}

The upper $\sim 155 \mathrm{~m}$ of sediment recovered at Site U1523 is divided into three lithostratigraphic units (I-III) dated to the late Miocene-Pleistocene (Figure F17). Deeper than $155 \mathrm{~m} \mathrm{CSF-A,}$ poor recovery in Hole U1523D precluded definition of lithostratigraphic units. Several intervals shallower than 155 m CSF-A are characterized by poor recovery, fall-in, and washed gravel, which compromises our ability to identify lithologic variations and some contacts between units but may indicate the presence of unrecovered sand- and/or gravel-rich beds. Where recovered, the contacts between units are mostly sharp. The major lithologies at Site U1523 are diatom-bearing/rich mud, foraminifer-bearing muddy sand, muddy diatom ooze, and diatom-bearing/rich diamict. These facies reflect open-marine to ice-proximal depositional environments on the outer Ross Sea continental shelf since the late Miocene.

Lithostratigraphic Unit I consists of $\sim 35 \mathrm{~m}$ of Pleistocene massive bioturbated to laminated greenish gray to grayish brown diatom-bearing/rich mud interbedded at the decimeter scale with foraminifer-bearing muddy sand and diamict. Large clasts of diverse lithologies, mud clasts, and pyrite staining occur throughout, and shell fragments and lignite are observed in some intervals. The base of Unit I is defined by a decrease in foraminifer abundance and an increase in diatom abundance. Unit II is a $\sim 60 \mathrm{~m}$ thick sequence of Pliocene to Pleistocene massive to laminated diatom-bearing/rich mud to muddy diatom ooze interbedded at the decimeter to meter scale with massive gray to greenish gray diamict. Glauconite is common in sand beds. Pyrite staining, lithic and mud clasts, shell fragments, bryozoans, and worm tubes were also observed. Unit III includes $\sim 50 \mathrm{~m}$ of upper Miocene massive to laminated pale green, grayish green, and dark gray diatom-bearing/rich mud interbedded at the decimeter scale with greenish gray diatom-bearing diamict. Unit III is similar to Unit II but is distinguished by a decrease in biogenics and an increase in siliciclastics relative to Unit II.

Core catcher samples from Holes U1523A, U1523B, U1523D, and U1523E were examined for siliceous (diatoms, radiolarians, silicoflagellates, ebridians, and chrysophycean cysts), calcareous (foraminifers), and organic (dinocysts and other aquatic palynomorphs, pollen, and spores) microfossils. Diatom remains were encountered in all samples, and radiolarians are generally rare, but several intervals record higher abundance and better preservation that provide important biostratigraphic control, especially for the upper Miocene (Figure F17). A distinctive modern open-ocean radiolarian assemblage is present in the mudline sample of this site, contrasting with the coastal assemblage present in the mudline sample from Site U1522. Organic and calcareous microfossils occur sporadically throughout the entire recovered sequence. Dinocysts are often rare, except in the upper Pliocene and upper Miocene intervals. Foraminifers are most abundant in the upper Pleistocene. A unique monospecific assemblage of agglutinated benthic foraminifers was observed in the upper Miocene of Holes U1523B and U1523E.

Diatoms, radiolarians, and dinocysts provide a sequence of biostratigraphic datums that allow for correlation across holes and development of a composite age model. Three broad stratigraphic intervals separated by disconformities correspond generally to 
lithostratigraphic units and represent deposition of the following intervals (Figure F17):

- An upper Pleistocene interval composed largely of mixed and reworked sediments (corresponding to lithostratigraphic Unit I),

- An upper Pliocene to lower Pleistocene interval (Unit II) with sediment accumulation rates approaching $23 \mathrm{~cm} / \mathrm{ky}$ of diatomrich mud and diatom ooze, and

- An upper middle Miocene to upper Miocene interval (Unit III).

Paleomagnetic analyses focused on constructing a magnetostratigraphy using ChRM directions. The NRM of archive-half core sections was measured before and after progressive AF demagnetization in $5 \mathrm{mT}$ steps to $20 \mathrm{mT}$. NRM intensities prior to demagnetization are mostly $\sim 10^{-1} \mathrm{~A} / \mathrm{m}$ and agree well with WRMSL, SHMSL, and Kappabridge magnetic susceptibility values. This agreement suggests that all of these parameters are approximately equally influenced by magnetic concentration, which seems to be relatively constant throughout all three lithostratigraphic units. NRM inclinations are predominantly positive prior to demagnetization but group in clusters of normal and reversed polarity after AF demagnetization. Discrete samples were used to test the fidelity of the archive-half NRM measurements in a 20 step AF demagnetization sequence. At least three components are present with variable coercivities: a viscous remanent magnetization, a drilling overprint, and a third component with higher coercivity that most likely carries the ChRM.

The normal and reversed polarity zones identified in both archive halves and discrete samples are correlated to the GPTS using constraints from biostratigraphic datums. These tie points allow us to tentatively identify the tops of Subchron C2An.1n and Chrons $\mathrm{C} 2 \mathrm{n}$ and C4An. AMS measurements on discrete samples demonstrate that the magnetic fabric is often oblate. However, $k_{\min }$ inclinations $<60^{\circ}$ also occur and coincide with intervals of coarser grain sizes, suggesting a change in compaction in these intervals relative to fine-grained intervals.

Physical property measurements generally show that wholeround core bulk density, magnetic susceptibility, and $P$-wave velocity measurements are in good agreement with discrete MAD samples and point measurements of magnetic susceptibility and $P$-wave velocity on section halves (Figure F17). Downhole changes in physical properties are in good overall agreement with the defined lithostratigraphic units based on sedimentological characteristics, and changes in physical properties can provide insight into lithologic variations in each unit. Magnetic susceptibility is highly variable in lithostratigraphic Unit I and corresponds to alternating sandy and

Figure F17. Site U1523 summary. Preliminary environmental interpretation is based on microfossils.

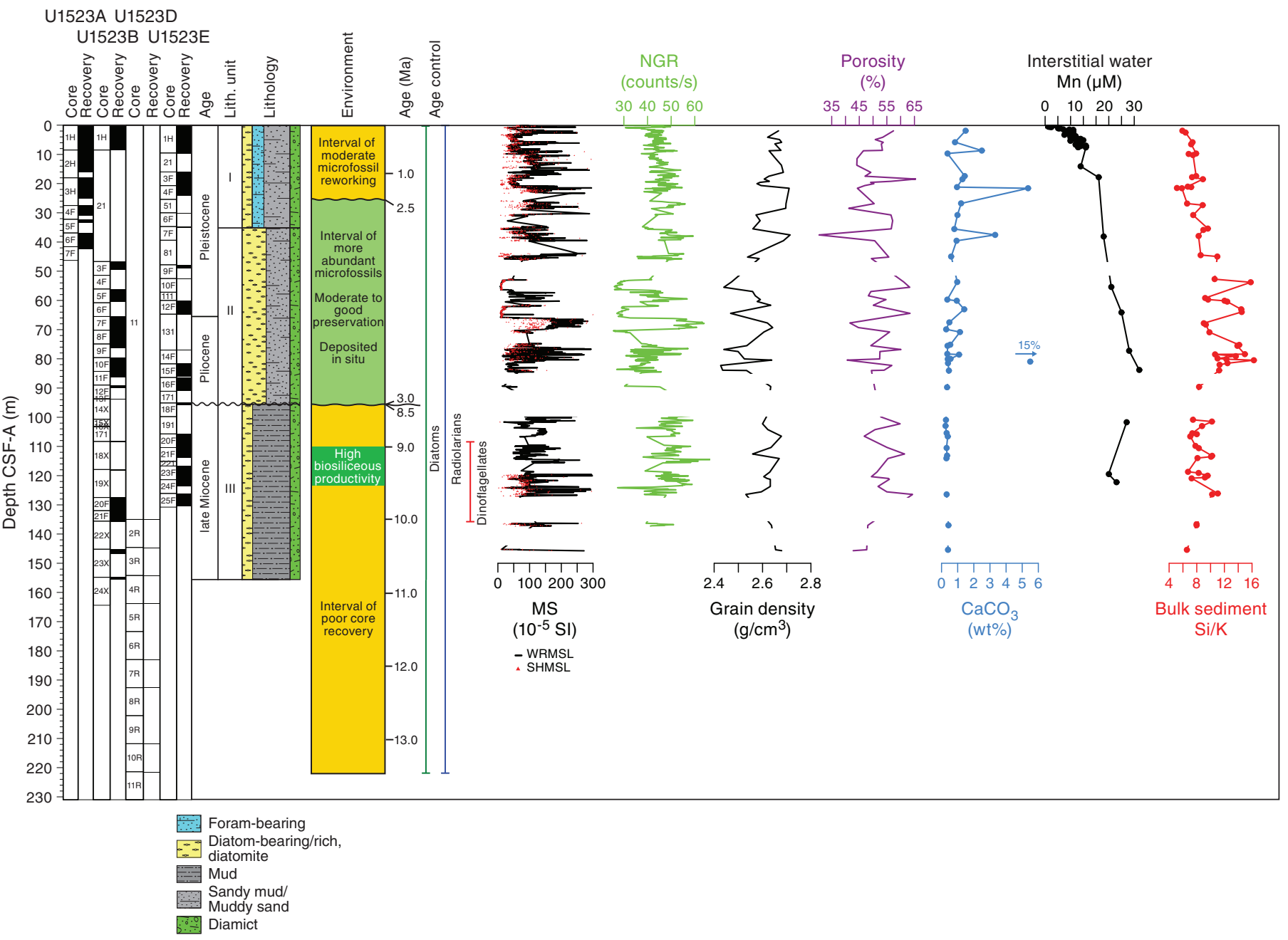


muddy layers with abundant clasts and muddy diamict. Bulk density increases downhole and is anticorrelated with porosity, which decreases downhole in Unit I, suggesting compaction. Deeper than Unit I, bulk density and porosity show significant variation that likely reflects diatom content. For instance, low bulk density, magnetic susceptibility, and NGR in the middle of Unit II $(\sim 60-70 \mathrm{~m}$ CSF-A) correspond to diatom-rich mud intervals. Relatively high and stable NGR measurements in Unit III indicate relatively high clay mineral content in the massive bioturbated to laminated diatom-bearing mud and sandy mud.

Headspace gas concentrations of methane and ethane are close to and below the detection limit, respectively. In addition to lowresolution interstitial water sampling $(\sim 1$ sample per core or every other half-length core) throughout Holes U1523A, U1523B, and U1523E, a high-resolution profile of interstitial water chemistry was obtained for the upper $8.1 \mathrm{~m}$ CSF-A in Hole U1523B. Low-resolution downhole trends suggest manganese and sulfate reduction in the suboxic to anoxic transition zone ( 130 m CSF-A) (Figure F17). Rapid increases in silicon and manganese concentration in the upper $\sim 2 \mathrm{~m}$ probably reflects shallow diagenesis of silica. Bulk sediment $\mathrm{TOC}$ and $\mathrm{CaCO}_{3}$ contents are generally low $(<0.6$ and $<2.5$ $\mathrm{wt} \%$, respectively). TOC content is generally slightly lower in the diatom-bearing mud and diamict of Unit III. Higher carbonate content (up to $\sim 15 \mathrm{wt} \%$ ) is observed in foraminifer-bearing sandy mud in lithostratigraphic Units I and II. The TOC/TN ratio does not display a discernible trend and suggests mixed input of marine and terrestrially derived organic matter. pXRF data indicate lower and more invariant $\mathrm{Ba} / \mathrm{Al}$ ratio compared with Sites U1521 and U1522. In contrast, significant downhole variations are observed in ratios of refractory elements such as $\mathrm{Th} / \mathrm{Ti}$, which alongside ratios like $\mathrm{Fe} / \mathrm{Ti}$ may serve as a provenance proxy at this site (Figure F17).

Downhole logging in Hole U1523D consisted of two tool strings: a modified triple combo with the sonic tool and without the source in the density tool and the FMS. The modified triple combo measured borehole diameter, NGR, resistivity, sonic velocity, and magnetic susceptibility. The modified triple combo tool string reached $292 \mathrm{~m}$ WSF, $\sim 15 \mathrm{~m}$ above the total borehole depth, and the FMS tool string reached $289.6 \mathrm{~m}$ WSF. Downhole logging data will be key for interpreting lithologic variation deeper than $155 \mathrm{~m}$ CSF-A in Hole U1523D, where overall core recovery was very poor $(0.5 \%)$, and in poorly recovered intervals in the upper parts of the site. Although the caliper data identified a number of minor washouts, borehole conditions were reasonable, and the log data show good correspondence with the core data over the $\sim 80 \mathrm{~m}$ of overlap. Interestingly, although the trends and relative changes in magnitude of the NGR log data are similar to those from the cores, the core data are higher than those measured in situ. On the other hand, corebased $P$-wave velocity data are consistently lower than those from the downhole sonic log. The resistivity data show clear alternations of high and low resistivity throughout the borehole that may correspond to alternating layers of fine and coarse sediments. These alterations are also apparent in the FMS resistivity images together with localized high-resistivity spots that are interpreted to be clasts in diamict.

\section{Site U1524}

\section{Background and objectives}

Site U1524 (proposed Site RSCR-10A) is located on the continental rise at $74^{\circ} 13.05^{\prime} \mathrm{S}, 173^{\circ} 37.98^{\prime} \mathrm{W}$ at $2394 \mathrm{~m}$ water depth on the southeastern levee of the Hillary Canyon (Figure F18; see also Figure F3 in the Site U1524 chapter [McKay et al., 2019c]). The levee at
Figure F18. Bathymetric map with locations of Site U1524, other Expedition 374 sites, DSDP Leg 28 Sites 270-273, and ANDRILL Cores AND-1 and AND-2. Red box $=$ location of inset map with Site U1524 on seismic-reflection profile Lines TAN0602_08 (Figure F19) and IT17RS-303B. Bathymetry from Arndt et al., 2013a, 2013b.

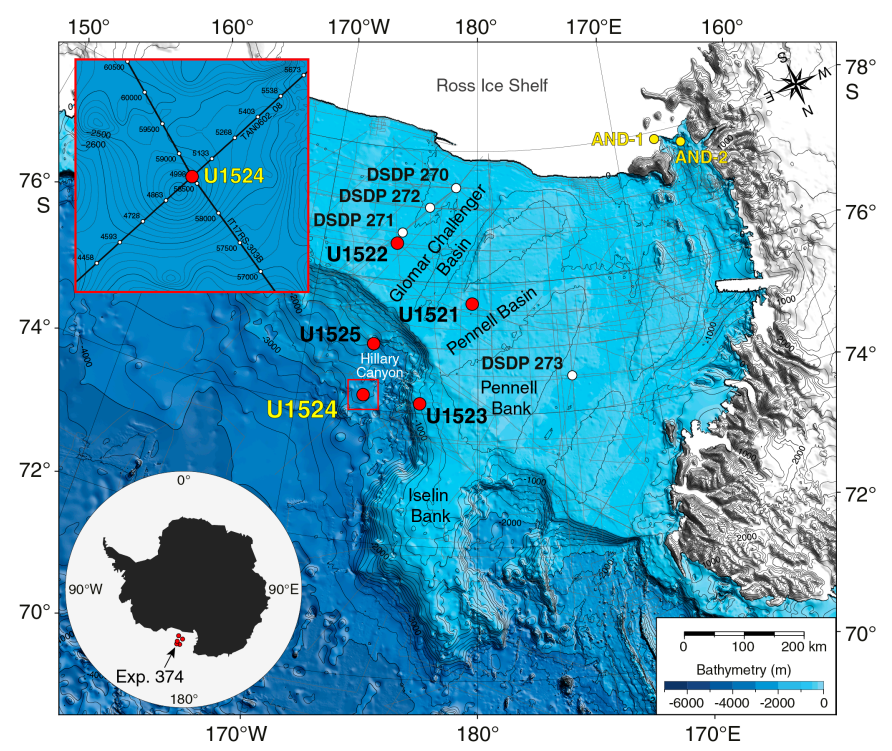

this site has a relief of $\sim 500 \mathrm{~m}$ and is located $\sim 120 \mathrm{~km}$ north of the Ross Sea continental shelf edge. The head of the Hillary Canyon system is located at the mouths of the Pennell Basin and Glomar Challenger Basin. The Hillary Canyon is one of the largest conduits for newly formed Ross Sea Bottom Water (RSBW; a type of AABW), which is focused in this channel by dense water formed on the Ross Sea continental shelf cascading through the troughs and down the continental slope and rise (Bergamasco et al., 2002; Orsi and Wiederwohl, 2009). The site also lies beneath the modern-day westward-flowing ASC (Figure F5). The targeted sediments are interpreted from seismic-reflection profiles to be channel-overspill and drift deposits characterized by stratified, parallel seismic reflectors with high to medium amplitude (Figure F19; see Figure F3 in the Site U1524 chapter [McKay et al., 2019c]).

The primary objectives of Site U1524 were to obtain a near-continuous post-RSU3 (upper Miocene to Pleistocene) and pre-RSU3 (middle to upper Miocene) sediment sequence to provide a highresolution chronology and an ice-distal record of glacial-interglacial cycles. The continental rise location of Site U1524 should allow a more complete assessment of oceanic response to AIS variability. The record of deposition at Site U1524 was anticipated to be primarily influenced by RSBW flowing down the Hillary Canyon. Consequently, this site will enable assessment of the oceanographic influence on ice sheet variability and bottom water production (Objective 2). The direct record obtained at Site U1524 of AABW flow down the Hillary Canyon could potentially be extrapolated to highfidelity paleoceanographic records farther afield in the abyssal $\mathrm{Pa}$ cific Ocean to better constrain the Antarctic influences on the global oceanic deep circulation. The Hillary Canyon is also a main route for glacial sediments eroded and transported by ice streams from the innermost continental shelf to its edge, and provenance studies of the terrigenous sediment may allow for identification of changing ice sheet drainage pathways through the Neogene and Quaternary. Because Site U1524 is near the crest of the levee of the Hillary Canyon, it will also provide a high-resolution record for doc- 
Figure F19. Top: multichannel seismic-reflection Profile TAN0602_08 with Site U1524 (see inset in Figure F18) at the crosspoint with seismic-reflection Profile IT17RS-303B. Profile collected by National Institute of Water and Atmospheric Research (NIWA) and GNS Science in 2006 using the R/V Tangaroa (Lindeque et al., 2016) with a $4 \mathrm{Gl}$ gun array ( $9.8 \mathrm{~L}$ ). Data were acquired with a $300 \mathrm{~m}$ streamer ( 48 channels; near offset nominally $=129 \mathrm{~m}$ and far offset $=422 \mathrm{~m}$ ) towed at a nominal depth of $10 \mathrm{~m}$ below the surface. Bottom: interpretation of key seismic reflectors in Profile TAN0602_08.

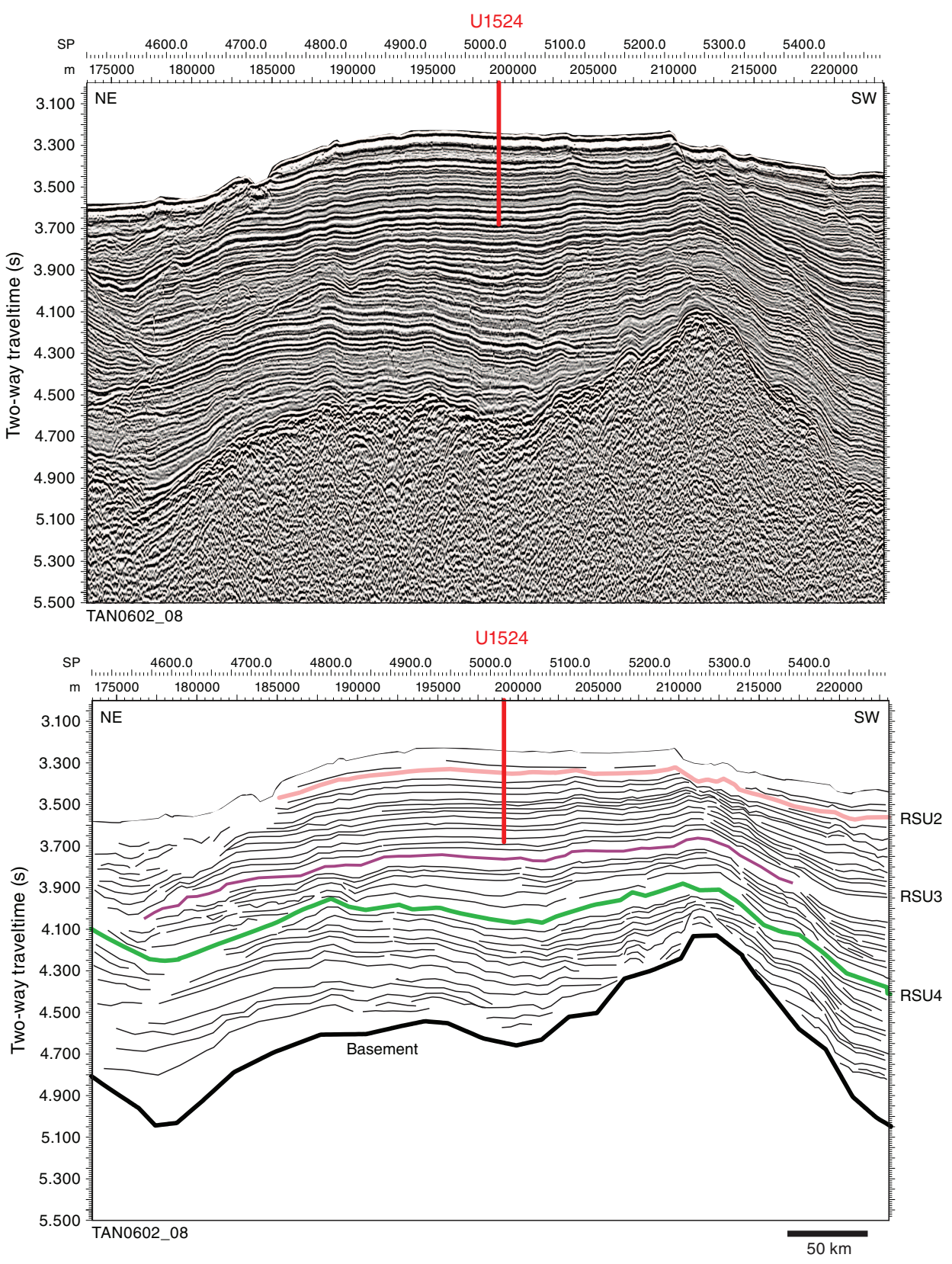

umenting the deep-sea response to ice sheet change on the continental shelf, which is recorded in the Ross Sea inner (ANDRILL Site AND-1B; Naish et al., 2009) and outer (Site U1522) continental shelf. IRD could be sourced by icebergs calving from the Ross Sea and/or transported from the east by the ASC, which provides a proxy for dynamic ice discharge from the Pacific coastline sector of the WAIS. Pelagic sediments deposited during periods of high productivity or a lull in turbidity current overspill deposition will provide a record of surface-water properties, including sea ice cover, SST, stratification, salinity, productivity, and warmer water incursions during superinterglacials. These proxy records will enable us to assess the magnitude of polar amplification during past warm cli- mates (Objective 2) and the role of oceanic forcing of ice sheet retreat or advance at these times (Objective 3). In addition, continuous deposition was anticipated at this site through much of the Neogene and Quaternary to allow for assessment of the orbital response of the WAIS and adjacent oceanic/biological system over a range of past climatic conditions (Objective 4).

\section{Operations}

After a $52 \mathrm{nmi}$ transit from Site U1523 that averaged $11.1 \mathrm{kt}$, the vessel arrived at Site U1524 at $1027 \mathrm{~h}$ (UTC $+13 \mathrm{~h}$ ) on 4 February 2018. This site is an alternate site for primary proposed Site RSCR02B. We decided to occupy the alternate site because the highest 
priority target is shallower, the seismic facies show less evidence for transported sediment, and the sea ice edge was farther away. The original plan called for three holes, one cored to refusal with the APC system followed by an APC/XCB hole to $350 \mathrm{~m}$ DSF. The third hole was to be cored to $1000 \mathrm{~m}$ DSF with the RCB system and then logged with three tool strings. We ultimately cored three holes (Table T2). Hole U1524A was cored with the APC/XCB system to $299.5 \mathrm{~m}$ CSF-A. Hole U1524B consists of a single mudline core collected for high-resolution interstitial water and microbiology sampling. Hole U1524C is an RCB hole cored to $441.9 \mathrm{~m}$ DSF.

Hole U1524A was cored to APC refusal at $270.3 \mathrm{~m}$ DSF, after which we deployed the HLAPC system. The first HLAPC core advanced only $0.4 \mathrm{~m}$ to $270.7 \mathrm{~m}$ DSF, indicating HLAPC refusal. Downhole formation temperatures were taken on Cores 374U1524A-6H (51.5 m DSF), 9H (80.0 m DSF), 12H (108.5 m DSF), and $15 \mathrm{H}$ (137 $\mathrm{m} \mathrm{DSF})$ using the advanced piston corer temperature tool (APCT-3). Following HLAPC refusal, we deployed the XCB system and cored to $299.5 \mathrm{~m}$ DSF, but each XCB core returned with a shattered liner and highly disturbed sediment. At that point, we terminated coring and pulled out of the hole because of approaching sea ice. After pulling out of the hole, enough time remained to collect a single mudline core (Hole U1524B) for high-resolution interstitial water and microbiological studies. After terminating coring in Hole U1524B, we retrieved the drill string and departed Site U1524 at 2030 h on 6 February. With sea ice estimated to remain over Site U1524 for at least 2 days, we opted to occupy Site U1525 (proposed Site RSCR-03A), located only $47 \mathrm{nmi}$ away but in a position south of the sea ice edge. After ice monitoring determined that the sea ice was moving away from Site U1524, we ended operations at Site U1525 at $0535 \mathrm{~h}$ on 9 February to return to Site U1524. After arriving back at Site U1524 at $1006 \mathrm{~h}$, we prepared for RCB coring operations in Hole U1524C. While deploying the drill string, we lowered the subsea camera to retrieve the beacon, which had failed to release when abandoning the site. After retrieving the beacon, Hole U1524C was drilled without coring to $260.5 \mathrm{~m}$ DSF and then RCB cored to $441.9 \mathrm{~m}$ DSF, where we were forced to terminate operations because of a mechanical breakdown of the port stern tube shaft and arrangement that ended Expedition 374 science operations. The rig floor was secured for transit at $1835 \mathrm{~h}$ on 11 February, ending Site U1524. Total time spent at Site U1524 was 117.25 h (4.9 days).

We collected a total of 54 cores at Site U1524. The APC system was deployed 31 times, collecting $284.17 \mathrm{~m}$ of core (102\%). The HLAPC system was deployed once, recovering $0.43 \mathrm{~m}$ of core (108\%). The XCB system collected $5.51 \mathrm{~m}$ over 3 cores (19\%). The RCB system was used 19 times, collecting $19.2 \mathrm{~m}$ of core (11\%) (Table T2).

\section{Principal results}

Site U1524 includes three holes; the deepest hole was cored to $441.9 \mathrm{~m}$ DSF. The recovered upper Miocene to Pleistocene sediment is divided into three lithostratigraphic units (I-III). Unit I is divided into three subunits (IA, IB, and IC) (Figure F20). Contacts between units and subunits are mostly gradational and are distinguished by gradual changes in diatom content. The major lithologies at Site U1524 are diatom-bearing/rich mud/sandy mud, muddy diatom ooze, and muddy diamict. The assemblage of facies reflects pelagic sedimentation with ice rafting and winnowing/redeposition by downslope and along-slope processes. The sediment recovered at Site U1524 reveals current reworking superimposed on variations in siliciclastic and biogenic sediment supply since the late Miocene on the upper continental rise of the Ross Sea.

Lithostratigraphic Unit I consists of $\sim 200$ m of upper Pliocene to Pleistocene unconsolidated interbedded massive to laminated diatom-bearing/rich mud/sandy mud and muddy diatom ooze. A gradual downhole increase in diatom content characterizes this unit and was used to distinguish three subunits based on increasing percentage of biogenic material. Subunit IA consists of $\sim 78 \mathrm{~m}$ of interbedded massive to laminated light yellowish brown to brown diatom-bearing/rich mud and greenish gray diatom-bearing/rich sandy mud with dispersed to common clasts. Sand laminae and lenses are increasingly abundant toward the base of the unit. A 20 $\mathrm{cm}$ thick volcanic ash layer is present in Subunit IA. The base of this subunit is marked by a transition from olive gray diatom-rich mud to interbedded greenish gray diatom-rich mud and sandy mud. Subunit IB ( $78 \mathrm{~m}$ thick) consists of interbedded olive gray and greenish gray diatom-rich mud/sandy mud and muddy diatom ooze with dispersed clasts. Millimeter-scale silty to sandy laminations increase downhole in this subunit. The base of Subunit IB is defined by an increase in thickness and frequency of sandy mud beds. Subunit IC consists of $\sim 45 \mathrm{~m}$ of interbedded olive gray diatom-rich mud and muddy diatom ooze that is similar to Subunit IB but features an increase in the biogenic component, thinner greenish gray diatom-rich mud and muddy ooze, and thicker beds of diatom-rich sandy mud with dispersed clasts. Pyrite staining is present throughout. The boundary between Units I and II is marked by a sharp contact between diatom-rich mud and muddy diatom ooze. Unit II consists of $\sim 117 \mathrm{~m}$ of massive to laminated olive gray muddy diatom ooze interbedded with bioturbated to laminated greenish gray diatom ooze and diatom-rich sandy mud. The olive gray muddy diatom ooze beds include pyrite staining and sand/silt laminations, and the greenish gray diatom ooze beds contain more intense bioturbation. The contact between Units II and III is defined by the first downhole occurrence of massive diamict. Unit III (120 m thick) consists of massive to laminated dark greenish gray mud interbedded with massive greenish gray diatom-rich sandy mud with dispersed clasts of muddy diamict, as well as muddy diatom ooze. The lower contacts of the sandy mud beds are gradational and bioturbated.

A total of 47 core catcher samples from Holes U1524A and U1524C were analyzed for siliceous (diatoms, radiolarians, silicoflagellates, ebridians, and chrysophycean cysts), calcareous (foraminifers), and organic (dinocysts and other aquatic palynomorphs, pollen, and spores) microfossils. The mudline and core catcher samples from Core 374-U1524B-1H were also examined. The occurrence and abundance of the different microfossil groups varies greatly throughout the Site U1524 sediment column. Rich assemblages of diatoms occur throughout, whereas radiolarians are generally rare but common to abundant in several samples, particularly in the lower Pliocene and Miocene intervals where they provide valuable biostratigraphic control (Figure F20). Foraminifers and palynomorphs are generally sparse.

Although all investigated microfossil groups supply valuable information, radiolarians and diatoms provide well-constrained agediagnostic taxa that were used to develop an age-depth model for the site (Figure F20). Reworking and mixing of diatom assemblages of multiple ages limited the biostratigraphic utility of diatoms from the seafloor to $\sim 80 \mathrm{~m} \mathrm{CSF-A}$. The underlying stratigraphic sequence can be assigned to several biostratigraphic zones that are sometimes bounded by unconformities that also correspond to the lithostratigraphic unit boundaries. The $\sim 80-120$ m CSF-A interval 
Figure F20. Site U1524 summary. Preliminary environmental interpretation is based on microfossils.

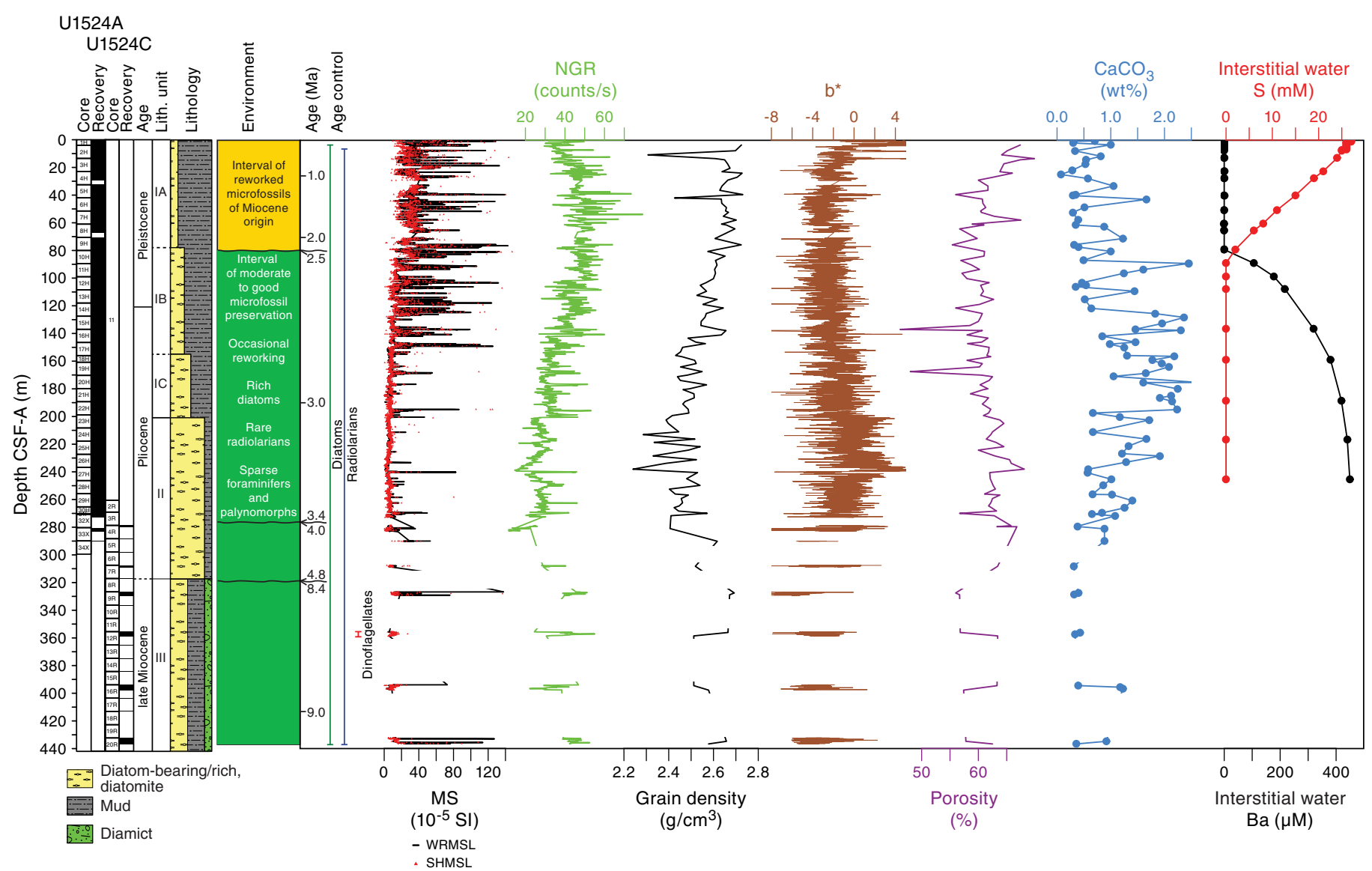

is dated to the early Pleistocene. Deeper than $120 \mathrm{~m}$ CSF-A is an $\sim 160 \mathrm{~m}$ thick Pliocene interval rich in diatoms. A disconformity representing more than 1.0 My is interpreted between $\sim 273$ and 283 $\mathrm{m}$ CSF-A. An $\sim 30 \mathrm{~m}$ thick interval of lower Pliocene sediment between $\sim 283$ and $310 \mathrm{~m}$ CSF-A overlies another disconformity interpreted between $\sim 310$ and $320 \mathrm{~m}$ CSF-A. Sediment deeper than this hiatus is dated to older than $8.5 \mathrm{Ma}$ (late Miocene), and the deepest sample from the site ( 437 m CSF-A) is dated to younger than 10 Ma.

Paleomagnetic investigations primarily focused on generating a magnetostratigraphy to assist with establishing a chronostratigraphy. NRM measurements were generally conducted prior to and after AF demagnetization with peak fields of 10 and $20 \mathrm{mT}$. Initial NRM intensities oscillate around $\sim 10^{-1}$ to $10^{-3} \mathrm{~A} / \mathrm{m}$ and decrease after demagnetization to $\sim 10^{-2}$ to $10^{-5} \mathrm{~A} / \mathrm{m}$. These oscillations agree well with variations in magnetic susceptibility, suggesting that magnetic particle concentration has a comparable effect on these parameters and potentially decreases downhole. After removal of the drilling-induced, downward-directed overprint, inclinations cluster in generally steep upward and downward directions. These clusters represent normal and reversed polarity zones, respectively, that can be tied to the GPTS using independent biostratigraphic datums. We identified all normal and reversed (sub)chrons between Chron C1n (Brunhes; 0-0.781 Ma) and the top of Subchron C2An.2r (3.207 Ma). Magnetic fabric experiments were also conducted to check for subtle disturbances that may yield unreliable directions and for differential compaction in the different lithostratigraphic units. Gen- erally, most samples have an undisturbed oblate fabric, which is common in sedimentary settings, but the degree of anisotropy is variable between lithostratigraphic units and may relate to factors such as differences in sedimentation rate.

Physical properties measurements were conducted on wholeround cores from Holes U1524A and U1524C, with additional measurements on split-core sections and discrete samples. In general, data from whole-round measurements show trends similar to those from split-core measurements. A small deviation between wholeround measurements of GRA bulk density and $P$-wave velocity compared with discrete measurements deeper than $\sim 100 \mathrm{~m} \mathrm{CSF}-\mathrm{A}$ in Hole U1524A is likely due to core expansion generated by degassing during the equilibration of the cores to room temperature. Downhole changes in physical properties are in good overall agreement with the defined lithostratigraphic units based on sedimentological characteristics, and changes in physical properties can provide insight into lithologic changes in each unit.

Overall, there is a good correlation between magnetic susceptibility, NGR, and bulk density measurements (Figure F20). These parameters are inversely correlated with the sediment color $b^{*}$ parameter and appear to relate to diatom content, with a general increase downhole over tens of meters, together with variability caused by interbedded lithologies. Taken together, these results suggest that sedimentary deposition is governed by variations in biogenic and terrigenous inputs. Apparent cyclicity is observed in these parameters. Overall, these parameters suggest a higher terrigenous content in lithostratigraphic Subunit IA, decreasing terri- 
genous content and increasing biogenic content throughout Subunits IB and IC, and maximum biogenic content in Unit II, which is predominantly diatom ooze. Lithostratigraphic Unit III also has higher terrigenous content corresponding to interbedded diatom-rich mud. Downhole formation temperature measurements with the APCT-3 indicate a geothermal gradient of $58^{\circ} \mathrm{C} / \mathrm{km}$, which when combined with thermal conductivity measured on sediment cores from Site U1524 indicates a heat flow of $53.7 \mathrm{~mW} / \mathrm{m}^{2}$.

Headspace gas concentrations of methane and ethane are close to or below the detection limit in the uppermost $\sim 100 \mathrm{~m} \mathrm{CSF-A} \mathrm{at}$ Site U1524 but increase to higher concentrations at greater depths (to 42,000 ppmv of methane at $180 \mathrm{~m}$ CSF-A). Interstitial water sampling was conducted at low resolution $(\sim 1$ sample per core in the upper $100 \mathrm{~m}$ CSF-A and approximately every third core downhole from that depth, depending on core recovery) in Holes U1524A and U1524C. A high-resolution interstitial water profile was also obtained for the upper 7.56 m CSF-A in Hole U1524B. Low- and high-resolution interstitial water profiles show clear manganese and sulfate reduction in the suboxic to anoxic transition zone in the upper $\sim 90 \mathrm{~m} \mathrm{CSF-A} \mathrm{(Figure} \mathrm{F20).} \mathrm{A} \mathrm{rapid} \mathrm{increase} \mathrm{in} \mathrm{silicon} \mathrm{and} \mathrm{man-}$ ganese concentration in the upper $2 \mathrm{~m}$ CSF-A probably reflects shallow diagenesis of silica. Elevated barium concentration deeper than 90 m CSF-A may indicate barite dissolution in an environment where interstitial water is undersaturated with respect to barium. Bulk sediment TOC and $\mathrm{CaCO}_{3}$ contents are generally low throughout the site but reveal distinct variability in lithostratigraphic Unit I. Higher percentages of carbonate content were observed in Subunits IB and IC and in a carbonate-cemented mudstone in Unit III. TN content in the bulk sediments is very low, and the TOC/TN ratio displays similar trends to TOC.

\section{Site U1525}

\section{Background and objectives}

Site U1525 (proposed Site RSCR-03A) is located on the continental slope at $75^{\circ} 0.06^{\prime} \mathrm{S}, 173^{\circ} 55.20^{\prime} \mathrm{W}$ at $1776 \mathrm{~m}$ water depth on the southeastern levee of the Hillary Canyon in a depositional setting similar to that of Site U1524 ( $\sim 87 \mathrm{~km}$ northeast) (Figure F21). Site U1525 is closer to the continental shelf edge, which lies $\sim 60 \mathrm{~km}$ south of the site, and the mouths of the Pennell Basin and the Glomar Challenger Basin. The levee shows asymmetric flanks: a steep northeastern erosional flank with a relief of $\sim 500 \mathrm{~m}$ and a less steep southwestern flank with a relief of only $30 \mathrm{~m}$. The northwest flank sharply truncates parallel high-amplitude reflectors outcropping at the seafloor, and chaotic seismic facies suggest that slope failure features affect the mid- to lower units of the seismic-reflection profile (Figure F22).

The Hillary Canyon is one of the largest conduits for newly formed RSBW, which is focused in this channel by cascading dense water formed on the Ross Sea continental shelf passing down the continental rise (Bergamasco et al., 2002). The site also lies beneath the modern-day westward-flowing ASC (Figure F5), which is thought to be stronger here than at the deeper water Site U1524 (Whitworth et al. 1995; Orsi and Wiederwohl, 2009). Seismic-reflection profiles indicate that the targeted sediments at Site U1525 are dominated by channel-overspill and drift deposits characterized by stratified parallel seismic reflectors with high to medium amplitude (Figure F22; see also Figure F22 in the Site U1525 chapter [McKay et al., 2019d]). These strata in the upper $~ 50 \mathrm{~m}$ CSF-A of the site are likely glacial debris flows interlayered with interglacial hemipelagic units of Pleistocene age that formed a prograding shelfmargin trough-mouth fan at the mouth of the Glomar Challenger
Figure F21. Bathymetric map with locations of Site U1525, other Expedition 374 sites, DSDP Leg 28 Sites 270-273, and ANDRILL Cores AND-1 and AND-2. Red box = location of inset map with Site U1525 on seismic-reflection profile Line IT94AR-127 (Figure F22). Bathymetry from Arndt et al., 2013a, $2013 \mathrm{~b}$.

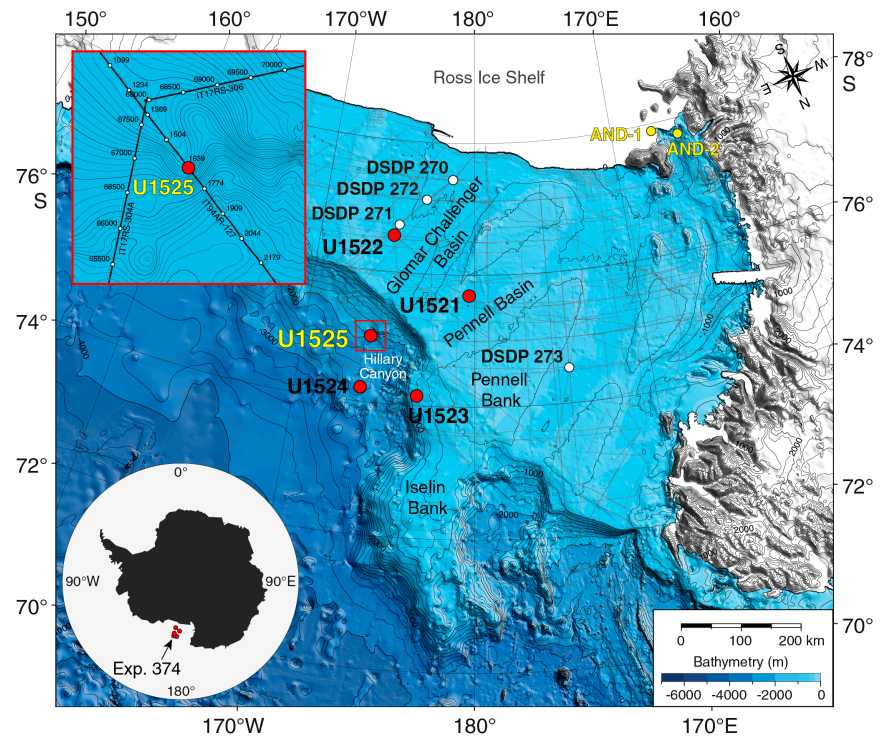

Basin since the late Miocene (RSU3). The objective of Site U1525 was to obtain a pre- and post-RSU3 record to provide a high-resolution chronology of an ice distal record of glacial and interglacial cycles.

The continental slope location of Site U1525 should allow for a more complete assessment of oceanic forcing of (and response to) AIS variability. The deposition record from Site U1525 was expected to be primarily influenced by RSBW flowing down the Hillary Canyon, but this signal is modified by an along-slope component associated with the westward-flowing ASC. Consequently, this site will enable assessment of ocean forcing for ice sheet variability and drivers of bottom water production (Objective 2). The direct record of RSBW flow down Hillary Canyon obtained at Site U1525 could potentially be extrapolated to high-fidelity paleoceanographic records farther afield in the abyssal Pacific Ocean to better constrain the Antarctic influences on the global oceanic deep circulation. The Hillary Canyon is also a main route for glacial sediments being eroded and transported by ice streams from the innermost continental shelf. Provenance studies of the terrigenous sediment may allow identification of changing ice sheet drainage pathways through the Neogene and Quaternary.

IRD could be sourced by icebergs from the Ross Sea, as well as those transported from the east by the ASC, providing a proxy for dynamic ice discharge from the Pacific Ocean coastline sector of the WAIS. Pelagic deposits are from periods of high productivity or a lull in turbidity current-overspill deposition and will provide highresolution proxy records of surface water properties, including sea ice cover, SST, stratification, salinity, productivity, and warmer water incursions during Pleistocene superinterglacials. These proxy records will enable assessment of the magnitude of polar amplification during past warm climates (Objective 2) and the role of oceanic forcing of ice sheet fluctuations during those times (Objective 3). In addition, continuous deposition was anticipated through much of the late Neogene and Quaternary at this site, which would allow assessment of the orbital response of the WAIS and adjacent oceanic/biological systems over a range of past climatic conditions 
Figure F22. Top: multichannel seismic-reflection Profile IT94AR-127 across Site U1525 (see inset in Figure F21). Profile collected by Istituto Nazionale di Oceanografia e Geofisica Sperimentale (OGS, Italy) under Programma Nazionale delle Ricerche in Antartide (PNRA) in 1994 (Finetti et al., unpubl. data) with a $2 \times 20$ air gun $(74.8 \mathrm{~L}$ ). Data were acquired with a $1500 \mathrm{~m}$ streamer $(120$ channels; first offset $=164 \mathrm{~m}$ and last offset $=1664 \mathrm{~m})$. The seismic reflection stack profile is available for scientific purposes through the Antarctic Seismic Data Library System. Reprocessing for Expedition 374 was done by Riccardo Geletti (OGS, unpubl.). Bottom: interpretation of key seismic reflectors in Line IT94AR-127.
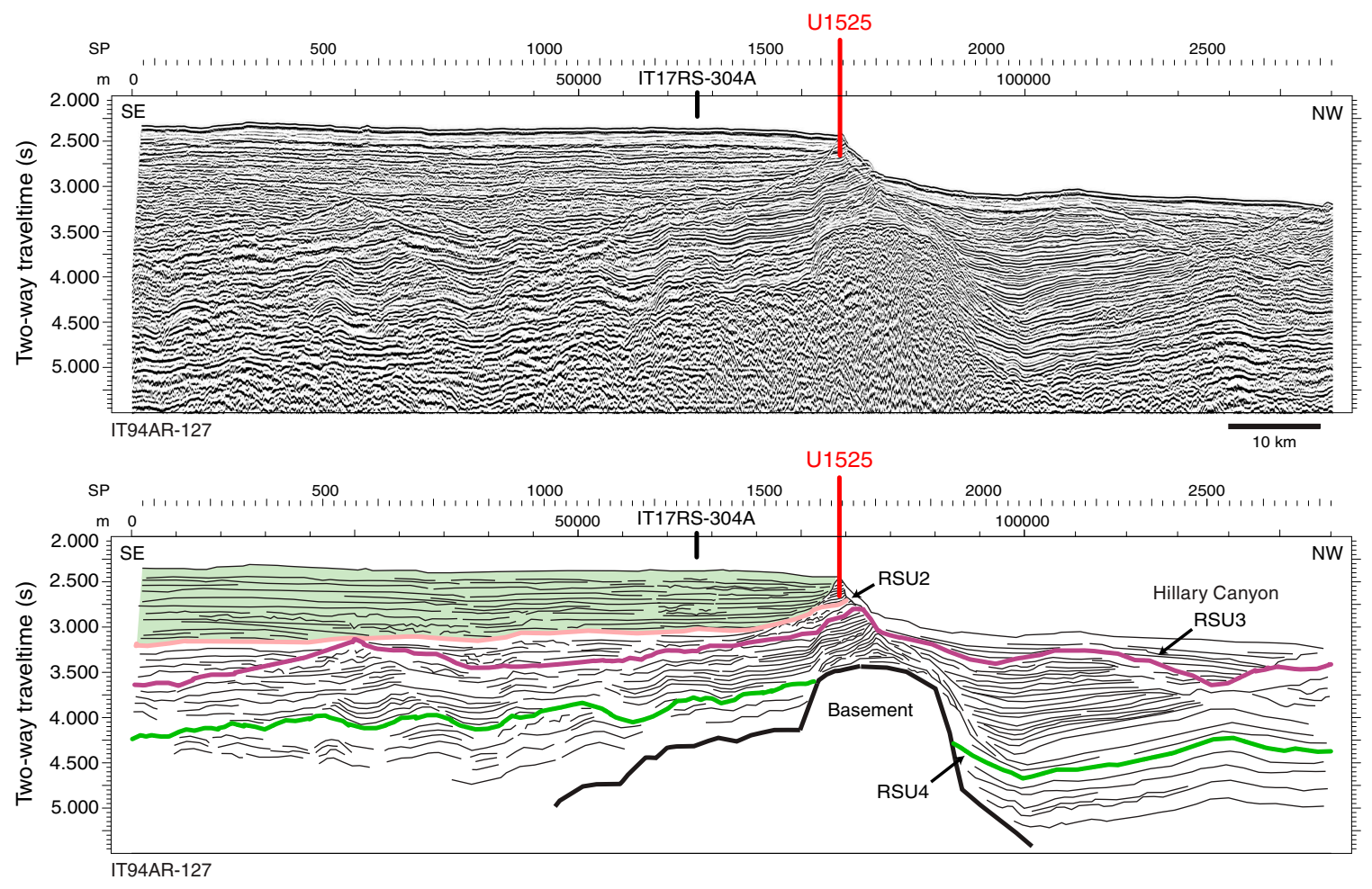

(Objective 4). The late Quaternary record in the uppermost $50 \mathrm{~m}$ of glacial strata can also shed light on recent ice sheet advances.

\section{Operations}

After a $50 \mathrm{nmi}$ transit from Site U1524 averaging $8.9 \mathrm{kt}$, the vessel arrived at Site U1525 at 0200 h (UTC +13 h) on 7 February 2018. This alternate site was added to the schedule when we were forced to temporarily leave Site U1524 because of encroaching sea ice. The operational plan for Site U1525 consisted of APC/XCB coring in a single hole until ice moved away from Site U1524. Hole U1525A was cored to a total depth of $213.2 \mathrm{~m}$ DSF using a combination of APC, HLAPC, and XCB coring (Table T2). The XCB system was deployed in the upper part of the hole (43.0-55.7 m DSF) to core past an indurated interval. We then switched back to piston coring and continued to core using both the APC and HLAPC systems to 131.2 $\mathrm{m}$ DSF. We then continued coring with the XCB system to $213.2 \mathrm{~m}$ DSF and terminated the hole at that depth after receiving confirmation that the sea ice was expected to clear from Site U1524 by the next day. The rig floor was secured for transit at $0535 \mathrm{~h}$ on 9 February to return to Site U1524. A total of 51.25 h (2.1 days) was spent in Hole U1525A.

We collected 33 cores at Site U1525. The APC system was deployed 8 times, collecting $63.23 \mathrm{~m}$ of core (103\%). The HLAPC system was deployed 14 times, recovering $52.64 \mathrm{~m}$ of core $(92 \%)$. The XCB system was used 11 times and collected $42.83 \mathrm{~m}$ (45\%).

\section{Principal results}

Site U1525 cored a single hole to $213.2 \mathrm{~m}$ DSF. The $158.70 \mathrm{~m}$ of recovered Pleistocene sediment is divided into three lithostrati- graphic units (I-III). Unit II is divided into Subunits IIA and IIB (Figure F23). A few intervals (typically $<15 \mathrm{~m}$ in length) are characterized by poor recovery, which compromises our ability to identify lithologic variations. The major facies at Site U1525 are massive to stratified diamict, sand, mud, diatom-bearing mud, and diatom-rich mud to diatom ooze. The assemblage of facies reflects an interplay between distal downslope, along-slope (e.g., winnowing), hemipelagic, and pelagic processes in a relatively ice distal glaciomarine setting. Both thin laminations (millimeter to centimeter scale) and thick beds (meter scale) are recognized in all units and may be linked to glacial dynamics and ocean circulation variations during the Pleistocene.

Lithostratigraphic Unit I consists of $\sim 51 \mathrm{~m}$ of unconsolidated massive bioturbated gray diatom-bearing sandy mud with dispersed clasts interbedded on a meter scale with gray to light yellowish brown clast-poor to clast-rich muddy diamict. Unit I bedding contacts are sharp to gradational. The muddy diamict is overcompacted in some intervals and contains randomly distributed clasts of igneous and metamorphic composition. The base of Unit I is in an interval of poor recovery; however, it is defined by a sharp contact between the overlying diamict and diatom-rich mud. Unit II consists of $\sim 68 \mathrm{~m}$ of massive to laminated greenish gray diatom-bearing/rich mud interbedded at the decimeter to meter scale with diatom-bearing/rich sandy mud. Unit II is divided into two subunits based on diatom abundance and the structure and texture of laminations. Subunit IIA contains well-defined millimeter-scale fine sand, silt, and biosiliceous laminations with sharp lower boundaries and internal normal grading. Clasts, soft-sediment deformation features, and microfaulting are observed in the laminated sequences. 
Figure F23. Site U1525 summary. Preliminary environmental interpretation is based on microfossils.

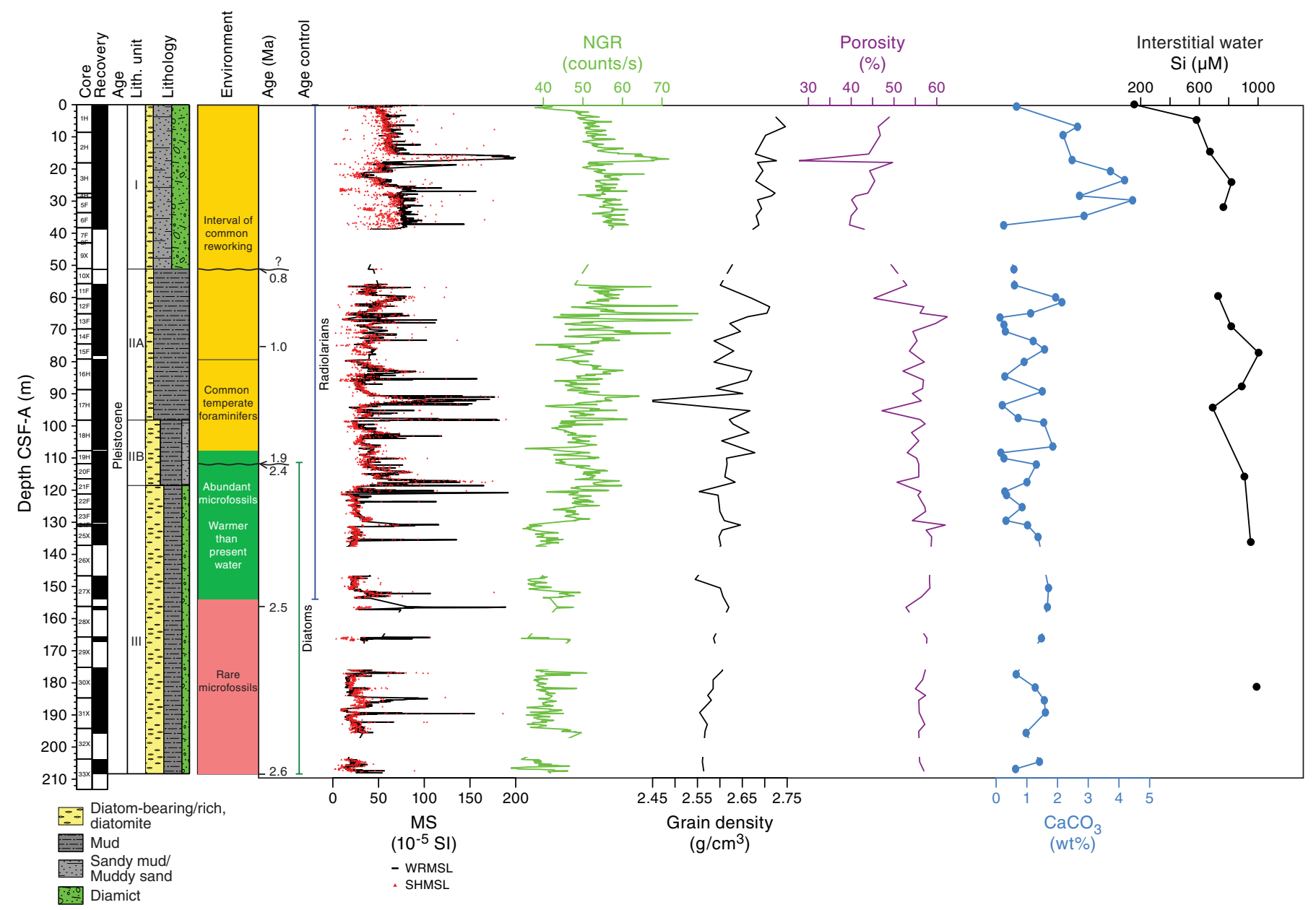

Subunit IIA also contains intervals of bioturbated foraminifer-bearing sand with sharp upper and lower contacts in the massive diatom-bearing/rich mud beds. The boundary between Subunits IIA and IIB is distinguished by the onset of very thinly laminated diatom-rich mud with better preservation and higher percentages of intact diatom frustules. Subunit IIB contains fine-grained sand and silt laminae in coarser grained diatom-rich sandy mud beds. Clasts, pyrite staining, and sand pods, lenses, and stringers are observed throughout the subunit. The base of Unit II is defined by a sharp contact between the laminated diatom-rich mud of Unit II and the underlying diatom-rich sand and diamict. Unit III consists of $\sim 90 \mathrm{~m}$ of massive to laminated greenish gray muddy diatom ooze to diatom-rich mud with dispersed to common clasts interbedded with massive bioturbated greenish gray diatom-rich sand and diamict. Clasts, pyrite staining, and coarse sand pods/lenses and stringers occur throughout.

Core catcher samples from Site U1525 were analyzed for siliceous (diatoms, radiolarians, silicoflagellates, and ebridians), calcareous (foraminifers and nannofossils), and organic (dinocysts and other aquatic palynomorphs, pollen, and spores) microfossils. Samples in the upper $\sim 107 \mathrm{~m}$ CSF-A of the interval are mostly devoid of microfossils, contain only trace numbers, or include a "residual" assemblage of resistant forms that have likely been engaged in multiple phases of transport and reworking by ice and/or bottom currents (Figure F23). Diatom taxa found in this interval were eroded and transported from discrete source beds of Miocene to early Pliocene age. One age-diagnostic radiolarian event found in this interval indicates an age older than $0.65 \mathrm{Ma}$ at $\sim 30 \mathrm{~m}$ CSF-A. Several discrete intervals of foraminifer-bearing/rich sand are present near the base of this interval, and a sparse, moderately well-preserved Neogene assemblage of calcareous nannofossils was found in one of these beds.

Deeper than $\sim 107 \mathrm{~m}$ CSF-A, siliceous microfossils are more abundant and well preserved, and several age diagnostic radiolarians and diatoms were encountered (Figure F23). Although a small background presence of reworked diatoms continues in this interval, the sequence can confidently be assigned an early Pleistocene age. Planktonic and benthic foraminifers are also most abundant and diverse in this lower Pleistocene section, and the presence of the temperate planktonic species Globoconella inflata at $\sim 89 \mathrm{~m}$ CSF-A and Globigerina bulloides and Globigerina falconensis at $\sim 125$ m CSF-A indicates the presence of warmer-than-present water. Dinocysts are sparse in this interval, and only one sample from the lower Pleistocene ( $155 \mathrm{~m}$ CSF-A) contains abundant specimens that comprise species so far only known from upper Quaternary sediments of the Atlantic sector of the Southern Ocean, south of the Polar Front.

We developed an age model for Site U1525 using a combination of radiolarian and diatom biostratigraphic events. A hiatus is detected by biostratigraphic (diatom) marker species between 111 
and $117 \mathrm{~m}$ CSF-A that constrains the age of sediments deeper than this interval to older than $2.35 \mathrm{Ma}$ and shallower sediments to younger than 1.9 Ma. The lowermost 100 m of the Site U1525 sequence represents an expanded lower Pleistocene section (Figure F23) with a sustained high sediment accumulation rate of $>60$ $\mathrm{cm} / \mathrm{ky}$. Above the disconformity, significant amounts of reworked microfossils in the upper $\sim 107 \mathrm{~m}$ preclude definitive age assignment for the interval.

Paleomagnetic investigations were primarily focused on determining the ChRM to construct a magnetostratigraphy. The initial NRM was measured at $5 \mathrm{~cm}$ intervals on most archive-half core sections, followed by NRM measurements after AF demagnetization of 10 and $20 \mathrm{mT}$ to remove a potential drilling overprint. NRM intensity of cores shallower than $\sim 100 \mathrm{~m}$ CSF-A decreases as much as an order of magnitude after $10 \mathrm{mT}$, whereas NRM intensity of cores deeper than $100 \mathrm{~m}$ CSF-A decreases by 30\%-50\% after demagnetization. Initial NRM inclination is generally steep and downward directed, but AF demagnetization removes this overprint to reveal clusters of steep upward- and downward-directed inclinations. We interpret these clusters to be normal and reversed polarity zones, respectively. To test the fidelity of these polarity zones, we also subjected a selected group of oriented discrete samples to a 20-step demagnetization protocol and used PCA to determine the ChRM direction. The discrete and archive-half measurements agree well, so we can correlate the normal and reversed polarity zones to the GPTS aided by the independent biostratigraphic age control. We identify the Jaramillo (0.988-1.072 Ma) and Cobb Mountain (1.173-1.185 Ma) Subchrons and the Olduvai Chron (1.778-1.945 Ma). We correlate a zone of reversed polarity below the hiatus to Subchron C2r.2r (2.148-2.581 Ma) based on diatom constraints.

Physical property measurements were conducted on all cores from Hole U1525A. In general, the whole-round core GRA bulk density, magnetic susceptibility, and $P$-wave velocity measurements are in good agreement with discrete MAD samples and point measurements of magnetic susceptibility and $P$-wave velocity on the section halves over the upper $131 \mathrm{~m}$, which were primarily cored with the APC and HLAPC systems (Figure F23). The switch to XCB coring deeper than $131 \mathrm{~m}$ CSF-A had an effect on whole-round measurements, especially magnetic susceptibility, NGR, and GRA bulk density, because the diameter of XCB cores does not completely fill the core liner. The $P$-wave logger was turned off deeper than 131 m CSF-A.

In lithostratigraphic Unit I, magnetic susceptibility, NGR, bulk density, $P$-wave velocity, and shear strength increase downhole and porosity decreases (Figure F23). These changes reflect both compaction and slight changes in lithology in the diatom-bearing sandy mud interbedded with clast-poor/rich muddy diamict. Peaks in magnetic susceptibility, NGR, bulk density, $P$-wave velocity, and shear strength and a decrease in porosity occur in a short interval in Unit I ( 15-18 m CSF-A), reflecting increased clasts, clay, and compaction in this diamict unit that are interpreted to be a debris flow. In Unit II, decimeter-scale cyclicity is visible in magnetic susceptibility and NGR and is likely related to downhole changes in lithology. Shear strength in Unit II also demonstrates downhole cyclicity that may be related to lithologic changes or compaction. Generally lower magnetic susceptibility, NGR, density, and $P$-wave velocity in Unit III reflect increased diatom content.

Headspace gas methane and ethane concentrations are low in the upper $124 \mathrm{~m}$ CSF-A and increase to 6640 and 7 ppmv, respectively, at $194 \mathrm{~m} \mathrm{CSF-A}$ at Site U1525. Interstitial water analyses of the mudline and 12 whole-round samples indicate biogeochemical zonation, with sulfate reduction in the uppermost $\sim 100 \mathrm{~m}$ CSF-A. Downhole variations in silicon concentration broadly correspond with lithologic changes (Figure F23), whereas calcium concentration decreases from seawater-like values in the uppermost $32 \mathrm{~m}$ CSF-A to a minimum value around the boundary between lithostratigraphic Subunit IIB and Unit III. Lithium concentration more than doubles along a linear trend deeper than $\sim 60 \mathrm{~m} \mathrm{CSF-A.} \mathrm{TOC}$ and carbonate contents are low $(<0.6 \%$ and $4.5 \%$, respectively) throughout the site. The highest and most variable carbonate content and TOC/TN ratio occur in the uppermost $34 \mathrm{~m} \mathrm{CSF-A} \mathrm{in}$ lithostratigraphic Unit I.

\section{Expedition synthesis and preliminary scientific assessment Operational considerations relating to the science objectives}

The overarching goal of Expedition 374 was to drill a transect from the outer Ross Sea continental shelf to the continental rise (Figure F24) to identify oceanic forcings and feedbacks relating to past ice sheet variability from the Neogene to Quaternary. Unfortunately, this ambition was not fully realized because a mechanical failure with the vessel resulted in termination of all drilling operations and a loss of 16 on-site operational days (from a total of 41). The loss of $39 \%$ of our operational time restricted our ability to achieve all objectives as originally envisioned. Although aspects of all objectives can be met, this unforeseen change in the operations plan severely compromised the plan to recover continuous records from the deep-water sites covering contemporaneous periods collected on the continental shelf. We also note that drilling operations in the Antarctic are inherently more challenging than other regions because of weather, ice, and lithologic considerations that have traditionally resulted in poor recovery on the Antarctic continental shelf. Expedition 374 was highly successful in this context. The discussion below provides a synthesis of these successes and highlights the importance of a flexible operations plan and large numbers of alternate sites to adapt to these Antarctic-specific considerations. We also document some of the challenges that remain despite our very targeted approach to drilling in this environment.

In general, the operations plan successfully mitigated most risks associated with weather, ice, and lithology. Recovery rates using the RCB system at the continental shelf sites were higher than expected, particularly in the lithified Miocene strata at Site U1521 (63\% total recovery), which had the highest recovery rate for ship-based drilling on the Antarctic continental shelf. Total recovery at outer continental shelf Site U1522 was 40\%, but coring proved more difficult in the unlithified Plio-Pleistocene sediments shallower than $400 \mathrm{~m}$ CSF-A (21\% recovery). However, recovery was far more successful in the upper Miocene lithified diamictite intervals deeper than $400 \mathrm{~m}$ CSF-A (64\% recovery), which were the primary targets of this site. Our original operations plan included coring at proposed Site EBOCS-04B after completing operations at Site U1522. Seismic correlations indicated that the targeted section at proposed Site EBOCS-04B is almost identical to the unlithified Plio-Pleistocene lithologies we encountered in the upper $400 \mathrm{~m}$ CSF-A at Site U1522. Given our experience of poor recovery in these lithologies at Site U1522, we had low confidence in our ability to obtain a recovery rate at proposed Site EBOCS-04B that was suitable to meet our objectives. Consequently, we modified the operations plan to core a different depositional setting at Site U1523, which targeted a Mio- 
Figure F24. Composite seismic section illustrating the transect approach from the continental shelf to the slope and rise. The seismic data have different resolutions and penetration depths because they were collected by several nations with different parameters and targets. Line BGR80-007 (24-air gun array; 23.45 L) was collected by Bundesanstalt für Geowissenschaften und Rohstoffe (Germany) in 1980, Line ATC-208 (bolt-type air gun; 35.58 L) was collected by the Institut Français du Pétrole (France) in 1982, and Lines IT94-127A ( $2 \times 20$-air gun array; 74.8 L) and IT17RS-303B (air gun; 3.44 L) were collected by Istituto Nazionale di Oceanografia e Geofisica Sperimentale (Italy) under Programma Nazionale delle Ricerche in Antartide in 1994 and 2017 , respectively.

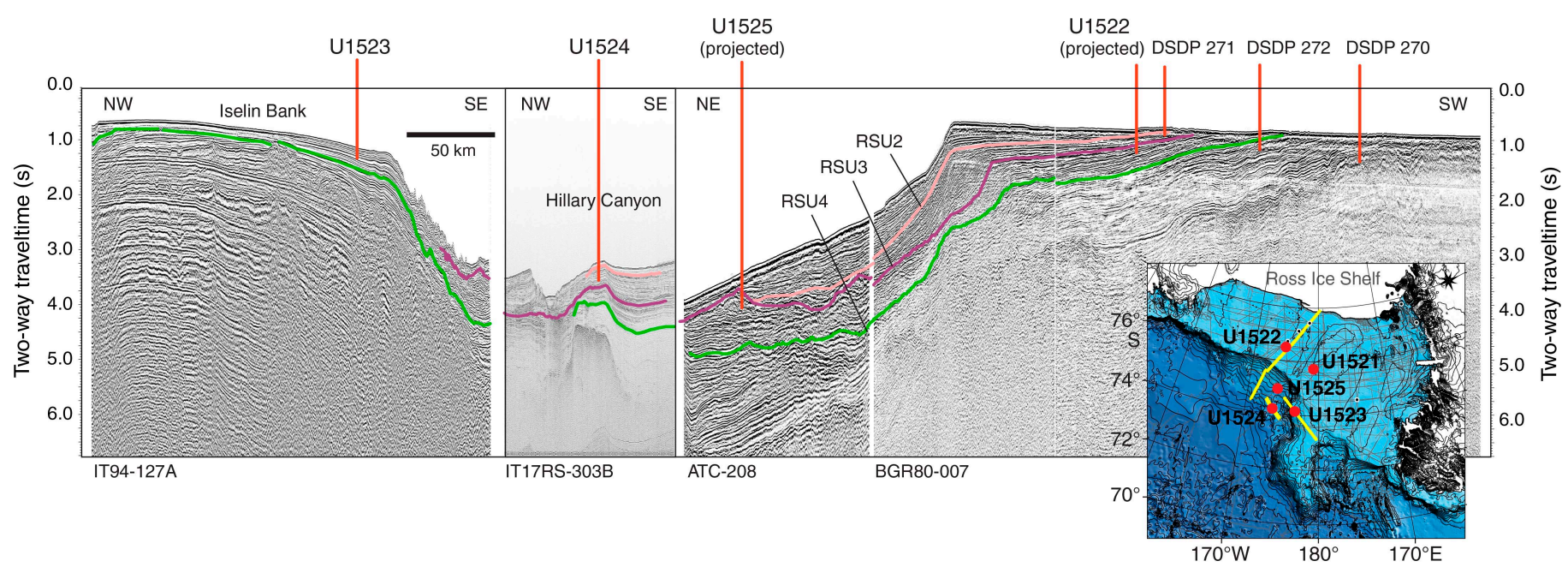

cene to Pleistocene sediment drift on the outermost continental shelf. This depositional setting had never been sampled by deep drilling in the Antarctic, although shallow piston and gravity cores indicated that the upper sediment at the site consists of unconsolidated diatom-bearing/rich mud/sandy mud with clasts. This site provided its own challenges, with soft diatom-rich muddy lithologies interbedded with unconsolidated gravels and indurated strata. Consequently, we adopted a novel approach of targeted halflength piston coring, whereby the gravel-rich and indurated lithologies that were impossible to recover with any type of coring method were identified in the first two holes (U1523A and U1523B). After examination of drilling parameters (e.g., penetration rate and weight on bit) and core catcher material and assessment of downhole logs from Hole U1523D, a final hole (U1523E) was advanced without coring through these difficult lithologies, and HLAPC cores were successfully collected in the underlying softer lithologies. This resulted in high recovery $(73 \%)$ of the targeted $\sim 95 \mathrm{~m}$ thick Plio-Pleistocene interval. XCB coring in Miocene strata below this depth was less successful, but sporadic intervals of high recovery will provide an important archive of this rarely sampled time period in Antarctica. An attempt was made to RCB core at Site U1523. As anticipated for these lithologies, recovery was very poor $(0.5 \%)$, and this hole was primarily intended to serve as a "clean" hole for downhole logging to complete the missing stratigraphy of the APC/HLAPC- and XCB-cored intervals. Thus, despite the extremely poor recovery in Hole U1523D, this RCB hole proved highly valuable because hole conditions were suitable to obtain downhole logs.

Recovery rates with the APC system were expected to be very high on the continental rise sites, and this proved to be the case. Coring at Site U1524 obtained 100\% recovery in the $270 \mathrm{~m}$ thick APC/HLAPC-cored interval. Recovery was poor in the XCB-cored interval, and many $\mathrm{XCB}$ cores returned with shattered core liners (14 out of 22;64\%). We speculated that this unexpected result was due to the very cold surface sea water $\left(-1.5^{\circ}\right.$ to $\left.-2^{\circ} \mathrm{C}\right)$ used as drilling fluid. This issue should be investigated for future expeditions that drill in extreme cold-water regions. At Site U1524, XCB coring was terminated because of poor recovery. This decision coincided with a weather event that pushed sea ice toward the site. We mitigated for sea ice risk in our plan by identifying several alternate sites. The shipboard ice observer indicated that the sea ice would pass completely over Site U1524 in $\sim 3$ days. Considering the short time window for operations elsewhere before we could return to Site U1524 to complete our primary objectives, we collected a single APC core in Hole U1524B for high-resolution microbiological and interstitial water sampling. We then temporarily abandoned Site U1524 and decided to piston core nearby $(47 \mathrm{nmi})$ continental slope Site U1525. This site required minimal transit time and provided a complementary record that overlaps the upper part of Site U1524 but in a more proximal setting to the continental shelf, thus providing a hybrid record of the depositional processes observed at Sites U1523 and U1524 (e.g., ASC vigor and AABW formation, respectively). After being informed that the sea ice would drift off Site U1524 by the next day, we terminated coring at $213.2 \mathrm{~m}$ DSF because the XCB coring at Site U1525 also proved problematic (multiple shattered core liners). We returned to Site U1524 to core with the RCB system to a target depth of $1000 \mathrm{~m}$ CSF-A, but the site was terminated at $442 \mathrm{~m}$ DSF because of the mechanical failure and termination of all drilling operations. Consequently, Site U1524 was terminated before our stratigraphic target could fully be met, and we were unable to obtain the deeper sediment that was a primary objective of the site. This deeper sediment would have contained a middle Miocene continental rise record of paleoenvironments from the same time period as the high-quality continental shelf record from Site U1521. Termination of operations also precluded us from coring a final hole to APC refusal to recover a complete stratigraphy in the upper part of the sequence. Despite these setbacks, many aspects of the continental shelf-to-rise transect can be achieved for the Plio-Pleistocene interval through comparison with records from Sites U1522U1525 and the ANDRILL program.

The mechanical failure also meant we could not recover a record from proposed Site RSCR-19A, which was a late-addition alternate site that was upgraded to a primary site during the early phase of the expedition because we recognized it was the most suit- 
able site at which to obtain a high-fidelity, continuous record of pelagic/hemipelagic sedimentation in the Ross Sea. Despite the unforeseen mechanical issue compromising much of the science plan, the material recovered during Expedition 374 will still provide unprecedented insights into the coupled nature of past marinebased ice sheets in West Antarctica and the adjacent water masses directly offshore. Our operational plan and risk mitigation strategy were successful, as was recovery of upper Miocene and older strata on the Ross Sea continental shelf using rotary coring methods. APC coring methods also demonstrated that high-quality, continuous drill core records can be obtained from the Antarctic continental slope and rise.

\section{Preliminary scientific assessment}

Our drilling plan identified a series of sites where a source-tosink sedimentary system could be mapped through the extensive network of Ross Sea seismic surveys. It targeted a continental shelfto-rise transect approach (Figure F24) that would allow for a detailed assessment of oceanic-ice sheet interactions back to at least the late early Miocene (Figure F3). Critically, we located the drill sites on the outer Ross Sea continental shelf because models indicate that this sector of the Antarctic is the most sensitive to oceanic heat flux during deglacial events and, conversely, is one of the last areas of the continental shelf to become glaciated during past glacial advance events (Figure F4). Thus, the records from the sites provide an end-member scenario for identifying the climatic thresholds required to achieve a fully glaciated state in Antarctica, as well as identifying oceanic triggers for glacial retreat. Sites U1521 and U1522 were drilled on the outer Ross Sea continental shelf (Figure F2) and explicitly designed to directly identify the timing of past grounding and retreat events of marine-based ice sheets in the Ross Sea. Site U1521 targeted a middle Miocene record to identify the processes that lead to the expansion of large ice streams emanating from the EAIS across the western Ross Sea continental shelf and to recover a semicontinuous record of the MCO in a relatively iceproximal location.

We cored a $650 \mathrm{~m}$ thick sequence of interbedded diamictite and diatom-rich mudstone strata at Site U1521 (Figure F11, F25), with the aim of sampling above and below RSU4. The depositional reconstructions obtained from these lithologies will provide unprecedented insight into environmental change at the Antarctic margin during the middle Miocene. Site U1522 targeted a Pleistocene to upper Miocene sequence from the outer shelf (Figure F14, F25) with the primary objective to penetrate and date RSU3, which is interpreted to represent the first major continental shelf-wide expansion and coalescing of marine-based ice streams from both East and West Antarctica. Recovery at Site U1522 was in line with expectations, and the primary objective of dating RSU3 was achieved. The lithology at Site U1522 is dominated by diamictite, and lithologic variations are subtler than those at Site U1521. Thin diatom-rich mudstone and diatomite beds were recovered in some intervals, and they will provide snapshot records of a deglaciated outer shelf environment in the late Miocene. Finer grained (diatomite to diatomrich mud) and unconsolidated diamict and gravel-rich beds indicated by the FMS log were likely present but were possibly washed away in the coring process at Sites U1521 and U1522. However, downhole logging operations were successful at both sites and allow for a fuller assessment of lithologic cyclicity. Outer continental shelf Site U1523 is a sediment drift that yielded a sequence of diatom ooze, foraminifer-rich sand, gravel, and diamict and enables the reconstruction of a record of changing surface and intermediate water properties (e.g., SST, salinity, and nutrient availability) and productivity at this location near the continental shelf break. Furthermore, the location of Site U1523 beneath the westward flowing ASC (Figure F5) will allow reconstruction of the changing vigor of this current through time. This reconstruction will enable testing of the hypothesis that changes in ASC vigor regulate heat flux onto the continental shelf, thus making the ASC a key control on ice sheet mass balance.

At Site U1524, we cored a sedimentary sequence on the continental rise on the levee of the Hillary Canyon (Figure F24), one of the largest conduits of AABW delivery from the Antarctic continental shelf into the abyssal ocean. We were mostly successful in achieving our objectives at this site by recovering a high-quality Plio-Pleistocene record (Figure F20, F25) of turbidite activity relating to transport of cascading water masses (e.g., AABW) down the Hillary Canyon. This record can provide a reconstruction of this critical component of the global oceanic overturning circulation. Recovered overspill turbidite deposits are interbedded with periods of pelagic deposition and will enable proxy reconstructions of surface and bottom water properties. However, Site U1524 was intended to provide a record that extends to the middle Miocene to overlap with the continental record obtained at Site U1521. This objective was not achieved as originally planned because of the mechanical failure that ended operations. In principle, the PlioPleistocene AABW record collected at Site U1524 can be correlated to the ice sheet variability record at Site U1522, but poor recovery in the Plio-Pleistocene interval of Site U1522 will make such correlations challenging. However, previous drilling at ANDRILL Site AND-1B recovered an exceptional record of inner continental shelf ice sheet variance through this time interval (Naish et al., 2009). Correlation to that site will allow for an unprecedented link between continental shelf processes and changing AABW flux into the deep ocean through this time period. In addition, links to changing surface water properties and ASC vigor can be made through correlations to Site U1523.

At Site U1525, we also cored a continental slope levee system near the flank of the Hillary Canyon (Figure F22), but the upper $\sim 50$ $\mathrm{m}$ of the system was buried by the margin of a large trough-mouth fan deposit west of the site. The site is closer to the continental shelf break and consequently is more influenced by the ASC than Site U1524. The lithofacies suggest an increased influence of traction currents relating to this current together with a higher IRD content (Figure F23). Thus, this site may provide an important and unique hybrid record of AABW formation, ASC current vigor, and iceberg discharge relating to dynamic ice sheet processes on the continental shelf and/or along the Pacific margin of the WAIS. The Site U1525 core record overlaps in time with the records obtained at Sites U1523 and U1524 (Figure F25) and ANDRILL Site AND-1B (Naish et al., 2001; McKay et al., 2009). 
Figure F25. Chronostratigraphy of Expedition 374 sites showing preliminary age constraints and locations of major lithologic boundaries and unconformities. Core numbers are at the right of each column, and ages in millions of years are at the left.

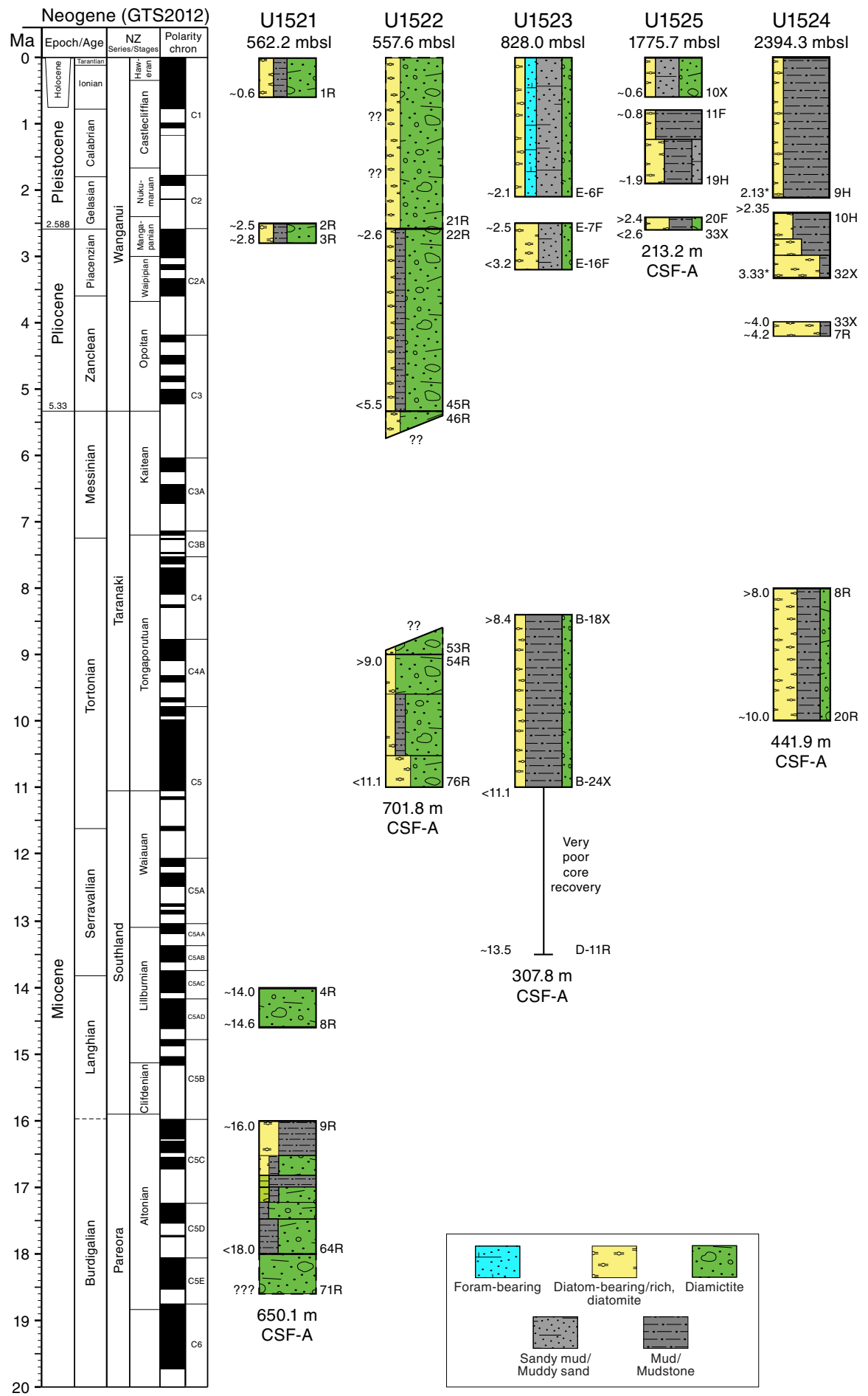

\section{Science objectives achieved during Expedition 374}

The discussion above provides an overview of the difficulties in achieving all of the expedition objectives caused by the mechanical failure of the vessel and early return to port. Critically, we lost the ability to develop stratigraphic ties between the continental shelf and the deep ocean during the Miocene time period. This was a fundamental component of our science plan, which sought a continental shelf-to-rise transect to understand ocean-ice sheet interactions during the warmer-than-present Neogene, with a particular focus on the MCO ( 17-14.5 Ma), mid-Pliocene ( 4-3 Ma), and Pleistocene superinterglacials. The successes relating to the science objectives, noting this caveat and that key aspects of most objectives were not achieved as originally intended, are discussed below. 


\section{Evaluate the contribution of West Antarctica to far- field ice volume and sea level estimates}

RSU4 and RSU3 were penetrated at Sites U1521 and U1522, respectively, during Expedition 374 (Figure F6), and their ages will be refined during postcruise analysis. The ages of these unconformities were previously poorly constrained, and improved estimates of these ages (Figure F6) will constrain the timing of the first large expansion of the marine-based ice sheets sourced from the EAIS into the western and central Ross Sea (RSU4) and the first marine-based WAIS advances to the continental shelf edge (RSU3). Models indicate that grounded ice sheets on the outermost continental shelf in the Ross Sea imply a maximum ice sheet extent on the Antarctic continent as a whole (Pollard and DeConto 2009; Golledge et al 2013). Therefore, integration with the ice sheet retreat events from the ANDRILL records (Sites AND-1B and AND-2A) will allow for assessment of the WAIS contribution to Neogene sea level estimates. Lithofacies analyses at continental shelf Sites U1521 and U1522 combined with seismic stratigraphic correlations will identify deposition during periods of grounded-ice, glaciomarine, and open-marine conditions. Sediment provenance studies at Sites U1521 and U1522 will enable understanding of the changes in the source region of sediments and identify whether glacial transport and deposition is sourced from local ice caps or large-scale ice sheet expansion (e.g., East versus West Antarctic source).

\section{Reconstruct ice-proximal atmospheric and oceanic temperatures to identify past polar amplification and assess its forcings/feedbacks}

All of the records obtained during Expedition 374 are relevant to addressing this objective, and most sites contain lithofacies suitable for proxy-based reconstruction of past climatic and oceanographic conditions at the Antarctic margin during warmer-thanpresent climates. Diatom-rich mud and diatom ooze (diatomite) are present in discrete intervals at all sites (Figure F25), and initial microfossil analyses demonstrate the possibility for high-resolution diatom, radiolarian, and palynological studies (Figures F26, F27) to reconstruct past variations in SSTs, surface water stratification (related to meltwater input and sea ice formation), and biological productivity. Calcareous foraminifers occur sporadically but are more abundant in some Pliocene and Pleistocene interglacial sequences at Sites U1523 and U1525 (Figures F17, F23). Biogenic carbonate, including foraminifers, is more common in middle Miocene sequences and in a diatom-rich mud interval at Site U1521 (Figure F11). The latter contains abundant articulated bivalves that provide opportunities for stable isotope, trace element, and clumped isotope analyses. The application of additional proxies for past temperature reconstructions, including biomarker proxies (e.g., TEX86), will be investigated at all sites. Pollen-based reconstructions and terrestrial biomarker proxies (e.g., MBT/CBT) will allow us to determine the extent of atmospheric polar amplification during these time periods and to track the resulting terrestrial runoff during the warmer climates of the Pliocene and Miocene.

\section{Assess the role of oceanic forcing on WAIS stability/instability}

ANDRILL Sites AND-1B and AND-2A provided compelling evidence of a smaller-than-present WAIS during the MCO, the warm Pliocene, and the early Pleistocene climates, which was likely a consequence of wind-driven upwelling of warm water onto the conti- nental shelf (Naish et al., 2009; Pollard and DeConto, 2009; Levy et al., 2016). Expedition 374 aimed to test this hypothesis by obtaining new records of ice sheet extent from continental shelf Sites U1521 and U1522 to complement and expand on the ANDRILL record and provide a record of changing ocean current vigor and water masses near the continental shelf break (Site U1523), continental slope (Site U1525), and continental rise (Site U1524). At the sites most proximal to the continental shelf break (Sites U1523 and U1525), paleocurrent strength associated with changes in the westwardflowing ASC will be reconstructed by examining the sedimentological (e.g., facies analysis and grain size) characteristics and magnetic fabrics.

Micropaleontological, geochemical, and sedimentological studies from Expedition 374 cores will provide reconstructions of changing regional surface conditions that are relevant to water mass exchange between the Southern Ocean and the Ross Sea continental shelf/WAIS (e.g., sea ice, surface stratification, SSTs, polynya mixing, glacial meltwater discharge, nutrient uptake, and supercooling of dense water by ice shelves). Downslope currents resulting from the transfer of RSBW into the abyssal ocean (e.g., AABW formation) can also be assessed (and distinguished from ASC flow) by integrated bio- and lithofacies analyses, geochemistry, and micropaleontology at Sites U1523-U1525. Foraminifer-bearing/rich beds occur in several intervals at both Sites U1523 and U1525 and hold promise for stable isotope and trace element analysis to reconstruct past water mass and temperature variations at these sites.

\section{Identify the sensitivity of WAIS to Earth's orbital configuration under a variety of climate boundary conditions}

Fundamental questions remain about the orbital pacing of AIS variability. In particular, records obtained during Expedition 374 should shed light on whether orbitally paced AIS variations responded to local insolation forcing or were regulated by interhemispheric teleconnections associated with low-latitude or highnorthern latitude drivers. Sedimentological analyses (complemented by downhole logs) will enable development of a direct record of orbital-scale ice sheet advances and retreats across the continental shelf at Sites U1521 and U1522. The turbidite levee deposits at continental rise and slope Sites U1524 and U1525 are believed to be the consequence of water masses cascading down the Hillary Canyon (Figure F5). As such, these deposits are anticipated to provide a record of changes in AABW production and delivery of sediment to the continental shelf by ice sheet advances through time. These records can then be directly related to changing ice sheet and sea ice extent on the Ross Sea continental shelf and tied to far-field sea-level, temperature, and water mass records. Superimposed on this AABW signal will be an orbital-scale record of IRD and ASC vigor that will link changes in AABW production and export to shifting ice dynamics along the Pacific Ocean margin of the WAIS.

\section{Reconstruct eastern Ross Sea bathymetry to examine relationships between seafloor geometry, ice sheet stability/instability, and global climate}

The modern-day bathymetry of the Ross Sea is characterized by an overdeepened continental shelf that makes the WAIS vulnerable to marine ice sheet instability. With this bathymetric configuration, once a climatic warming triggers an ice sheet retreat event, the grounding line retreats into increasingly deeper water, resulting in 
Figure F26. Microfossils from Ross Sea sediments, Expedition 374. Specimen sizes $=\sim 20-200 \mu \mathrm{m}$. Diatoms: A. Thalassiosira vulnifica (U1523B-10F-CC). B. Actinocyclus karstenii (U1523B-10F-CC). C. Actinocyclus sp. B of Harwood and Maruyama (1992) (U1523E-16F-CC). D. Actinocyclus maccollumii (U1523E-10FCC). Radiolarians: E. Actinommidid radiolarian (Hole U1523A mudline). F. Spongodiscidid radiolarian fragment (Hole U1523A mudline). G. Spongoplegma (?) spp. (Hole U1523A mudline). H. Spongopyle spp. (Hole U1523A mudline). Foraminifers: I. Cibicidoides grossepunctatus (U1523B-11F-CC). J. Globocassidulina biora, pustulose form (U1522A-2R-CC). K. Globoconella inflata (U1525A-16H-CC). L. Nonionella iridea (U1521A-21R-CC). Dinoflagellates: M. Selenopemphix sp. 1 (U1525A-27X-CC). N. Selenopemphix bothrion (U1523B-20F-CC). O. Lejeunecista sp. cf. Lejeunecista communis (U1523B-22F-CC). P. Operculodinium? eirikianum (U1521A-16R-CC).

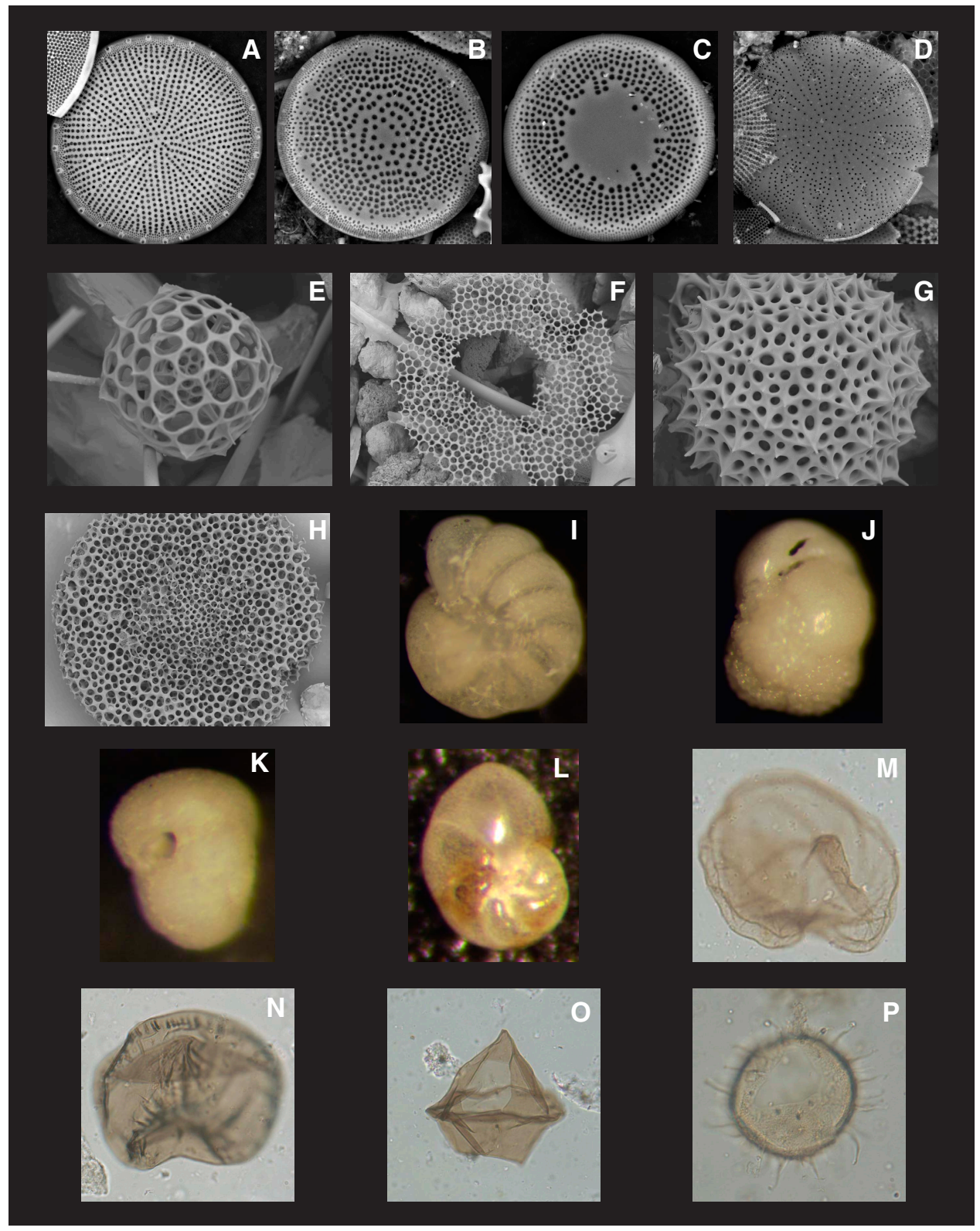

increased flux of ice discharging into the ocean (and melting) (Weertman, 1974; Thomas and Bentley, 1978, Colleoni et al., 2018b). This increased flux leads to a runaway retreat process, even if there is no further climate forcing. Consequently, the transition from a terrestrial- or shallow marine-based West Antarctica with a seaward-dipping shallow continental shelf to that of the modern overdeepened (i.e., landward dipping) continental shelf has a firstorder control on the sensitivity of the AIS to external climate and oceanic boundary conditions (Wilson et al., 2013; Gasson et al., 2016, Colleoni et al., 2018a; 2018b). The timing of Ross Sea shelf overdeepening is poorly constrained, and the location of Expedition
374 sites was selected to help improve the age constraints on the key seismic unconformities relating to this event. The sites should also provide important reconstructions of the depositional environment (e.g., water depth) relevant to the paleobathymetry at the time of formation of RSU4, RSU3, and RSU2 (Figure F6) at Sites U1521 and U1522. These three unconformities document fundamental shifts in the eastern Ross Sea that relate to erosion by advancing ice streams across a relatively shallow continental shelf from East Antarctica (RSU4), West Antarctica (RSU3), and the transition toward an overdeepened continental shelf by RSU2 time. All three of these 
Figure F27. Diatom specimens from Ross Sea sediments, Expedition 374. A-F. Actinocyclus karstenii. (A, D: U1523E-10F-CC; B-E and F [interior view]: U1523B10F-CC). G. Actinocyclus sp. B of Harwood and Maruyama (1992) (U1523E-16F-CC). H. Stellarima microtrias (U1523B-10F-CC). I-K. Actinocyclus maccollumii (U1523E-10F-CC; I [interior view]). L. Thalassiosira striata (U1523E-16F-CC). M, N. Thalassiosira vulnifica, M with corroded valve (U1523E-10F-CC). O. Thalassiosira webbi (U1523B-10F-CC). P. Thalassiosira kolbei U1523B-10F-CC). Q, R (internal view), S, T. Thalassiosira torokina (Q, R: U1523E-10F-CC; S, T: U1523E-16F-CC).

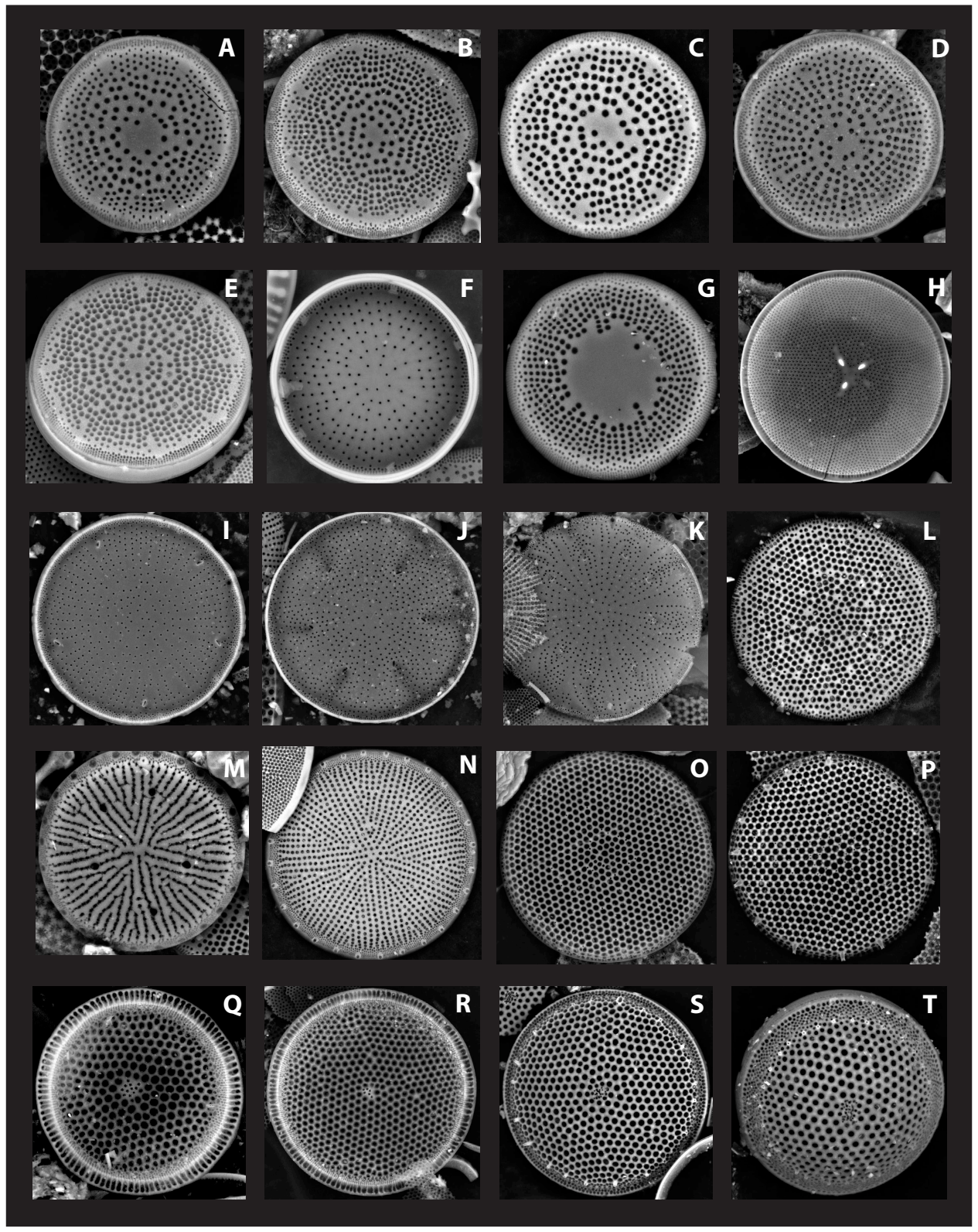

unconformities were penetrated on the continental shelf during Expedition 374, which greatly reduces the uncertainty in their ages.

\section{Additional expedition contributions}

Numerous campaigns to drill the Antarctic margin have been conducted over the past five decades. Despite these efforts, the margin still remains understudied with respect to the deep biosphere and hydrological system. To address this shortcoming, dedicated mudline APC cores were collected at Sites U1523 and U1524 for high-resolution microbiological and interstitial water sampling. These cores will enable the first characterization of the vertical distribution of microbial flora in the deep biosphere of the Ross Sea.
Metagenomics analyses of high-resolution subsamples will provide further information on the biodiversity of bacteria, methanogens, and fungi in an understudied polar area. Additionally, metabolism and activities of deep-biosphere communities will be characterized using biogeochemical and molecular studies. The combination of interstitial water chemistry and sediment samples can elucidate biogeochemical cycling of elements and isotopes. Being able to conduct such studies at high resolution in the uppermost part of the sediment column is unprecedented for the Ross Sea shelf and rise and will provide unique insights into microbiology, early diagenetic processes, and redox profiles. 


\section{References}

Ainley, D.G., and Jacobs, S.S., 1981. Sea-bird affinities for ocean and ice boundaries in the Antarctic. Deep Sea Research, Part A: Oceanographic Research Papers, 28(10):1173-1185. https://doi.org/10.1016/0198-0149(81)90054-6

Alonso, B., Anderson, J.B., Diaz, J.I., and Bartek, L.R., 1992. Pliocene-Pleistocene seismic stratigraphy of the Ross Sea: evidence for multiple ice sheet grounding episodes. In Elliot, D.H. (Ed.), Antarctic Research Series (Volume 57): Contributions to Antarctic Research III: Washington DC (American Geophysical Union), 93-103. https://agupubs.onlinelibrary.wiley.com/doi/10.1029/AR057p0093

Anderson, J.B., 1999. Antarctic Marine Geology: Cambridge, United Kingdom (Cambridge University Press). https://doi.org/10.1017/CBO9780511759376

Anderson, J.B., and Bartek, L.R., 1992. Cenozoic glacial history of the Ross Sea revealed by intermediate resolution seismic reflection data combined with drill site information. In Kennett J.P., and Warnke D. (Eds.), Antarctic Research Series (Volume 56): The Antarctic Paleoenvironment: A Perspective on Global Change: Part One: Washington DC (American Geophysical Union), 231-263. https://agupubs.onlineli-

brary.wiley.com/doi/pdf/10.1029/AR056p0231

Anderson, J.B., Simkins, L.M., Bart, P.J., De Santis, L., Halberstadt, A.R.W., Olivo, E., and Greenwood, S.L., 2018. Seismic and geomorphic records of Antarctic Ice Sheet evolution in the Ross Sea and controlling factors in its behaviour. In Le Heron, D. P., Hogan, K. A., Phillips, E. R., Huuse, M., Busfield, M.E., and Graham, A.G.C. (Eds), Glaciated Margins: The Sedimentary and Geophysical Archive. Geological Society Special Publication, 475. https://doi.org/10.1144/SP475.5

Arndt, J.E., Schenke, H.W., Jakobsson, M., Nitsche, F.-O., Buys, G., Goleby, B., Rebesco, M., et al., 2013a. The International Bathymetric Chart of the Southern Ocean (IBCSO)-digital chart for printing. PANGAEA. https://doi.org/10.1594/PANGAEA.805735

Arndt, J.E., Schenke, H.W., Jakobsson, M., Nitsche, F.-O., Buys, G., Goleby, B., Rebesco, M., et al., 2013b. The International Bathymetric Chart of the Southern Ocean (IBCSO) Version 1.0-a new bathymetric compilation covering circum-Antarctic waters. Geophysical Research Letters, 40(12):3111-3117. https://doi.org/10.1002/grl.50413

Barrett, P.J., 1975. Textural characteristics of Cenozoic preglacial and glacial sediments at site 270, Ross Sea, Antarctica. In Hayes, D.E., Frakes, L.A., et al., Initial Reports of the Deep Sea Drilling Project, 28. Washington, DC (U.S Government Printing Office), 757-767. https://doi.org/10.2973/dsdp.proc.28.122.1975

Barrett, P.J., 1981. History of the Ross Sea region during the deposition of the Beacon Supergroup 400-180 million years ago. Journal of the Royal Society of New Zealand, 11(4):447-458. https://doi.org/10.1080/03036758.1981.10423334

Barrett, P.J., 1989. Antarctic Cenozoic history from the CIROS-1 drillhole, McMurdo Sound. DRIS Bulletin, 245.

Barrett, P.J., 2007. Cenozoic climate and sea level history from glaciomarine strata off the Victoria Land coast, Cape Roberts Project, Antarctica. In Hambrey, M.J., Christoffersen, P., Glasser, N.F., and Hubbard, B. (Eds.), Glacial Sedimentary Processes and Products. Special Publication of the International Association of Sedimentologists, 39:259-288.

Bart, P.J., 2003. Were West Antarctic Ice Sheet grounding events in the Ross Sea a consequence of East Antarctic Ice Sheet expansion during the middle Miocene? Earth and Planetary Science Letters, 216(1-2):93-107. https://doi.org/10.1016/S0012-821X(03)00509-0

Bart, P.J., De Batist, M., and Jokat, W., 1999. Interglacial collapse of Crary Trough-mouth fan, Weddell Sea, Antarctica: implications for Antarctic glacial history. Journal of Sedimentary Research, 69(6):1276-1289. https://doi.org/10.2110/jsr.69.1276

Bart, P.J., and De Santis, L., 2012. Glacial intensification during the Neogene: a review of seismic stratigraphic evidence from the Ross Sea, Antarctica, continental shelf. Oceanography, 25(3):166-183.

https://doi.org/10.5670/oceanog.2012.92
Bart, P.J., and Iwai, M., 2012. The overdeepening hyphothesis: how erosional modification of the marine-scape during the early Pliocene altered glacial dynamics on the Antarctic Peninsula's Pacific margin. Palaeogeography, Palaeoclimatology, Palaeoecology, 335-336:42-51. https://doi.org/10.1016/j.palaeo.2011.06.010

Bart, P.J., Sjunneskog, C., and Chow, J.M., 2011. Piston-core based biostratigraphic constraints on Pleistocene oscillations of the West Antarctic Ice Sheet in western Ross Sea between North Basin and AND-1B drill site. Marine Geology, 289(1-4):86-99. https://doi.org/10.1016/j.margeo.2011.09.005

Bart, P.J., DeCesare, M., Rosenheim, B.E., Majewski, W., and McGlannan, A., 2018. A centuries-long delay between a paleo-ice-shelf collapse and grounding-line retreat in the Whales Deep Basin, eastern Ross Sea, Antarctica. Scientific Reports, 8: 2392. https://doi.org/10.1038/s41598-018-29911-8

Behrendt, J.C., LeMasurier, W.E., Cooper, A.K., Tessensohn, F., Tréhu, A., and Damaske, D., 1991. Geophysical studies of the West Antarctic rift system. Tectonics, 10(6):1257-1273. https://doi.org/10.1029/91TC00868

Bergamasco, A., Defendi, V., Zambianchi, E., and Spezie, G., 2002. Evidence of dense water overflow on the Ross Sea shelf-break. Antarctic Science, 14(3):271-277. https://doi.org/10.1017/S0954102002000068

Bianchi, G.G., Hall, I.R., McCave, I.N., and Joseph, L., 1999. Measurement of the sortable silt current speed proxy using the Sedigraph 5100 and Coulter Multisizer IIe: precision and accuracy. Sedimentology, 46(6):1001-1014. https://doi.org/10.1046/j.1365-3091.1999.00256.x

Böhm, G., Ocakoğlu, N., Picotti, S., and De Santis, L., 2009. West Antarctic Ice Sheet evolution: new insights from a seismic tomographic 3D depth model in the Eastern Ross Sea (Antarctica). Marine Geology, 266(14):109-128. https://doi.org/10.1016/j.margeo.2009.07.016

Brancolini, G., Busetti, M., Marchetti, M., De Santis, L., Zanolla, C., Cooper, A.K., Cochrane, G.R., et al., 1995. Seismic stratigraphic atlas of the Ross Sea, Antarctica. In Cooper, A.K., Barker, P.F., and Brancolini, G. (Eds.), Antarctic Research Series (Volume 68): Geology and Seismic Stratigraphy of the Antarctic Margin: Washington, DC (American Geophysical Union), A271-A286.

Caburlotto, A., Lucchi, R.G., De Santis, L., Macrì, P., and Tolotti, R., 2010. Sedimentary processes on the Wilkes Land continental rise reflect changes in glacial dynamic and bottom water flow. International Journal of Earth Sciences, 99(4):909-926. https://doi.org/10.1007/s00531-009-0422-8

Chow, J.M., and Bart, P.J., 2003. West Antarctic Ice Sheet grounding events on the Ross Sea outer continental shelf during the middle Miocene. Palaeogeography, Palaeoclimatology, Palaeoecology, 198(1-2):169-186. https://doi.org/10.1016/S0031-0182(03)00400-0

Cody, R., Levy, R., Crampton, J., Naish, T., Wilson, G., and Harwood, D., 2012. Selection and stability of quantitative stratigraphic age models: PlioPleistocene glaciomarine sediments in the ANDRILL 1B drillcore, McMurdo Ice Shelf. Global and Planetary Change, 96-97:143-156. https://doi.org/10.1016/j.gloplacha.2012.05.017

Cody, R.D., Levy, R.H., Harwood, D.M., and Sadler, P.M., 2008. Thinking outside the zone: high-resolution quantitative diatom biochronology for the Antarctic Neogene. Palaeogeography, Palaeoclimatology, Palaeoecology, 260(1-2):92-121. https://doi.org/10.1016/j.palaeo.2007.08.020

Cook, C.P., van de Flierdt, T., Williams, T., Hemming, S.R., Iwai, M., Kobayashi, M., Jimenez-Espejo, F.J., et al., 2013. Dynamic behaviour of the East Antarctic Ice Sheet during Pliocene warmth. Nature Geoscience, 6(9):765-769. https://doi.org/10.1038/ngeo1889

Colleoni, F., De Santis, L., Montoli, E., Olivo, E., Sorlien, C.C., Bart, P.J., Gasson, E.G.W., et al., 2018a. Past continental shelf evolution increased Antarctic Ice Sheet sensitivity to climatic conditions. Scientific Reports, 8(1):11323. https://doi.org/10.1038/s41598-018-29718-7

Colleoni, F., De Santis, L., Siddoway, C.S., Bergamasco, A., Golledge, N.R., Lohmann, G., Passchier, S., and Siegert, M.J., 2018b. Spatio-temporal variability of processes across Antarctic ice-bed-ocean interfaces. Nature Communications, 9(1):2289.

https://doi.org/10.1038/s41467-018-04583-0

Cooper, A.K., Barker, P.F., and Brancolini, G. (Eds.), 1997. Antarctic Research Series (Volume 68): Geology and Seismic Stratigraphy of the Antarctic 
Margin: Washington, DC (American Geophysical Union). https://doi.org/10.1029/AR068

Cooper, A.K., Barrett, P.J., Hinz, K., Traube, V., Leitchenkov, G., and Stagg, H.M.J., 1991. Cenozoic prograding sequences of the Antarctic continental margin: a record of glacio-eustatic and tectonic events. Marine Geology, 102(1-4):175-213. https://doi.org/10.1016/0025-3227(91)90008-R

Cooper, A.K., and O'Brien, P.E., 2004. Leg 188 synthesis: transitions in the glacial history of the Prydz Bay region, East Antarctica, from ODP drilling. In Cooper, A.K., O'Brien, P.E., and Richter, C. (Eds.), Proceedings of the Ocean Drilling Program, Scientific Results, 188: College Station, TX (Ocean Drilling Program), 1-42. https://doi.org/10.2973/odp.proc.sr.188.001.2004

Cramer, B.S., Toggweiler, J.R., Wright, J.D., Katz, M.E., and Miller, K.G., 2009. Ocean overturning since the Late Cretaceous: inferences from a new benthic foraminiferal isotope compilation. Paleoceanography, 24(4). https://doi.org/10.1029/2008PA001683

Crampton, J.S., Cody, R.D., Levy, R., Harwood, D., McKay, R., and Naish, T.R., 2016. Southern Ocean phytoplankton turnover in response to stepwise Antarctic cooling over the past 15 million years. Proceedings of the National Academy of Sciences, 113(25):6868-6873. https://doi.org/10.1073/pnas.1600318113

Dahl-Jensen, D., Albert, M.R., Aldahan, A., et al., 2013. Eemian interglacial reconstructed from a Greenland folded ice core. Nature, 493(7433):489_ 494. https://doi.org/10.1038/nature11789

De Santis, L., Anderson, J.B., Brancolini, G., and Zayatz, I., 1995. Seismic record of late Oligocene through Miocene glaciation on the Central and Eastern Continental Shelf of the Ross Sea. In Cooper, A.K., Barker, P.F., and Brancolini, G. (Eds.), Antarctic Research Series (Volume 68): Geology and Seismic Stratigraphy of the Antarctic Margin: Washington, DC (American Geophysical Union), 235-260. https://doi.org/10.1029/AR068p0235

De Santis, L., Anderson, J.B., Brancolini, G., and Zayatz, I., 1997. Glaciomarine deposits on the continental shelf of Ross Sea, Antarctica. In Davies, T.A., Bell, T., Cooper, A.K., Josenhans, H., Polyak, L., Solheim, A., Stoker, M.S., and Stravers, J.A. (Eds.), Glaciated Continental Margins: An Atlas of Acoustic Images: London (Chapman \& Hall), 110-113. https://doi.org/10.1007/978-94-011-5820-6_41

De Santis, L., Prato, S., Brancolini, G., Lovo, M., and Torelli, L., 1999. The eastern Ross Sea continental shelf during the Cenozoic: implications for the West Antarctic ice sheet development. Global and Planetary Change, 23(1-4):173-196. https://doi.org/10.1016/S0921-8181(99)00056-9

Decesari, R.C., Sorlien, C.C., Luyendyk, B.P., Wilson, D.S., Bartek, L., Diebold, J., and Hopkins, S.E., 2007. Regional seismic stratigraphic correlations of the Ross Sea: implications for the tectonic history of the West Antarctic rift system. In Cooper, A.K., Raymond, C.R., et al. (Eds.), Antarctica: A Keystone in a Changing World-Online Proceedings of the 10th ISAES. USGS Open File Report 2007-1047, Short Research Paper 052. https://doi.org/10.3133/of2007-1047.srp052

DeConto, R.M., and Pollard, D., 2016. Contribution of Antarctica to past and future sea-level rise. Nature, 531(7596):591-597. https://doi.org/10.1038/nature17145

Elderfield, H., Ferretti, P., Greaves, M., Crowhurst, S., McCave, I.N., Hodell, D., and Piotrowski, A.M., 2012. Evolution of ocean temperature and ice volume through the mid-Pleistocene Climate Transition. Science, 337(6095):704-709. https://doi.org/10.1126/science.1221294

Expedition 318 Scientists, 2011. Expedition 318 summary. In Escutia, C., Brinkhuis, H., Klaus, A., and the Expedition 318 Scientists, Proceedings of the Integrated Ocean Drilling Program, 318: Tokyo (Integrated Ocean Drilling Program Management International, Inc.). https://doi.org/10.2204/iodp.proc.318.101.2011

Feakins, S.J., Warny, S., and Lee, J.-E., 2012. Hydrologic cycling over Antarctica during the middle Miocene warming. Nature Geoscience, 5(8):557560. https://doi.org/10.1038/ngeo1498

Fielding, C.R., Browne, G.H., Field, B., Florindo, F., Harwood, D.M., Krissek, L.A., Levy, R.H., Panter, K.S., Passchier, S., and Pekar, S.F., 2011. Sequence stratigraphy of the ANDRILL AND-2A drillcore, Antarctica: a long-term, ice-proximal record of early to mid-Miocene climate, sea-level and glacial dynamism. Palaeogeography, Palaeoclimatology, Palaeoecology, 305(14):337-351. https://doi.org/10.1016/j.palaeo.2011.03.026

Fielding, C.R., Naish, T.R., Woolfe, K.J., and Lavelle, M.A., 2000. Facies analysis and sequence stratigraphy of CRP-2/2A, Victoria Land Basin, Antarctica. Terra Antartica, 7(3):323-338.

https://epic.awi.de/27384/1/Fie2000b.pdf

Florindo, F., Bohaty, S.M., Erwin, P.S., Richter, C., Roberts, A.P., Whalen, P.A., and Whitehead, J.M., 2003. Magnetobiostratigraphic chronology and palaeoenvironmental history of Cenozoic sequences from ODP sites 1165 and 1166, Prydz Bay, Antarctica. In Florindo, F., Cooper, A.K., and O'Brien, P.E. (Eds.), Antarctic Cenozoic Palaeoenvironments: Geologic Record and Models. Palaeogeography, Palaeoclimatology, Palaeoecology, 198(1-2):69-100. https://doi.org/10.1016/S0031-0182(03)00395-X

Florindo, F., Wilson, G.S., Roberts, A.P., Sagnotti, L., and Verosub, K.L., 2005. Magnetostratigraphic chronology of a late Eocene to early Miocene glacimarine succession from Victoria Land Basin, Ross Sea, Antarctica. Global and Planetary Change, 45(1-3):207-236. https://doi.org/10.1016/j.gloplacha.2004.09.009

Flower, B.P., and Kennett, J.P., 1994. The middle Miocene climatic transition: East Antarctic ice sheet development, deep ocean circulation and global carbon cycling. Palaeogeography, Palaeoclimatology, Palaeoecology, 108(3-4):537-555. https://doi.org/10.1016/0031-0182(94)90251-8

Ford, A.B., and Barrett, P.J., 1975. Basement rocks of the south-central Ross Sea, Site 270, DSDP Leg 28. In Hayes, D.E., Frakes, L.A., et al., Initial Reports of the Deep Sea Drilling Project, 28. Washington DC (U.S. Government Printing Office), 861-868. https://doi.org/10.2973/dsdp.proc.28.131.1975

Foster, G.L., Lear, C.H., and Rae, J.W.B., 2012. The evolution of $p \mathrm{CO}_{2}$, ice volume and climate during the middle Miocene. Earth and Planetary Science Letters, 341-344:243-254.

https://doi.org/10.1016/j.epsl.2012.06.007

Foster, G.L., and Rohling, E.J., 2013. Relationship between sea level and climate forcing by $\mathrm{CO}_{2}$ on geological timescales. Proceedings of the National Academy of Sciences, 110(4):1209-1214. https://doi.org/10.1073/pnas.1216073110

Galeotti, S., DeConto, R., Naish, T., Stocchi, P., Florindo, F., Pagani, M., Barrett, P., et al., 2016. Antarctic Ice Sheet variability across the Eocene-Oligocene boundary climate transition. Science, 352(6281):76-80. https://doi.org/10.1126/science.aab0669

Gasson, E., DeConto, R.M., Pollard, D., and Levy, R.H., 2016. Dynamic Antarctic Ice Sheet during the early to mid-Miocene. Proceedings of the National Academy of Sciences of the United States of America, 113(13):3459-3464. https://doi.org/10.1073/pnas.1516130113

Golledge, N.R., Fogwill, C.J., Mackintosh, A.N., and Buckley, K.M., 2012. Dynamics of the Last Glacial Maximum Antarctic Ice Sheet and its response to ocean forcing. Proceedings of the National Academy of Sciences of the United States of America, 109(40):16052-16056. https://doi.org/10.1073/pnas.1205385109

Golledge, N.R., Levy, R.H., McKay, R.M., Fogwill, C.J., White, D.A., Graham, A.C.C., Smith, J.A., et al., 2013. Glaciology and geological signature of the Last Glacial Maximum Antarctic Ice Sheet. Quaternary Science Reviews, 78:225-247. https://doi.org/10.1016/j.quascirev.2013.08.011

Grützner, J., Rebesco, M.A., Cooper, A.K., Forsberg, C.F., Kryc, K.A., and Wefer, G., 2003. Evidence for orbitally controlled size variations of the East Antarctic Ice Sheet during the late Miocene. Geology, 31(9):777-780. https://doi.org/10.1130/G19574.1

Hall, I.R., McCave, I.N., Shackleton, N.J., Weedon, G.P., and Harris, S.E., 2001. Intensified deep Pacific inflow and ventilation in Pleistocene glacial times. Nature, 412(6849):809-812. https://doi.org/10.1038/35090552

Harland, R., and Pudsey, C.J., 2002. Protoperidiniacean dinoflagellate cyst taxa from the upper Miocene of ODP Leg 178, Antarctic Peninsula. Review of Palaeobotany and Palynology, 120(3-4):263-284. https://doi.org/10.1016/S0034-6667(02)00080-5

Harwood, D.M., and Maruyama, T., 1992. Middle Eocene to Pleistocene diatom biostratigraphy of Southern Ocean sediments from the Kerguelen 
Plateau, Leg 120. In Wise, S.W., Jr., Schlich, R., et al., Proceedings of the Ocean Drilling Program, Scientific Results, 120: College Station, TX (Ocean Drilling Program), 683-733. https://doi.org/10.2973/odp.proc.sr.120.160.1992

Hayes, D.E., Frakes, L.A., et al., 1975. Initial Reports of the Deep Sea Drilling Project, 28: Washington, DC (U.S. Government Printing Office). https://doi.org/10.2973/dsdp.proc.28.1975

Hepp, D.A., Mörz, T., and Grützner, J., 2006. Pliocene glacial cyclicity in a deep-sea sediment drift (Antarctic Peninsula Pacific Margin). Palaeogeography, Palaeoclimatology, Palaeoecology, 231(1-2):181-198. https://doi.org/10.1016/j.palaeo.2005.07.030

Herbert, T.D., Lawrence, K.T., Tzanova, A., Peterson, L.C., Caballero-Gill, R., and Kelly, C.S., 2016. Late Miocene global cooling and the rise of modern ecosystems. Nature Geoscience, 9(11):843-847. https://doi.org/10.1038/ngeo2813

Hinz, K., and Block, M., 1984. Results of geophysical investigations in the Weddell Sea and in the Ross Sea, Antarctica. Proceedings of the 11th World Petroleum Congress, 11(2):79-91.

Hodell, D.A., and Venz-Curtis, K.A., 2006. Late Neogene history of deepwater ventilation in the Southern Ocean. Geochemistry, Geophysics, Geosystems, 7(9). https://doi.org/10.1029/2005GC001211

Holbourn, A., Kuhnt, W., Schulz, M., Flores, J.-A., and Andersen, N., 2007. Orbitally-paced climate evolution during the middle Miocene "Monterey" carbon-isotope excursion. Earth and Planetary Science Letters, 261(3-4):534-550. https://doi.org/10.1016/j.epsl.2007.07.026

Houben, A.J.P., Bijl, P.K., Pross, J., Bohaty, S.M., Passchier, S., Stickley, C.E., Röhl, U., et al., 2013. Reorganization of Southern Ocean plankton ecosystem at the onset of Antarctic glaciation. Science, 340(6130):341-344. https://doi.org/10.1126/science.1223646

Huck, C.E., van de Flierdt, T., Bohaty, S.M., and Hammond, S.J., 2017. Antarctic climate, Southern Ocean circulation patterns, and deep water formation during the Eocene. Paleoceanography, 32(7):674-691. https://doi.org/10.1002/2017PA003135

Huybers, P., 2006. Early Pleistocene glacial cycles and the integrated summer insolation forcing. Science, 313(5786):508-511. https://doi.org/10.1126/science.1125249

Jacobs S.S., Bauer, E.B., Bruchhausen, P.M., Gordon, A.L., Root, T.F., and Rosselot, F.L., 1974. Eltanin Reports: Cruises 47-50, 1971, 52-55, 1972: Hydrographic Stations, Bottom Photographs, Current Measurements, Nephelometer Profiles: Palisades, NY (Lamont-Doherty Geological Observatory, Columbia University), CU 2-74.

Jacobs, S.S., and Giulivi, C.F., 2010. Large multidecadal salinity trends near the Pacific-Antarctic continental margin. Journal of Climate, 23(17):45084524. https://doi.org/10.1175/2010JCLI3284.1

Jacobs, S.S., Giulivi, C.F., and Mele, P.A., 2002. Freshening of the Ross Sea during the late 20th Century. Science, 297(5580):386-389. https://doi.org/10.1126/science.1069574

Jacobs, S.S., Jenkins, A., Giulivi, C.F., and Dutrieux, P., 2011. Stronger ocean circulation and increased melting under Pine Island Glacier ice shelf. Nature Geoscience, 4(8):519-523. https://doi.org/10.1038/ngeo1188

John, C.M., Karner, G.D., Browning, E., Leckie, R.M., Mateo, Z., Carson, B., and Lowery, C., 2011. Timing and magnitude of Miocene eustasy derived from the mixed siliciclastic-carbonate stratigraphic record of the northeastern Australian margin. Earth and Planetary Science Letters, 304(34):455-467. https://doi.org/10.1016/j.epsl.2011.02.013

Johnson, G.C., 2008. Quantifying Antarctic Bottom Water and North Atlantic Deep Water volumes. Journal of Geophysical Research: Oceans, 113(C5):C05027. https://doi.org/10.1029/2007JC004477

Joseph, L.H., Rea, D.K., and van der Pluijm, B.A., 2004. Neogene history of the Deep Western Boundary Current at Rekohu sediment drift, Southwest Pacific (ODP Site 1124). In McCave, I.N., Carter, L., Carter, R.M., and Hayward, B.W. (Eds.), Cenozoic Oceanographic Evolution of the Southwest Pacific Gateway, ODP Leg 181. Marine Geology, 205(1-4):185-206. https://doi.org/10.1016/S0025-3227(04)00023-4
Joughin, I., Alley, R.B., and Holland, D.M., 2012. Ice-sheet response to oceanic forcing. Science, 338(6111):1172-1176. https://doi.org/10.1126/science.1226481

Karner, G.D., Studinger, M., and Bell, R.E., 2005. Gravity anomalies of sedimentary basins and their mechanical implications: application to the Ross Sea basins, West Antarctica. Earth and Planetary Science Letters, 235(34):577-596. https://doi.org/10.1016/j.epsl.2005.04.016

Kennett, J.P., 1977. Cenozoic evolution of Antarctic glaciation, the circumAntarctic Ocean, and their impact on global paleoceanography. Journal of Geophysical Research: Oceans and Atmospheres, 82(27):3843-3860. https://doi.org/10.1029/JC082i027p03843

Kennett, J.P., and Barker, P.F., 1990. Latest Cretaceous to Cenozoic climate and oceanographic developments in the Weddell Sea, Antarctica: an oceandrilling perspective. In Barker, P.F., Kennett, J.P., et al., Proceedings of the Ocean Drilling Program, Scientific Results, 113: College Station, TX (Ocean Drilling Program), 937-960. https://doi.org/10.2973/odp.proc.sr.113.195.1990

Kim, S., De Santis, L., Hong, J.K., Cottlerle, D., Petronio, L., Colizza, E., Kim, Y.-G., et al., 2018. Seismic stratigraphy of the Central Basin in northwestern Ross Sea slope and rise, Antarctica: clues to the late Cenozoic icesheet dynamics and bottom-current activity. Marine Geology, 395:363379. https://doi.org/10.1016/j.margeo.2017.10.013

Kingslake, J., Scherer, R.P., Albrecht, T., Coenen, J., Powell, R.D., Reese, R., Stansell, N.D., Tulaczyk, S., Wearing, M.G., and Whitehouse, P.L., 2018. Extensive retreat and re-advance of the West Antarctic Ice Sheet during the Holocene. Nature, 558(7710):430-434. https://doi.org/10.1038/s41586-018-0208-x

Kominz, M.A., Browning, J.V., Miller, K.G., Sugarman, P.J., Misintseva, S., and Scotese, C.R., 2008. Late Cretaceous to Miocene sea-level estimates from the New Jersey and Delaware coastal plain coreholes: an error analysis. Basin Research, 20(2):211-226. https://doi.org/10.1111/j.1365-2117.2008.00354.x

Kopp, R.E., Simons, F.J., Mitrovica, J.X., Maloof, A.C., and Oppenheimer, M., 2009. Probabilistic assessment of sea level during the last interglacial stage. Nature, 462(7275):863-867. https://doi.org/10.1038/nature08686

Leckie, R.M., and Webb, P.-N., 1986. Late Paleogene and early Neogene foraminifers of Deep Sea Drilling Project Site 270, Ross Sea, Antarctica. In Kennett, J. P., von der Borch, C.C., et al., Initial Reports of the Deep Sea Drilling Project, 90: Washington, DC (U.S. Government Printing Office), 1093-1142. https://doi.org/10.2973/dsdp.proc.90.124.1986

Levy, R., Harwood, D., Florindo, F., Sangiorgi, F., Tripati, R., von Eynatten, H., Gasson, E., et al., 2016. Antarctic Ice Sheet sensitivity to atmospheric $\mathrm{CO}_{2}$ variations in the early to mid-Miocene. Proceedings of the National Academy of Sciences of the United States of America, 113(13):3453-3458. https://doi.org/10.1073/pnas.1516030113

Lewis, A.R., Marchant, D.R., Ashworth, A.C., Hedenäs, L., Hemming, S.R., Johnson, J.V., Leng, M.J., et al., 2008. Mid-Miocene cooling and the extinction of tundra in continental Antarctica. Proceedings of the National Academy of Sciences of the United States of America, 105(31):1067610680. https://doi.org/10.1073/pnas.0802501105

Lewis, A.R., Marchant, D.R., Kowalewski, D.E., Baldwin, S.L., and Webb, L.E., 2006. The age and origin of the Labyrinth, western Dry Valleys, Antarctica: evidence for extensive middle Miocene subglacial floods and freshwater discharge to the Southern Ocean. Geology, 34(7):513-516. https://doi.org/10.1130/G22145.1

Licht, K.J., Hennessy, A.J., and Welke, B.M., 2014. The U-Pb detrital zircon signature of West Antarctic ice stream tills in the Ross Embayment, with implications for Last Glacial Maximum ice flow reconstructions. Antarctic Science, 26(6):687-697. https://doi.org/10.1017/S0954102014000315

Licht, K.J., Lederer, J.R., and Swope, R.J., 2005. Provenance of LGM glacial till (sand fraction) across the Ross Embayment, Antarctica. Quaternary Science Reviews, 24(12-13):1499-1520. https://doi.org/10.1016/j.quascirev.2004.10.017 
Lindeque, A., Gohl, K., Henrys, S., Wobbe, F., and Davy, B., 2016. Seismic stratigraphy along the Amundsen Sea to Ross Sea continental rise: a cross-regional record of pre-glacial to glacial processes of the West Antarctic margin. Palaeogeography, Palaeoclimatology, Palaeoecology, 443:183-202. https://doi.org/10.1016/j.palaeo.2015.11.017

Lisiecki, L.E., and Raymo, M.E., 2005. A Pliocene-Pleistocene stack of 57 globally distributed benthic $\delta^{18} \mathrm{O}$ records. Paleoceanography, 20(1):PA1003. https://doi.org/10.1029/2004PA001071

Lucchi, R.G., and Rebesco, M., 2007. Glacial contourites on the Antarctic Peninsula margin: insight for palaeoenvironmental and palaeoclimatic conditions. Geological Society Special Publication, 276(1):111-127. https://doi.org/10.1144/GSL.SP.2007.276.01.06

Luyendyk, B.P., Sorlien, C.C., Wilson, D.S., Bartek, L.R., and Siddoway, C.S., 2001. Structural and tectonic evolution of the Ross Sea rift in the Cape Colbeck region, Eastern Ross Sea, Antarctica. Tectonics, 20(6):933-958. https://doi.org/10.1029/2000TC001260

Masson-Delmotte, V., Schulz, M., Abe-Ouchi, A., Beer, J., Ganopolski, A., González Rouco, J.F., Jansen, E., et al., 2013. Information from paleoclimate archives. In Stocker, T.F., Qin, D., Plattner, G.-K., Tignor, M., Allen, S.K., Boschung, J., Nauels, A., Xia, Y., Bex, V., and Midgley, P.M. (Eds.), Climate Change 2013: The Physical Science Basis. Contribution of Working Group I to the Fifth Assessment Report of the Intergovernmental Panel on Climate Change: Cambridge, United Kingdom (Cambridge University Press), 383-464. http://www.climatechange2013.org/images/report/WG1AR5_Chapter05_FINAL.pdf

McKay, R., Browne, G., Carter, L., Cowan, E., Dunbar, G., Krissek, L., Naish, T., et al., 2009. The stratigraphic signature of the late Cenozoic Antarctic Ice Sheets in the Ross Embayment. Geological Society of America Bulletin, 121(11-12):1537-1561. https://doi.org/10.1130/B26540.1

McKay, R.M., De Santis, L., and Kulhanek, D.K., 2017. Expedition 374 Scientific Prospectus: Ross Sea West Antarctic Ice Sheet History. International Ocean Discovery Program. https://doi.org/10.14379/iodp.sp.374.2017

McKay, R., Naish, T., Carter, L., Riesselman, C., Dunbar, R., Sjunneskog, C., Winter, D., et al., 2012a. Antarctic and Southern Ocean influences on late Pliocene global cooling. Proceedings of the National Academy of Sciences of the United States of America, 109(17):6423-6428. https://doi.org/10.1073/pnas.1112248109

McKay, R., Naish, T., Powell, R., Barrett, P., Scherer, R., Talarico, F., Kyle, P., et al., 2012b. Pleistocene variability of Antarctic ice sheet extent in the Ross Embayment. Quaternary Science Reviews, 34:93-112. https://doi.org/10.1016/j.quascirev.2011.12.012

McKay, R.M., De Santis, L., Kulhanek, D.K., Ash, J.L., Beny, F., Browne, I.M., Cortese, G., Cordeiro de Sousa, I.M., Dodd, J.P., Esper, O.M., Gales, J.A., Harwood, D.M., Ishino, S., Keisling, B.A., Kim, S., Kim, S., Laberg, J.S., Leckie, R.M., Müller, J., Patterson, M.O., Romans, B.W., Romero, O.E., Sangiorgi, F., Seki, O., Shevenell, A.E., Singh, S.M., Sugisaki, S.T., van de Flierdt, T., van Peer, T.E., Xiao, W., and Xiong, Z., 2019a. Site U1522. In McKay, R.M., De Santis, L., Kulhanek, D.K., and the Expedition 374 Scientists, Ross Sea West Antarctic Ice Sheet History. Proceedings of the International Ocean Discovery Program, 374: College Station, TX (International Ocean Discovery Program). https://doi.org/10.14379/iodp.proc.374.104.2019

McKay, R.M., De Santis, L., Kulhanek, D.K., Ash, J.L., Beny, F., Browne, I.M., Cortese, G., Cordeiro de Sousa, I.M., Dodd, J.P., Esper, O.M., Gales, J.A., Harwood, D.M., Ishino, S., Keisling, B.A., Kim, S., Kim, S., Laberg, J.S., Leckie, R.M., Müller, J., Patterson, M.O., Romans, B.W., Romero, O.E., Sangiorgi, F., Seki, O., Shevenell, A.E., Singh, S.M., Sugisaki, S.T., van de Flierdt, T., van Peer, T.E., Xiao, W., and Xiong, Z., 2019b. Site U1523. In McKay, R.M., De Santis, L., Kulhanek, D.K., and the Expedition 374 Scientists, Ross Sea West Antarctic Ice Sheet History. Proceedings of the International Ocean Discovery Program, 374: College Station, TX (International Ocean Discovery Program). https://doi.org/10.14379/iodp.proc.374.105.2019

McKay, R.M., De Santis, L., Kulhanek, D.K., Ash, J.L., Beny, F., Browne, I.M., Cortese, G., Cordeiro de Sousa, I.M., Dodd, J.P., Esper, O.M., Gales, J.A., Harwood, D.M., Ishino, S., Keisling, B.A., Kim, S., Kim, S., Laberg, J.S.,
Leckie, R.M., Müller, J., Patterson, M.O., Romans, B.W., Romero, O.E., Sangiorgi, F., Seki, O., Shevenell, A.E., Singh, S.M., Sugisaki, S.T., van de Flierdt, T., van Peer, T.E., Xiao, W., and Xiong, Z., 2019c. Site U1524. In McKay, R.M., De Santis, L., Kulhanek, D.K., and the Expedition 374 Scientists, Ross Sea West Antarctic Ice Sheet History. Proceedings of the International Ocean Discovery Program, 374: College Station, TX (International Ocean Discovery Program). https://doi.org/10.14379/iodp.proc.374.106.2019

McKay, R.M., De Santis, L., Kulhanek, D.K., Ash, J.L., Beny, F., Browne, I.M., Cortese, G., Cordeiro de Sousa, I.M., Dodd, J.P., Esper, O.M., Gales, J.A., Harwood, D.M., Ishino, S., Keisling, B.A., Kim, S., Kim, S., Laberg, J.S., Leckie, R.M., Müller, J., Patterson, M.O., Romans, B.W., Romero, O.E., Sangiorgi, F., Seki, O., Shevenell, A.E., Singh, S.M., Sugisaki, S.T., van de Flierdt, T., van Peer, T.E., Xiao, W., and Xiong, Z., 2019d. Site U1525. In McKay, R.M., De Santis, L., Kulhanek, D.K., and the Expedition 374 Scientists, Ross Sea West Antarctic Ice Sheet History. Proceedings of the International Ocean Discovery Program, 374: College Station, TX (International Ocean Discovery Program). https://doi.org/10.14379/iodp.proc.374.107.2019

Meinshausen, M., Smith, S.J., Calvin, K., Daniel, J.S., Kainuma, M.L.T., Lamarque, J.-F., Matsumoto, K., et al., 2011. The RCP greenhouse gas concentrations and their extensions from 1765 to 2300. Climatic Change, 109:213-241. https://doi.org/10.1007/s10584-011-0156-z

Mercer, J.H., 1978. West Antarctic Ice Sheet and $\mathrm{CO}_{2}$ greenhouse effect: a threat of disaster. Nature, 271(5643):321-325. https://doi.org/10.1038/271321a0

Miller, K.G., Kominz, M.A., Browning, J.V., Wright, J.D., Mountain, G.S., Katz, M.E., Sugarman, P.J., Cramer, B.S., Christie-Blick, N., and Pekar, S.F., 2005. The Phanerozoic record of global sea-level change. Science, 310(5752):1293-1298. https://doi.org/10.1126/science.1116412

Miller, K.G., Mountain, G.S., Wright, J.D., and Browning, J.V., 2011. A 180million-year record of sea level and ice volume variations from continental margin and deep-sea isotopic records. Oceanography, 24(2):40-53. https://doi.org/10.5670/oceanog.2011.26

Miller, K.G., Wright, J.D., Browning, J.V., Kulpecz, A., Kominz, M., Naish, T.R., Cramer, B.S., Rosenthal, Y., Peltier, W.R., and Sosdian, S., 2012. High tide of the warm Pliocene: implications of global sea level for Antarctic deglaciation. Geology, 40(5):407-410. https://doi.org/10.1130/G32869.1

Naish, T.R., Powell, R., Levy, R., Wilson, G., Scherer, R., Talarico, F., Krissek, L., et al., 2009. Obliquity-paced Pliocene West Antarctic Ice Sheet oscillations. Nature, 458(7236):322-329. https://doi.org/10.1038/nature07867

Naish, T.R., and Wilson, G.S., 2009. Constraints on the amplitude of mid-Pliocene (3.6-2.4 Ma) eustatic sea-level fluctuations from the New Zealand shallow-marine sediment record. Philosophical Transactions of the Royal Society, A: Mathematical, Physical \& Engineering Sciences, 367(1886):169-187. https://doi.org/10.1098/rsta.2008.0223

Naish, T.R., Woolfe, K.J., Barrett, P.J., Wilson, G.S., Atkins, C., Bohaty, S.M., Bücker, C.J., et al., 2001. Orbitally induced oscillations in the East Antarctic Ice Sheet at the Oligocene/Miocene boundary. Nature, 413(6857):719-723. https://doi.org/10.1038/35099534

Newkirk, D., and Martin, E.E., 2009. Circulation through the Central American Seaway during the Miocene carbonate crash. Geology, 37(1):87-90. https://doi.org/10.1130/G25193A.1

Ohneiser, C., Florindo, F., Stocchi, P., Roberts, A.P., DeConto, R.M., and Pollard, D., 2015. Antarctic glacio-eustatic contributions to late Miocene Mediterranean desiccation and reflooding. Nature Communications, 6(1):8765. https://doi.org/10.1038/ncomms9765

Orsi, A.H., and Wiederwohl, C.L., 2009. A recount of Ross Sea waters. Deep Sea Research, Part II: Topical Studies in Oceanography, 56(13-14):778795. https://doi.org/10.1016/j.dsr2.2008.10.033

Orsi, A.H., Johnson, G.C., and Bullister, J.L., 1999. Circulation, mixing, and production of Antarctic bottom water. Progress in Oceanography, 43(1):55-109. https://doi.org/10.1016/S0079-6611(99)00004-X 
Padman, L., and Fricker, H.A., 2005. Tides on the Ross Ice Shelf observed with ICESat. Geophysical Research Letters, 32(14):L14503. https://doi.org/10.1029/2005GL023214

Pagani, M., Zachos, J.C., Freeman, K.H., Tipple, B., and Bohaty, S., 2005. Marked decline in atmospheric carbon dioxide concentrations during the Paleogene. Science, 309(5734):600-603. https://doi.org/10.1126/science.1110063

Pälike, H., Lyle, M.W., Nishi, H., Raffi, I., Ridgwell, A., Gamage, K., Klaus, A., et al., 2012. A Cenozoic record of the equatorial Pacific carbonate compensation depth. Nature, 488(7413):609-614. https://doi.org/10.1038/nature11360

Passchier, S., Browne, G., Field, B., Fielding, C.R., Krissek, L.A., Panter, K., Pekar, S.F., and ANDRILL-SMS Science Team, 2011. Early and middle Miocene Antarctic glacial history from the sedimentary facies distribution in the AND-2A drill hole, Ross Sea, Antarctica. Geological Society of America Bulletin, 123(11-12):2352-2365.

https://doi.org/10.1130/B30334.1

Patterson, M.O., and Ishman, S.E., 2012. Neogene benthic foraminiferal assemblages and paleoenvironmental record for McMurdo Sound, Antarctica. Geosphere, 8(6):1331-1341. https://doi.org/10.1130/GES00771.1

Patterson, M.O., McKay, R., Naish, T., Escutia, C., Jimenez-Espejo, F.J., Raymo, M.E., Meyers, S.R., Tauxe, L., Brinkhuis, H., and IODP Expedition 318 Scientists, 2014. Orbital forcing of the East Antarctic ice sheet during the Pliocene and early Pleistocene. Nature Geoscience, 7:841-847. https://doi.org/10.1038/ngeo2273

Perotti, M., Andreucci, B., Talarico, F., Zattin, M., and Langone, A., 2017. Multianalytical provenance analysis of Eastern Ross Sea LGM till sediments (Antarctica): petrography, geochronology, and thermochronology detrital data. Geochemistry, Geophysics, Geosystems, 18(6):2275-2304. https://doi.org/10.1002/2016GC006728

Pierce, E.L., van de Flierdt, T., Williams, T., Hemming, S.R., Cook, C., and Passchier, S., 2017. Evidence for a dynamic East Antarctic ice sheet during the mid-Miocene climate transition. Earth and Planetary Science Letters, 478:1-13. https://doi.org/10.1016/j.epsl.2017.08.011

Pollard, D., and DeConto, R.M, 2009. Modelling West Antarctic Ice Sheet growth and collapse through the past five million years. Nature, 458(7236):329-332. https://doi.org/10.1038/nature07809

Powell, R.D., and Cooper, J.M., 2002. A glacial sequence stratigraphic model for temperate, glaciated continental shelves. In Dowdeswell, J.A., and Ó'Cofaigh, C. (Eds.), Glacier-Influenced Sedimentation on High-Latitude Continental Margins. Geological Society Special Publication, 203:215244. https://doi.org/10.1144/GSL.SP.2002.203.01.12

Prins, M.A., Bouwer, L.M., Beets, C.J., Troelstra, S.R., Weltje, G.J., Kruk, R.W., Kuijpers, A., and Vroon, P.Z., 2002. Ocean circulation and iceberg discharge in the glacial North Atlantic: inferences from unmixing of sediment size distributions. Geology, 30(6):555-558. https://doi.org/10.1130/0091-7613(2002)030<0555:OCAIDI $>2.0 . \mathrm{CO} ; 2$

Pritchard, H.D., Ligtenberg, S.R.M., Fricker, H.A., Vaughan, D.G., van den Broeke, M.R., and Padman, L., 2012. Antarctic ice-sheet loss driven by basal melting of ice shelves. Nature, 484(7395):502-505. https://doi.org/10.1038/nature10968

Purkey, S.G., and Johnson, G.C., 2010. Warming of global abyssal and deep Southern Ocean waters between the 1990s and 2000s: contributions to global heat and sea level rise budgets. Journal of Climate, 23(23):63366351. https://doi.org/10.1175/2010JCLI3682.1

Purkey, S.G., and Johnson, G.C., 2012. Global contraction of Antarctic Bottom Water between the 1980s and 2000s. Journal of Climate, 25(17):5830-5844. https://doi.org/10.1175/JCLI-D-11-00612.1

Raymo, M.E., Lisiecki, L.E., and Nisancioglu, K.H., 2006. Plio-Pleistocene ice volume, Antarctic climate, and the global $\delta^{18} \mathrm{O}$ record. Science, 313(5786):492-495. https://doi.org/10.1126/science.1123296

Raymo, M.E., Mitrovica, J.X., O'Leary, M.J., DeConto, R.M., and Hearty, P.J., 2011. Departures from eustasy in Pliocene sea-level records. Nature Geoscience, 4(5):328-332. https://doi.org/10.1038/ngeo1118
Rebesco, M., Camerlenghi, A., Geletti, R., and Canals, M., 2006. Margin architecture reveals the transition to the modern Antarctic Ice Sheet (AIS) ca. 3 Ma. Geology, 34(4):301-304. https://doi.org/10.1130/G22000.1

Rignot, E., and Jacobs, S.S., 2002. Rapid bottom melting widespread near Antarctic ice sheet grounding lines. Science, 296(5575):2020-2023. https://doi.org/10.1126/science.1070942

Sangiorgi, F., Bijl, P.K., Passchier, S., Salzmann, U., Schouten, S., McKay, R., Cody, R.D., et al., 2018. Southern Ocean warming and Wilkes Land ice sheet retreat during the mid-Miocene. Nature Communications, 9(1):317. https://doi.org/10.1038/s41467-017-02609-7

Scher, H.D., and Martin, E.E., 2006. Timing and climatic consequences of the opening of Drake Passage. Science, 312(5772):428-430. https://doi.org/10.1126/science.1120044

Scherer, R.P., Aldahan, A., Tulaczyk, S., Possnert, G., Engelhardt, H., and Kamb, B., 1998. Pleistocene collapse of the West Antarctic Ice Sheet. Science, 281(5373):82-85. https://doi.org/10.1126/science.281.5373.82

Scherer, R.P., Bohaty, S.M., Dunbar, R.B., Esper, O., Flores, J.-A., Gersonde, R., Harwood, D.M., Roberts, A.P., and Taviani, M., 2008. Antarctic records of precession-paced insolation-driven warming during early Pleistocene marine isotope Stage 31. Geophysical Research Letters, 35(3):L03505. https://doi.org/10.1029/2007GL032254

Shepherd, A., Ivins, E.R., Geruo, A., Barletta, V.R., Bentley, M.J., Bettadpur, S., Briggs, K.H., et al., 2012. A reconciled estimate of ice-sheet mass balance. Science, 338(6111):1183-1189. https://doi.org/10.1126/science.1228102

Shevenell, A.E., Ingalls, A.E., Domack, E.W., and Kelly, C., 2011. Holocene Southern Ocean surface temperature variability west of the Antarctic Peninsula. Nature, 470(7333):250-254. https://doi.org/10.1038/nature09751

Shevenell, A.E., Kennett, J.P., and Lea, D.W., 2004. Middle Miocene Southern Ocean cooling and Antarctic cryosphere expansion. Science, 305(5691):1766-1770. https://doi.org/10.1126/science.1100061

Shevenell, A.E., Kennett, J.P., and Lea, D.W., 2008. Middle Miocene ice sheet dynamics, deep-sea temperatures, and carbon cycling: a Southern Ocean perspective. Geochemistry, Geophysics, Geosystems, 9(2):Q02006. https://doi.org/10.1029/2007GC001736

Shipboard Scientific Party, 1975a. Introduction. In Hayes, D.E., Frakes, L.A., et al., Initial Reports of the Deep Sea Drilling Project, 28: Washington, DC (U.S. Government Printing Office), 5-18. https://doi.org/10.2973/dsdp.proc.28.101.1975

Shipboard Scientific Party, 1975b. Sites 270, 271, 272. In Hayes, D.E., Frakes, L.A., et al., Initial Reports of the Deep Sea Drilling Project, 28: Washington, DC (U.S. Government Printing Office), 211-334. https://doi.org/10.2973/dsdp.proc.28.108.1975

Shipboard Scientific Party, 2001. Leg 189 summary. In Exon, N.F., Kennett, J.P., Malone, M.J., et al., Proceedings of the Ocean Drilling Program, Initial Reports, 189: College Station, TX (Ocean Drilling Program), 1-98. https://doi.org/10.2973/odp.proc.ir.189.101.2001

Siddoway, C.S., Baldwin, S.L., Fitzgerald, P.G., Fanning, C.M., and Luyendyk, B.P., 2004. Ross Sea mylonites and the timing of intracontinental extension within the West Antarctic rift system. Geology, 32(1):57-60. https://doi.org/10.1130/G20005.1

Simões Pereira, P., van de Flierdt, T., Hemming, S.R., Hammond, S.J., Kuhn, G., Brachfeld, S., Doherty, C., and Hillenbrand, C.-D., 2018. Geochemical fingerprints of glacially eroded bedrock from West Antarctica: detrital thermochronology, radiogenic isotope systematics and trace element geochemistry in late Holocene glacial-marine sediments. Earth-Science Reviews, 182:204-232. https://doi.org/10.1016/j.earscirev.2018.04.011

Sorlien, C.C., Luyendyk, B.P., Wilson, D.S., Decesari, R.C., Bartek, L.R., and Diebold, J.B., 2007. Oligocene development of the West Antarctic Ice Sheet recorded in eastern Ross Sea strata. Geology, 35(5):467-470. https://doi.org/10.1130/G23387A.1

Talarico, F.M., McKay, R.M., Powell, R.D., Sandroni, S., and Naish, T., 2012. Late Cenozoic oscillations of Antarctic Ice Sheets revealed by provenance of basement clasts and grain detrital modes in ANDRILL core AND-1B. Global and Planetary Change, 96-97:23-40. https://doi.org/10.1016/j.gloplacha.2009.12.002 
Tauxe, L., Stickley, C.E., Sugisaki, S., Bijl, P.K., Bohaty, S.M., Brinkhuis, H., Escutia, C., et al., 2012. Chronostratigraphic framework for the IODP Expedition 318 cores from the Wilkes Land Margin: constraints for paleoceanographic reconstruction. Paleoceanography, 27(2):PA2214. https://doi.org/10.1029/2012PA002308

Ten Brink, U.S., Schneider, C., and Johnson, A.H., 1995. Morphology and stratal geometry of the Antarctic continental shelf: insights from models. In Cooper, A.K., Barker, P.F., and Brancolini, G. (Eds.), Antarctic Research Series (Volume 68): Geology and Seismic Stratigraphy of the Antarctic Margin: Washington, DC (American Geophysical Union), 1-24. https://doi.org/10.1029/AR068p0001

Theissen, K.M., Dunbar, R.B., Cooper, A.K, Mucciarone, D.A., and Hoffmann, D., 2003. The Pleistocene evolution of the East Antarctic Ice Sheet in the Prydz bay region: stable isotopic evidence from ODP Site 1167. Global and Planetary Change, 39(3-4):227-256. https://doi.org/10.1016/S0921-8181(03)00118-8

Thomas, R.H., and Bentley, C.R., 1978. A model for Holocene retreat of the West Antarctic Ice Sheet. Quaternary Research,10(02):150-170. https://doi.org/10.1016/0033-5894(78)90098-4

Tzedakis, P.C., Crucifix, M., Mitsui, T., and Wolff, E.W., 2017. A simple rule to determine which insolation cycles lead to interglacials. Nature, 542(7642):427-432. https://doi.org/10.1038/nature21364

van de Flierdt, T., Frank, M., Halliday, A.N., Hein, J.R., Hattendorf, B., Günther, D., and Kubik, P.W., 2004. Deep and bottom water export from the Southern Ocean to the Pacific over the past 38 million years. Paleoceanography, 19(1):PA1020. https://doi.org/10.1029/2003PA000923

Villa, G., Lupi, C., Cobianchi, M., Florindo, F., and Pekar, S.F., 2008. A Pleistocene warming event at $1 \mathrm{Ma}$ in Prydz Bay, East Antarctica: evidence from ODP Site 1165. Palaeogeography, Palaeoclimatology, Palaeoecology, 260(1-2):230-244. https://doi.org/10.1016/j.palaeo.2007.08.017

Vincent, E., and Berger, W.H., 1985. Carbon dioxide and polar cooling in the Miocene: the Monterey Hypothesis. In Sundquist, E.T., and Broecker, W.S. (Eds.), The Carbon Cycle and Atmospheric $\mathrm{CO}_{2}$ : Natural Variations Archean to Present. Geophysical Monograph, 32:455-468. https://doi.org/10.1029/GM032p0455

Warny, S., Askin, R.A., Hannah, M.J., Mohr, B.A.R., Raine, J.I., Harwood, D.M., Florindo, F., and the SMS Science Team, 2009. Palynomorphs from a sediment core reveal a sudden remarkably warm Antarctica during the middle Miocene. Geology, 37(10):955-958. https://doi.org/10.1130/G30139A.1

Weertman, J., 1974. Stability of the junction between an ice sheet and an ice shelf. Journal of Glaciology, 13(67):3-11. https://doi.org/10.3189/S0022143000023327

Whitworth, T., III, Orsi, A.H., Kim, S.-J., Nowlin, W.D., Jr., and Locarnini, R.A., 1995. Water masses and mixing near the Antarctic slope front. In
Jacobs, S.S., and Weiss, R.F. (Eds.), Antarctic Research Series (Volume 75): Ocean, Ice, and Atmosphere: Interactions at the Antarctic Continental Margin: Washington, DC (American Geophysical Union), 1-27. http://onlinelibrary.wiley.com/doi/10.1029/AR075p0001/summary

Wilch, T.I., McIntosh, W.C., and Dunbar, N.W., 1999. Late Quaternary volcanic activity in Marie Byrd Land: potential ${ }^{40} \mathrm{Ar} /{ }^{39} \mathrm{Ar}$-dated time horizons in West Antarctic ice and marine cores. Geological Society of America Bulletin, 111(10):1563-1580. https://doi.org/10.1130/00167606(1999)111<1563:LQVAIM>2.3.CO;2

Williams, T., and Handwerger, D., 2005. A high-resolution record of early Miocene Antarctic glacial history from ODP Site 1165, Prydz Bay. Paleoceanography, 20(2):PA2017. https://doi.org/10.1029/2004PA001067

Wilson, D.S., and Luyendyk, B.P., 2009. West Antarctic paleotopography estimated at the Eocene-Oligocene climate transition. Geophysical Research Letters, 36(16):L16302. https://doi.org/10.1029/2009GL039297

Wilson, D.S., Pollard, D., DeConto, R.M., Jamieson, S.S.R., and Luyendyk, B.P., 2013. Initiation of the West Antarctic Ice Sheet and estimates of total Antarctic ice volume in the earliest Oligocene. Geophysical Research Letters, 40(16):4305-4309. https://doi.org/10.1002/grl.50797

Wilson, G.S., Levy, R.H., Naish, T.R., Powell, R.D., Florindo, F., Ohneiser, C., Sagnotti, L., et al., 2012. Neogene tectonic and climatic evolution of the Western Ross Sea, Antarctica-chronology of events from the AND-1B drill hole. Global and Planetary Change, 96-97:189-203. https://doi.org/10.1016/j.gloplacha.2012.05.019

Woodruff, F., and Savin, S.M., 1985. $\delta^{13} \mathrm{C}$ values of Miocene Pacific benthic foraminifera: correlations with sea level and biological productivity. Geology, 13(2):119-122. https://doi.org/10.1130/0091-7613(1985)13<119:CVOMPB>2.0.CO; 2

Wright, J.D., Miller, K.G., and Fairbanks, R.G., 1991. Evolution of modern deepwater circulation: evidence from the late Miocene Southern Ocean. Paleoceanography, 6(2):275-290. https://doi.org/10.1029/90PA02498

You, Y., Huber, M., Müller, R.D., Poulsen, C.J., and Ribbe, J., 2009. Simulation of the Middle Miocene Climate Optimum. Geophysical Research Letters, 36(4):L04702. https://doi.org/10.1029/2008GL036571

Zachos, J., Pagani, M., Sloan, L., Thomas, E., and Billups, K., 2001. Trends, rhythms, and aberrations in global climate $65 \mathrm{Ma}$ to present. Science, 292(5517):686-693. https://doi.org/10.1126/science.1059412

Zachos, J.C., Dickens, G.R., and Zeebe, R.E., 2008. An early Cenozoic perspective on greenhouse warming and carbon-cycle dynamics. Nature, 451(7176):279-283. https://doi.org/10.1038/nature06588

Zachos, J.C., Flower, B.P., and Paul, H., 1997. Orbitally paced climate oscillations across the Oligocene/Miocene boundary. Nature, 388(6642):567570. https://doi.org/10.1038/41528 